Ground-Water Data-Collection Protocols and Procedures for the National Water-Quality Assessment Program:

Collection, Documentation, and Compilation of

Required Site, Well, Subsurface, and

Landscape Data for Wells

Water-Resources Investigations Report 98-4107

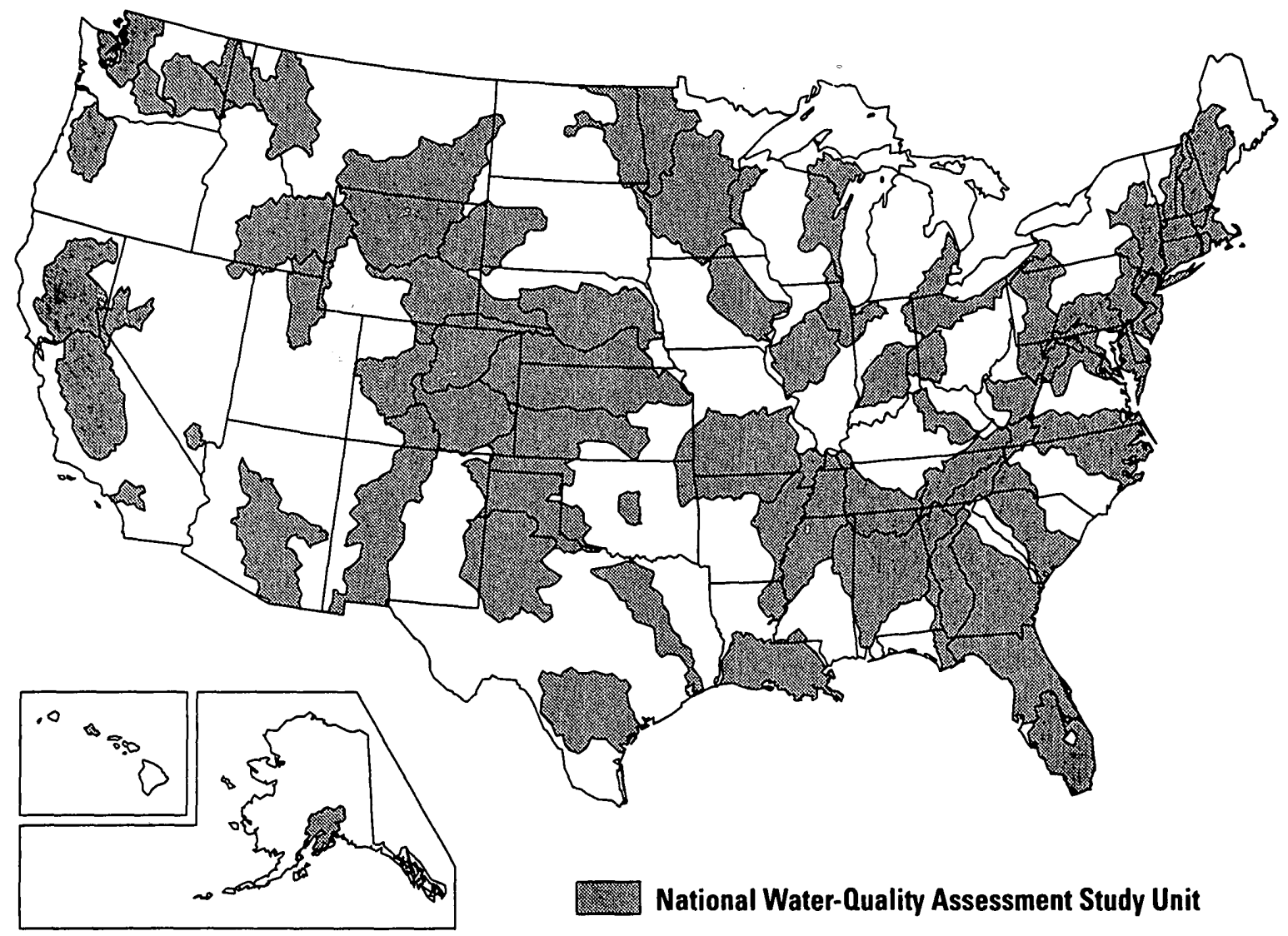

NATIONAL WATER-QUALITY ASSESSMENT PROGRAM 


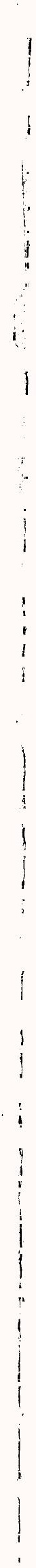




\section{Ground-Water Data-Collection Protocols and Procedures for the National Water-Quality Assessment Program: Collection, Documentation, and Compilation of Required Site, Well, Subsurface, and Landscape Data for Wells}

by Michael T. Koterba

Water-Resources Investigations Report 98-4107 


\section{U.S. Department of the Interior}

BRUCE BABBITT, Secretary

\section{U.S. Geological Survey}

Thomas J. Casadevall, Acting Director

The use of trade, product, or firm names in this report is for descriptive purposes only and does not imply endorsement by the U.S. Geological Survey.

For additional information contact:

\section{District Chief}

U.S. Geological Survey, WRD

8987 Yellow Brick Road

Baltimore, MD 21237

Copies of this report can be purchased from:

U.S. Geological Survey

Branch of Information Services

Box 25286

Denver, CO 80225-0286 


\section{FOREWORD}

The mission of the U.S. Geological Survey (USGS) is to assess the quantity and quality of the earth resources of the Nation and to provide information that will assist resource managers and policymakers at Federal, State, and local levels in making sound decisions. Assessment of water-quality conditions and trends is an important part of this overall mission.

One of the greatest challenges faced by waterresources scientists is acquiring reliable information that will guide the use and protection of the Nation's water resources. That challenge is being addressed by Federal, State, interstate, and local water-resource agencies and by many academic institutions. These organizations are collecting water-quality data for a host of purposes that include: compliance with permits and water-supply standards; development of remediation plans for specific contamination problems; operational decisions on industrial, wastewater, or watersupply facilities; and research on factors that affect water quality. An additional need for water-quality information is to provide a basis on which regionaland national-level policy decisions can be based. Wise decisions must be based on sound information. As a society we need to know whether certain types of water-quality problems are isolated or ubiquitous, whether there are significant differences in conditions among regions, whether the conditions are changing over time, and why these conditions change from place to place and over time. The information can be used to help determine the efficacy of existing waterquality policies and to help analysts determine the need for and likely consequences of new policies.

To address these needs, the U.S. Congress appropriated funds in 1986 for the USGS to begin a pilot program in seven project areas to develop and refine the National Water-Quality Assessment (NAWQA) Program. In 1991, the USGS began full implementation of the program. The NAWQA Program builds upon an existing base of water-quality studies of the USGS, as well as those of other Federal, State, and local agencies. The objectives of the NAWQA Program are to:

- Describe current water-quality conditions for a large part of the Nation's freshwater streams, rivers, and aquifers.
- Describe how water quality is changing over time.

- Improve understanding of the primary natural and human factors that affect water-quality conditions.

This information will help support the development and evaluation of management, regulatory, and monitoring decisions by other Federal, State, and local agencies to protect, use, and enhance water resources.

The goals of the NAWQA Program are being achieved through ongoing and proposed investigations of 60 of the Nation's most important river basins and aquifer systems, which are referred to as study units. These study units are distributed throughout the Nation and cover a diversity of hydrogeologic settings. More than two-thirds of the Nation's freshwater use occurs within the 60 study units and more than twothirds of the people served by public water-supply systems live within their boundaries.

National synthesis of data analysis, based on aggregation of comparable information obtained from the study units, is a major component of the program. This effort focuses on selected water-quality topics using nationally consistent information. Comparative studies will explain differences and similarities in observed water-quality conditions among study areas and will identify changes and trends and their causes. The first topics addressed by the national synthesis are pesticides, nutrients, volatile organic compounds, and aquatic biology. Discussions on these and other waterquality topics will be published in periodic summaries of the quality of the Nation's ground and surface water as the information becomes available.

This report is an element of the comprehensive body of information developed as part of the NAWQA Program. The program depends heavily on the advice, cooperation, and information from many Federal, State, interstate, Tribal, and local agencies and the public. The assistance and suggestions of all are greatly appreciated.

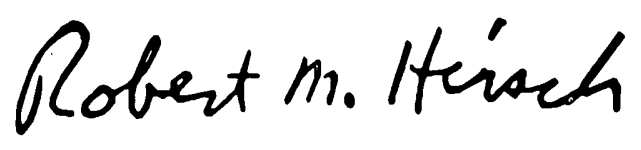

Robert M. Hirsch Chief Hydrologist 
,

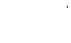

$+2$




\section{CONTENTS}

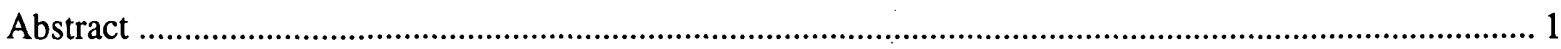

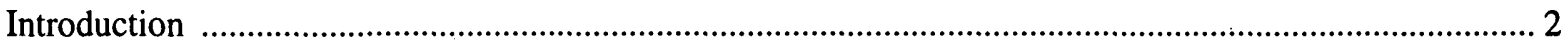

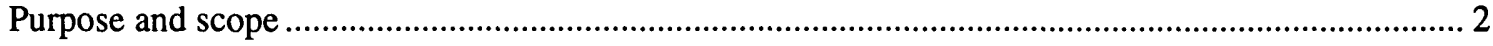

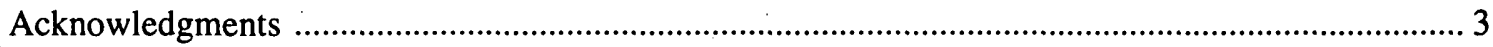

Site, well and subsurface data: Ground-Water Site Inventory .............................................................. 4

National Water-Quality Assessment Program pilot-study results........................................................ 4

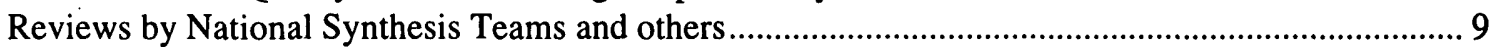

General guidance on site, well, and subsurface data collection,

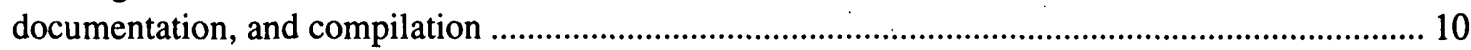

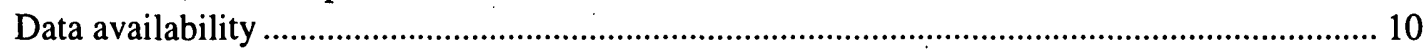

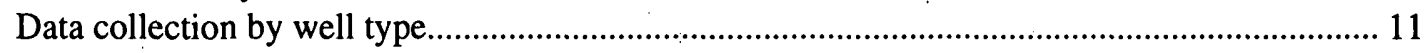

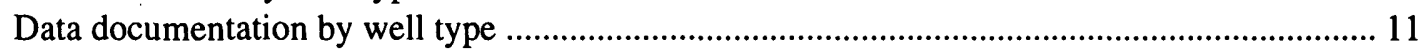

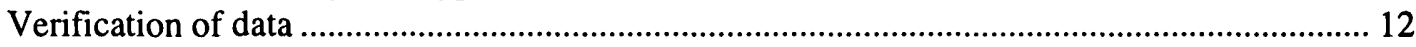

Specific guidance for selected site, well, and subsurface data...................................................... 12

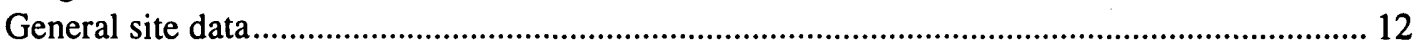

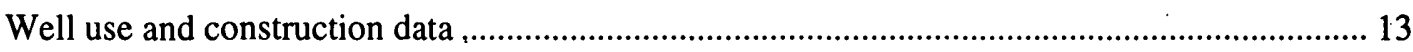

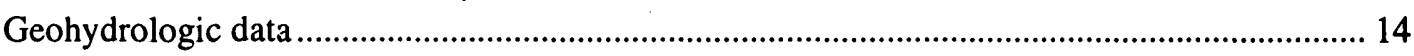

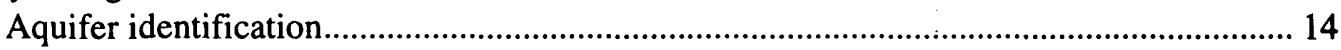

Primary contributing unit-definition and lithologic description ..................................... 15

Multiple contributing units ............................................................................................... 21

Land-use, management, and other data: Land-Use and Land-Cover Field Sheet .................................... 24

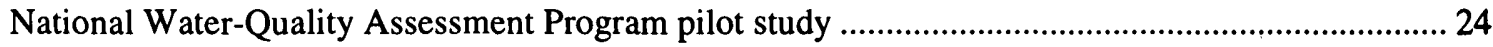

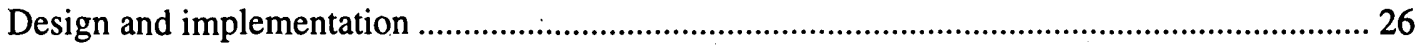

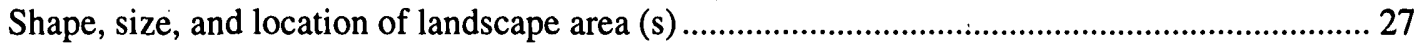

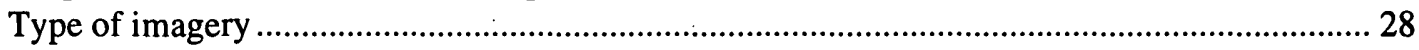

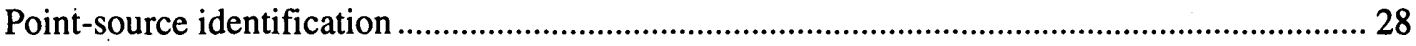

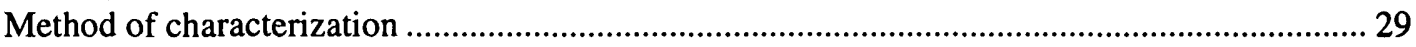

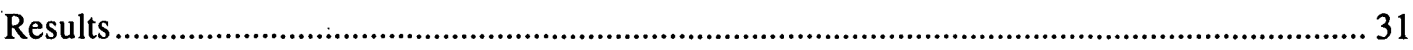

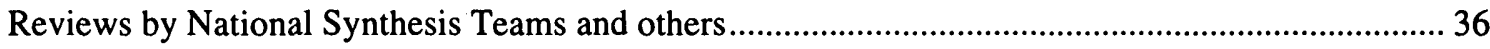

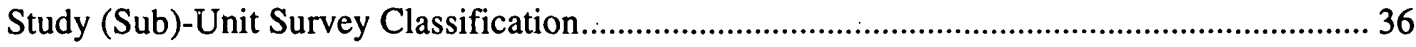

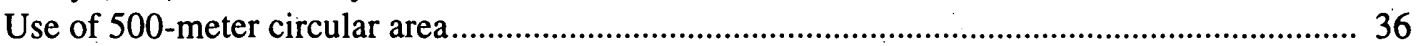

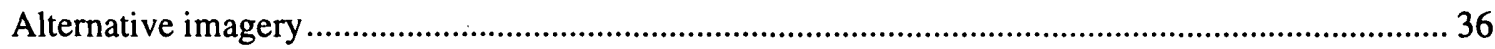

Recommendations of the National Synthesis Teams and other reviewers.......................................... 42

General guidance on landscape data collection, documentation, and compilation .............................. 42

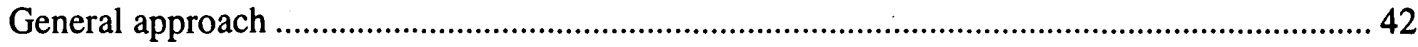

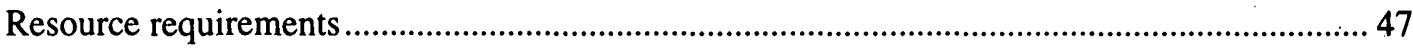

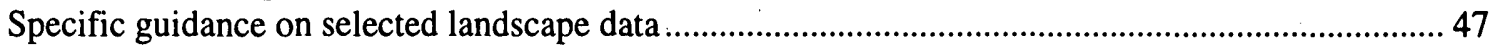

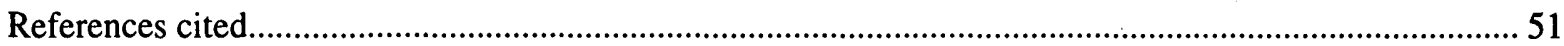




\section{CONTENTS--Continued}

Appendixes

A: NAWQA December 199.7 Land-Use Land-Cover Field Sheet

[Note: There are only 3 tables in this appendix. The table numbers correspond to the item numbers for consistency in the appendix.) For example, item 3, contains table 3; therefore, this is table A3.]

A3. Major land uses and practices identified in vicinity of the well. 56

A4. Occurrence of selected local features in the vicinity of the well.

A6. Evaluation of well in relation to the NAWQA design criteria for the ground-water components for which well is used.

B: NAWQA Land Use and Land-Cover Definitions and Codes

B1. Comparison of National Water-Quality Assessment Program and Anderson and Others (1976) Land-Use Categories.

B2. Minimal areal size requirement to identify a land use and cover within 500 meters of a well that requires. landscape characterization for a National Water-Quality Assessment Study (SUS)-Unit Survey or Land-Use Study.

B3. Land use and cover definitions and codes for Study (Sub)-Unit Survey (SUS) wells.

B4. General land use and cover definitions by categories and codes for Land-Use Study wells.

B5. Urban (chiefly residential and commerical) land use and cover definitions by categories and codes for Land-Use Study wells.

B6. Subcategories of land use and cover for agricultural lands with known livestock or crop.

B7. Subcategories for agricultural lands that are non-productive or whose productivity is unknown

B8. Categories and subcategories of land use and cover for visible mining landscape.

\section{FIGURES}

1. Definitions of the primary contributing unit for an observation well pumped at low-rate pump discharge (no major change in ground-water-flow pattern):

four examples with different hydrogeologic and well settings. 16

2. Field sheet for the characterization of landscape within 50 meters of a well 30

3. Example of a completed land use and cover characterization of landscape within 500 meters of a well in a predominantly urban (commercial-residential) setting 


\section{FIGURES--Continued}

4. Example of a completed land use and cover characterization of landscape within 500 meters of a well in a predominantly agricultural setting

5. Example of a completed land use and cover characterization of

landscape within 500 meters of a well in a reclaimed mining area

\section{TABLES}

1. Ground-Water Site Inventory data required for wells used to collect

water-quality data for the National Water-Quality Assessment Program.

2. Guidance on the collection and storage of horizontal

(latitude and longitude) location data for wells used

for the National Water-Quality Assessment Program

3. Accuracy of Precise Lightweight Global Receiver (PLGR) Units

4. Guidance to determine the vertical extent of the primary contributing unit

5. Selected lithologic descriptors for the primary contributing unit to a well

6. Example of lithologic data and coding of data for primary contributing unit of a well.

7. Selected geologic and lithologic features to incorporate in the description of the primary contributing unit of a well

8. Examples of U.S. Geological Survey studies that relate differences in land use and cover to ground-water quality

9. Time required to prepare, conduct, and complete pilot landscape characterization

10. Breakdown of total time required for selected activities to complete

landscape characterization

11. Recommendations and comments from

National Water-Quality Assessment Program Study-Unit teams

and Central Processing Group.

12. Reasons to characterize landscapes, and criteria to determine if characterization is necessary, for

Study (Sub)-Unit Survey (SUS) Wells

13. Comparison of Anderson 1970's land-use data corrected for

1990 population density (GIRAS) data to

National Aerial Photography, field-verified (1996-97)

land-use (NAP) data for area within 500 meters of well 


\section{TABLES--Continued}

14. Comparison of thematic imagery 1990's land-use data to

National Aerial Photography, field-verified (1996-97)

land-use data for area within 500 meters of the well

15. Work items, and parties responsible, for the completion

of the Land-Use and Land-Cover Field Sheet for a well

16. Recommended timing of activities for a ground-water

component of the National Water-Quality

Assessment (NAWQA) Program

17. Recommended sequence of activities after water-quality sampling

to obtain landscape data for wells used by the National Water-Quality

Assessment (NAWQA) Program.

CONVERSION FACTORS, ABBREVIATIONS, AND VERTICAL DATUM

\begin{tabular}{rcll}
\hline & Multiply & By & To obtain \\
& & Length & \\
& inch (in.) & 2.54 & centimeter \\
inch (in.) & 25.4 & millimeter \\
foot (ft) & 0.3048 & meter \\
mile (mi) & 1.609 & kilometer \\
& Area & \\
& acre & 0.4047 & hectare \\
& 0.09290 & square meter \\
& square foot (ft. ${ }^{2}$ ) & square kilometer \\
square mile (mi ${ }^{2}$ ) & 2.590 & \\
& Flow rate & liter per second \\
& 0.06309 & cubic meter per day \\
\hline
\end{tabular}

\section{LIST OF ACRONYMS}

$\begin{array}{llll}\text { CPG } & \text { Central Processing Group for LULCFS } & \text { NAP } & \text { National Areal Photography (from EROS) } \\ \text { EROS } & \text { Earth Resource (s) Observation Service } & \text { NAWQA } & \text { National Water-Quality Assessment (Program) } \\ \text { FPS } & \text { Flow-Path Study } & \text { NLT } & \text { National Leadership Team (NAWQA) } \\ \text { GWSI } & \text { Ground-Water Well (Site) Inventory Schedule } & \text { NST } & \text { National Synthesis Teàm (NAWQA) } \\ \text { LULCFS } & \text { Land-Use and Land-Cover Field Sheet } & \text { PLGR } & \text { Precise Lightweight Global Receiver } \\ \text { LUS } & \text { Land-Use Study } & \text { SUS } & \text { Study (Sub)-Unit Survey } \\ \text { NADASIG } & \text { NAWQA Data and Software Integration Group } & & \end{array}$




\title{
Ground-Water Data-Collection Protocols and Procedures \\ for the National Water-Quality Assessment Program: \\ Collection, Documentation, and Compilation of Required \\ Site, Well, Subsurface, and Landscape Data for Wells
}

\author{
By Michael T. Koterba
}

\begin{abstract}
Specified protocols and recommended procedures are used to guide the collection of data needed to achieve objectives of the National Water-Quality Assessment (NAWQA) Program of the U.S. Geological Survey (USGS). For ground water, these protocols and procedures include the installation or selection of wells, the collection of water-quality samples and data from each well, and the collection of ancillary data in the vicinity of each well. Collection of these data is considered essential to assess current and future water-quality conditions, and to evaluate any changes in water quality.

This report describes the ancillary data to be collected for wells used in the NAWQA Program, and the required or recommended methods to obtain these data. Data to be collected includes information on (1) well location, (2) well construction, (3) subsurface conditions and (4) landscape conditions. Methods of data collection incorporate field observations, use of high-resolution imagery, and historical record searches. The data collected and, if necessary, the methods used, are documented on standardized forms, and compiled electronically in either USGS or NAWQA national data bases.
\end{abstract}




\section{Introduction}

The National Water-Quality Assessment (NAWQA) Program of the U.S. Geological Survey (USGS) was fully implemented in 1991. To date, about 40 of the 60 planned Study Units, which range in area from 1,200 to more than $60,000 \mathrm{mi}^{2}$, have conducted ground-water studies in major aquifer systems in the Nation. More than 5,000 wells have been selected or installed throughout the Nation in areas within these Study Units, and as part of NAWQA Land-Use Studies (LUS) or Study (Sub)-Unit Surveys (SUS). By the year 2002, when all of the Study Units have participated, it is expected that the total number of LUS and SUS wells will exceed 7,500.

Protocols and recommended procedures to support the ground-water studies in the NAWQA Program include guidance on the installation or selection of wells (Lapham and others, 1995) and on the collection of water-quality samples and data from these wells (Koterba and others, 1995). These reports also describe the minimal ancillary data required to establish well and water-quality records in the USGS Ground-Water Site Inventory (GWSI) and Water Quality (QWDATA) electronic data bases.

When these reports were published in 1995, both indicated that the ancillary data requirements for NAWQA wells were under review, and that this review could revise and expand the scope of required ancillary data. This review and revision process formally begin in 1966, and examined site, well, subsurface, and landscape and management data, hereafter referred to as ancillary data, that could be used by NAWQA to meet national study objectives. These objectives include (1) the description of current ground-water-quality conditions, (2) the identification of possible changes or trends in water-quality conditions, and (3) the evaluation of water-quality conditions in relation to human activities and natural factors for the major part of the Nation's ground-water resources.
The ancillary data that were reviewed ranged in scope from those which simply, accurately, and easily allow one to locate wells, either geographically, or in relation to known local and national aquifers, to those which allow one to interpret the possible effects of either well, aquifer, landscape, or management characteristics on ground-water quality. Also considered were ancillary data requirements that provide the types of information that other water-resource programs or agencies often directly seek, or need to select, wells for their own studies.

The review also included a pilot study to assess the methods used to collect, document, and compile the ancillary data. ${ }^{1}$ The process also incorporated comments and considerations of pilot-study participants and other individuals from the NAWQA Program and the Water Resources Division of the USGS. This report is the result of the review, pilot study, and revison process.

\section{Purpose and Scope}

This report focuses on ancillary data required for wells from which water-quality data are collected for the USGS NAWQA Program. These ancillary data include selected features or conditions of the site, the well, the subsurface at the well; and the landscape, and land-management activities in the vicinity of the well. The purpose of this report is to (1) clearly identify what ancillary data are required in relation to each of these features or conditions, and (2) describe and promote the use of consistent and quantitative methods for the collection, documentation, and compilation of the ancillary data.

Lapham and others (1995) described information expected in well files (p. 41), and required to establish well and ground-water-quality records in USGS data bases (table 11; p. 44). This report expands the list of required well and subsurface data to include additional data on well, aquifer, and lithologic characteristics that can be used in the interpretation and evaluation of the water-quality data obtained from the wells.

\footnotetext{
1. T.L. Miller, U.S. Geological Survey, June, 1996. National WaterQuality Assessment Program Memorandum with Commentary and General Discussion of the Pilot Approach to Characterize Well Installation and Construction and Land Use and Cover for NAWQA Wells.
} 
This report also expands on the ancillary data previously required to describe the landscape and land-management practices in the vicinity of wells, and revises the methods used to obtain, document, and compile these data. In 1991, NAWQA StudyUnit teams described landscapes in accordance with a Land-Use and Cover-Field Sheet (LULCFS) originally developed in the Pilot NAWQA Program (Hardy and others, 1989). The LULCFS sheet was revised for this report (see Appendix A), as were the suggested methods to collect, document, and compile the landscape data for each well.

Overall, ancillary data requirements and methods were revised and expanded on the basis of a comprehensive review process. This process considered the protocols described by Lapham and others in 1995. It incorporated results of some NAWQA Study Units that utilized a quantitative approach to landscape descriptions and used the resulting landscape data to evaluate water-quality conditions. It also incorporates findings from other USGS studies in which ancillary data from wells were used to explain ground-water-quality conditions. Finally, it includes results from a NAWQA pilot study specifically designed to aid the revision process. In addition, throughout the entire review process, regular discussions were held with personnel within the USGS Water-Resources Division to identify important ancillary data and the methods to obtain, document, and compile those data. Personnel within NAWQA included individuals from at least seven Study-Unit teams, the National Leadership Team and its support group, the National Synthesis Teams, and the Central Processing Group (CPG) for LULCFS data.

Because of their significance, the required ancillary data on well, subsurface, land-use, and land-management features described in this report will become part of the NAWQA National Data Base Archive. For data initially stored in GWSI, this will be implemented through archival requests to individual Study-Unit teams from the NAWQA Data and Software Integration Group (NADASIG). The ancillary data obtained by initial completion of the LULCFS (Appendix A) will be stored in the NAWQA data base by the CPG, who will perform this operation as part of their processing of each LULCFS.
The revised ancillary data requirements and methods described in this report are for wells, and are not intended to be comprehensive for all types of ground-water data collection. For example, this report does not imply these are the ancillary data requirements for sampling water from springs. In addition, Study-Unit or National Synthesis Teams of the NAWQA program could require additional ancillary data to meet their specific objectives. Nevertheless, the required ancillary data and methods described in this report are considered vital to successful completion of the major NAWQA Program objectives.

For the purpose of presentation, the identification, description, and methods used to collect, document, and compile the required data are divided into two separate sections. The first section (Site, Well, and Subsurface Data: GroundWater Site Inventory) describes the required ancillary data on well and subsurface features. The second section (Land-Use, Management, and Other Data: Land-Use and Land-Cover Field Sheet) mainly describes required landscape data. It also includes a re-evaluation of each well in relation to NAWQA design and objective criteria that currently cannot be readily stored in GWSI, and, therefore, is part of the LULCFS. From a pragmatic viewpoint, Study-Unit teams should collect the required data for GWSI and the LULCFS in as efficient a manner as possible. This could involve the simultaneous collection of some subsurface and landscape data during the same visit to a well.

\section{Acknowledgments}

Deep appreciation and thanks are extended to the NAWQA Pilot-Study participants from the following Study Units: William Andrews and Paul Hanson of the Upper Mississippi River Basin; Gerard Gonthier of the Mississippi River Embayment; Barbara Dawson and Donna Knifong of the Sacramento River Basin; Paul Stackelberg and Richard Clawges of the Long Island-New Jersey Coastal Drainages; William Blanks and Eric Reuber of the Santee River Basin and Coastal Drainages; Jay Hawkins and Gregory Hawkins of the Allegheny-Monongahela Basin; and Timothy Cowdery of the Red River of the North Basin. Consistent and efficient methods to identify, 
collect, and document the ancillary data described in this report mainly are the result of the efforts of these individuals.

Most of the method development work leading up to and following the Pilot Study required the expertise of many individuals within and outside of the NAWQA Program. For this reason, the author is indebted to the each of the following groups of individuals:

John Brakebill and Scott Ator of the Potomac River Basin Study Unit, who provided early guidance and assistance on the development of field and processing methods to quantify land use and cover;

Bryan Schaap, Craig Harvey, and Dana Kolpin of the NAWQA CPG, USGS, Iowa District, who developed a centralized method to compile and process the LULCFS for all NAWQA Study Units;

Kerie Hitt and Gail Thelin, USGS, NAWQA Geographic Information System support team members; for their assistance, on relatively short notice, in the evaluation of possible alternative types of remote imagery to use in conjunction with the LULCFS;

Marilee Horn, USGS, New Hampshire District, Marti E. Ikehara, USGS, California District, and Kathleen M. Neitzert, USGS, South Dakota District; for their efforts and assistance in the development of procedures to identify, document, and compile subsurface information for NAWQA wells in the GWSI database; and

Jack Barbash, Curtis Price, Wayne Lapham, Paul Squillace, Bernard Nolan, Thomas Lopes, and Dennis Helsel; who as representatives of the NAWQA National Synthesis Teams provided comments, critiques, and suggestions throughout the review process.

Special thanks are extended to Wayne Lapham; NAWQA National Program, Reston, Virginia, and to Dana Kolpin, USGS, Iowa District. They not only contributed at many stages of the revision process, but also graciously provided excellent colleague reviews for this report. The author also wishes to thank Valerie Gaine, for her thoughtful editorial assistance, and Donna Knight for preparation of the manuscript, and G. Jean Hyatt and Timothy Auer for preparation of illustrations for this report.

\section{Site, Well, and Subsurface Data: Ground-Water Site Inventory}

The Ground-Water Site Inventory (GWSI) ancillary data requirements focus on site, well, and geohydrologic characteristics or conditions critical to identification of the well and its location, or those that could aid in the evaluation of water-quality data (table 1). These ancillary data were selected, and the methods used to obtain these data were developed, on the basis of two major activities. The first activity was a Pilot Study conducted by selected 1994 NAWQA Study-Unit teams (see Acknowledgments). The second activity was a review of this pilot effort, and of previous data requirements as described by Lapham and others (1995), by the participating NAWQA Study-Unit and National Synthesis Teams, their support groups, and others in the USGS Water Resources Division (see Acknowledgments).

\section{National Water-Quality Assessment Program Pilot-Study Results}

T.L. Miller described the need and outlined the basic requirements of a pilot study that included the collection of selected well and subsurface data. ${ }^{2}$ Six 1994 Study-Unit teams collected the required data (table 1, except for items marked "A"), and compiled them in GWSI. In addition, the pilot teams recorded information on the resources required (study-unit personnel hours and direct costs for personnel hours or other expenditures) to complete this activity.

\footnotetext{
2. T.L. Miller, U.S. Geological Survey, June, 1996. National WaterQuality Assessment Program Memorandum with Commentary and General Discussion of the Pilot Approach to Characterize Well Installation and Construction and Land Use and Cover for NAWQA Wells.
} 
Table 1. Ground-Water Site Inventory data required for wells used to collect water-quality data for the National Water-Quality Assessment Program ${ }^{a}$

[M, mandatory to create selected data-base records; A, added by pilot-study review; PLGR, Precise Lightweight Global Receiver; NAD83, Navigational Reference Datum of 1983; \#, \#\#,... numeric values; FIPS, Federal Information Processing Standards; GIS, Geographic Information System]

\begin{tabular}{|c|c|c|c|c|}
\hline \multicolumn{3}{|c|}{ DATA } & \multicolumn{2}{|l|}{ GUIDANCE } \\
\hline Type & Parameter & $\begin{array}{l}\text { GWSI } \\
\text { code }\end{array}$ & $\begin{array}{l}\text { Definition and format to use for Ground-Water Site } \\
\text { Inventory (GWSI) data base }\end{array}$ & $\begin{array}{l}\text { Best time to obtain } \\
\text { and means to } \\
\text { record data }\end{array}$ \\
\hline \multirow[t]{14}{*}{ GENERAL } & $\begin{array}{l}\text { Site (well) } \\
\text { identifier }\end{array}$ & $\mathrm{C} 001, \mathrm{M}$ & $\begin{array}{l}\text { USGS+15-digits (where digits are latitude, longitude, and } \\
\text { sequence number; example: } 394224075340501 \text { ); round data } \\
\text { to nearest second to create identifier. }\end{array}$ & \multirow{8}{*}{$\begin{array}{l}\text { As soon as well is } \\
\text { actually selected or } \\
\text { installed. Directly } \\
\text { on the GWSI form, } \\
\text { and noting in } \\
\text { margins source of } \\
\text { data for a selected } \\
\text { well. A site } \\
\text { identifier that already } \\
\text { is in GWSI for a } \\
\text { selected well should } \\
\text { not be changed. }\end{array}$} \\
\hline & Site type & $\mathrm{C} 002, \mathrm{M}$ & Use "W", for "well". & \\
\hline & Data reliability & C003. M & $\begin{array}{l}\text { Use "C", which, for NAWQA, implies data was at least } \\
\text { checked if not obtained directly by NAWQA staff. }\end{array}$ & \\
\hline & Reporting agency & $\mathrm{COO4}, \mathrm{M}$ & Use "USGS" for the United States Geological Survey. & \\
\hline & Project code & $\mathrm{C} 005, \mathrm{~A}$ & Use code for National Water-Quality Assessment Program & \\
\hline & District user & $\mathrm{C} 006, \mathrm{M}$ & $\begin{array}{l}\text { A two-digit number (\#\#) for the USGS District/User } \\
\text { (example: } 24, \text { Maryland). }\end{array}$ & \\
\hline & State & $\mathrm{C} 007, \mathrm{M}$ & $\begin{array}{l}\text { A two-digit number (\#) for the State (example: } 10 \text {, } \\
\text { Delaware); from FIPS codes. }\end{array}$ & \\
\hline & County & $\mathrm{C} 008, \mathrm{M}$ & $\begin{array}{l}\text { A three-digit number (\#\#) for county, township, or section } \\
\text { (example: 003, Sussex County); from FIPS codes. }\end{array}$ & \\
\hline & $\begin{array}{l}\text { Hydrologic Unit } \\
\text { Code }\end{array}$ & $\mathrm{C} 020, \mathrm{~A}$ & $\begin{array}{l}\text { A eight-digit number (\#) code for the Hydrologic } \\
\text { Unit in which well is located (example: } 02060006 \text {, } \\
\text { Patuxent River Basin, Md.); from Hydrologic Unit maps for } \\
\text { States; need similar horizontal reference datums. }\end{array}$ & $\begin{array}{l}\text { When GIS coverage } \\
\text { is available. }\end{array}$ \\
\hline & $\begin{array}{l}\text { Latitude, as } \\
\text { measured (to tenth } \\
\text { of a second) }\end{array}$ & $\mathrm{C} 009^{b}, M$ & $\begin{array}{l}\text { To be revised; in anticipation of revision, use 8-place (single } \\
\text { decimal) number (\#\#\#\#\#.\#) for degrees, minutes, seconds, } \\
\text { and tenths of seconds, respectively (example: } 394224.1 \text { ); } \\
\text { SEE TEXT. }\end{array}$ & \multirow{5}{*}{$\begin{array}{l}\text { Measured with } \\
\text { PLGR, preferably at } \\
\text { first visit to an } \\
\text { already selected well } \\
\text { or at time well is } \\
\text { installed. Directly } \\
\text { on GWSI form } \\
\text { (modified for as } \\
\text { measured data, or in } \\
\text { margins of } \\
\text { unmodified form). }\end{array}$} \\
\hline & $\begin{array}{l}\text { Longitude, as } \\
\text { measured (to tenth } \\
\text { of a second) }\end{array}$ & $\mathrm{C} 010^{\mathrm{b}}, \mathrm{M}$ & $\begin{array}{l}\text { To be revised; in anticipation of revision, use 9-place (single } \\
\text { decimal) number for (\#\#\#\#) for degrees, minutes, } \\
\text { seconds, and tenths of seconds, respectively (example: } \\
075340501.2 \text { ); SEE TEXT, }\end{array}$ & \\
\hline & $\begin{array}{l}\text { Latitude-longitude } \\
\text { accuracy, as } \\
\text { measured }\end{array}$ & $\mathrm{C} 011^{\circ}, \mathrm{A}$ & $\begin{array}{l}\text { To be revised or new parameter added; in anticipation of } \\
\text { revision, up to 3-digit number (\#\#\#), for PLGR to nearest } \\
\text { meter; from readout given by PLGR unit at time and } \\
\text { location that latitude and longitude are determined; SEE } \\
\text { TEXT. }\end{array}$ & \\
\hline & $\begin{array}{l}\text { Latitude-longitude, } \\
\text { method of } \\
\text { measurement }\end{array}$ & $\mathrm{C} 035^{\mathrm{b}}, \mathrm{A}$ & $\begin{array}{l}\text { To be added; in anticipation of revision, use "GPS, PLGR" } \\
\text { (or second order survey) with NAD83 as basis for latitude } \\
\text { and longitude as measured. }\end{array}$ & \\
\hline & $\begin{array}{l}\text { Latitude-longitude, } \\
\text { reference datum }\end{array}$ & $\mathrm{C} 036^{\mathrm{b}}, \mathrm{A}$ & $\begin{array}{l}\text { To be added; in anticipation of addition, use "NAD83" as } \\
\text { basis for latitude and longitude as measured; SEE TEXT. }\end{array}$ & \\
\hline
\end{tabular}


Table 1. Ground-Water Site Inventory data required for wells used to collect water-quality data for the National Water-Quality Assessment Program ${ }^{{ }^{-}-\text {-Continued }}$

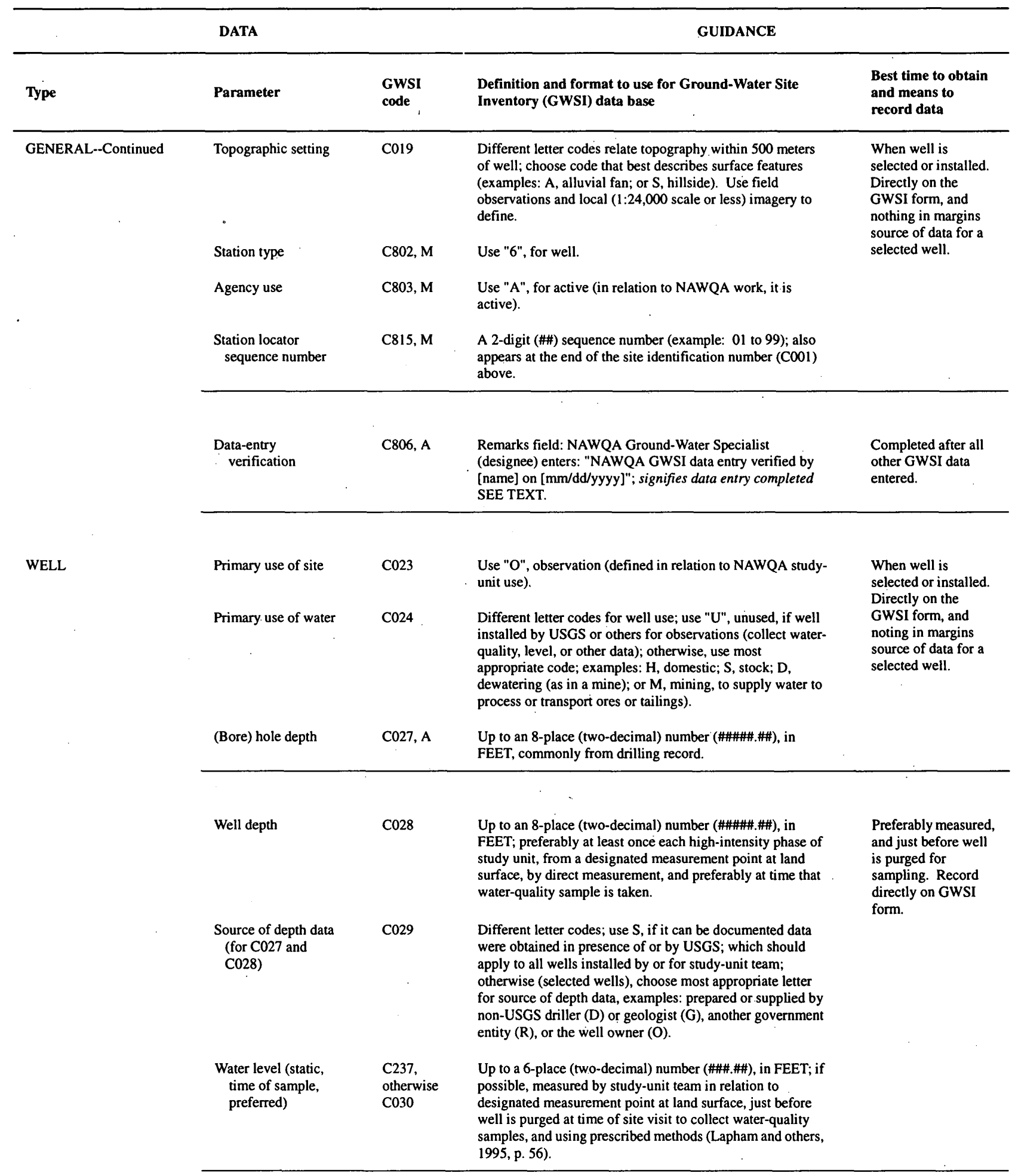


Table 1. Ground-Water Site Inventory data required for wells used to collect water-quality data for the National Water-Quality Assessment Program ${ }^{a}$--Continued

\begin{tabular}{|c|c|c|c|c|}
\hline \multicolumn{3}{|c|}{ DATA } & \multicolumn{2}{|l|}{ GUIDANCE } \\
\hline Type & Parameter & $\begin{array}{l}\text { GWSI } \\
\text { code }\end{array}$ & $\begin{array}{l}\text { Definition and format to use for Ground-Water Site } \\
\text { Inventory (GWSI) data base }\end{array}$ & $\begin{array}{l}\text { Best time to obtain } \\
\text { and means to } \\
\text { record data }\end{array}$ \\
\hline \multirow[t]{14}{*}{$\begin{array}{l}\text { WELL.- } \\
\text { Continued }\end{array}$} & Type of lift & $\mathrm{C} 043$ & $\begin{array}{l}\text { Under Construction-Lift Data (R42) requires designation of } \\
\text { Record Type (752): LIFT, Record Sequence Number } \\
\text { (254):001, and Type of Lift (43): Different letter codes; for } \\
\text { observation well and use of submergible portable pump (for } \\
\text { example, Fultz, Keck, Grundfos RF-II) use S; for } \\
\text { production well, use most appropriate code. }\end{array}$ & $\begin{array}{l}\text { When well is } \\
\text { selected or installed. } \\
\text { Directly on the } \\
\text { GWSI form, and } \\
\text { noting in margins } \\
\text { source of data for a } \\
\text { selected well. }\end{array}$ \\
\hline & $\begin{array}{l}\text { Date of } \\
\text { construction }\end{array}$ & $\mathrm{C} 060$ & $\begin{array}{l}\text { Under Well-Construction Data (R58) requires designation } \\
\text { of Record Type (754): CONS, Record Sequence Number } \\
\text { (723):001, and Date of Construction (60): MM-DD-YYYY. }\end{array}$ & \\
\hline & $\begin{array}{l}\text { Method of } \\
\text { construction }\end{array}$ & $\mathrm{C} 065$ & $\begin{array}{l}\text { Part of CONS record; different letter codes; use most } \\
\text { appropriate. }\end{array}$ & $\cdot$ \\
\hline & Type of finish & $\mathrm{C} 066$ & $\begin{array}{l}\text { Part of CONS record; different letter codes; use most } \\
\text { appropriate. }\end{array}$ & \\
\hline & $\begin{array}{l}\text { Type of seal } \\
\text { (annular) }\end{array}$ & $\mathrm{C} 067$ & $\begin{array}{l}\text { Part of CONS record; different letter codes; use most } \\
\text { appropriate. }\end{array}$ & \\
\hline & $\begin{array}{l}\text { Depth to top of } \\
\text { casing (if used) }\end{array}$ & $\mathrm{C} 077^{\mathrm{c}}, \mathrm{A}$ & $\begin{array}{l}\text { Under Casing Data (R76) requires Record Type ( } 758) \text { : } \\
\text { CSNG, Record Sequence Number:001, Sequence Number } \\
\text { of Parent Record (59):001, and Depth to top of casing ( } 77 \text { ): } \\
\text { up to a 8-place (two-decimal) number (\#\#\#\#.\#), in FEET; } \\
\text { from land surface. }\end{array}$ & \\
\hline & $\begin{array}{l}\text { Depth to bottom of } \\
\text { casing (if used) }\end{array}$ & $\mathrm{C} 078^{\mathrm{c}}, \mathrm{A}$ & $\begin{array}{l}\text { Part of CSNG data; up to an 8-place (two-decimal) number } \\
\text { (\#\#\#\#\#\#), in FEET; from land surface. }\end{array}$ & \\
\hline & $\begin{array}{l}\text { Diameter of casing } \\
\text { (if used) }\end{array}$ & $\mathrm{C} 079^{\mathrm{C}}, \mathrm{A}$ & $\begin{array}{l}\text { Part of CSNG data; up to a 5-place (two-decimal) number } \\
\text { (\#\#.\#\#), in INCHES. }\end{array}$ & \\
\hline & $\begin{array}{l}\text { Casing material } \\
\text { (if used) }\end{array}$ & $\mathrm{C} 080^{c}$ & $\begin{array}{l}\text { Part of CSNG data; different letter codes (casing materials); } \\
\text { use most appropriate. }\end{array}$ & \\
\hline & $\begin{array}{l}\text { Depth to top of } \\
\text { open (screened) } \\
\text { interval. }\end{array}$ & $\mathrm{C} 083^{\mathrm{d}}$ & $\begin{array}{l}\text { Part of OPEN data; up to an 8-place (two-decimal) number } \\
\text { (\#\#\#\#), in FEET; in reference to either open part of } \\
\text { borehole, perforated casing, or screened interval. }\end{array}$ & \\
\hline & $\begin{array}{l}\text { Depth to bottom of } \\
\text { open (screened) } \\
\text { interval }\end{array}$ & $\mathrm{CO}^{2} 4^{\mathrm{d}}$ & $\begin{array}{l}\text { Part of OPEN data; up to an 8-place (two-decimal) number } \\
\text { (\#\#\#\#.\#\#), in FEET; in reference to bottom of either open } \\
\text { part of borehole, perforated casing, or screened interval. }\end{array}$ & \\
\hline & Type of interval & $\mathrm{C} 085^{\mathrm{d}}, \mathrm{A}$ & $\begin{array}{l}\text { Part of OPEN data; different letter codes (types of } \\
\text { intervals); use most appropriate. }\end{array}$ & \\
\hline & Interval material & $\mathrm{C} 086^{\mathrm{d}}, \mathrm{A}$ & $\begin{array}{l}\text { Part of OPEN data; different letter codes (types of material); } \\
\text { use most appropriate }\end{array}$ & \\
\hline & Diameter of interval & $\mathrm{C} 087^{\mathrm{d}}, \mathrm{A}$ & $\begin{array}{l}\text { Part of OPEN data; Up to a } 5 \text { place (two-decimal) number } \\
\text { (\#\#.\#\#), in INCHES. }\end{array}$ & \\
\hline
\end{tabular}

GEOHYDROLOGIC

$\begin{array}{ll}\begin{array}{l}\text { Primary (local) } \\ \text { aquifer } \\ \text { (code) name }\end{array} & \text { C714 (also } \\ & \text { C093) }\end{array}$

Required in two locations: (1) Primary Aquifer (C714), as part of GENERAL STTE Data (RO); and (2) Aquifer Identifier (C093), as part of GEOHYDROLOGIC Data (R90); up to 8-character codename, approved in GWSI, for local (District) name of aquifer that contains the open (screened) interval of the well; SEE TEXT.
After well has been selected or installed and aquifers identified. Directly on GWSI form. 
Table 1. Ground-Water Site Inventory data required for wells used to collect water-quality data for the National Water-Quality Assessment Program ${ }^{{ }_{--} \text {Continued }}$

\begin{tabular}{|c|c|c|c|c|}
\hline \multicolumn{3}{|c|}{ DATA } & \multicolumn{2}{|l|}{ GUIDANCE } \\
\hline Type & Parameter & $\begin{array}{l}\text { GWSI } \\
\text { code }\end{array}$ & $\begin{array}{l}\text { Definition and format to use for Ground-Water Site } \\
\text { Inventory (GWSI) data base }\end{array}$ & $\begin{array}{l}\text { Best time to obtain } \\
\text { and means to } \\
\text { record data }\end{array}$ \\
\hline \multirow[t]{6}{*}{$\begin{array}{l}\text { GEOHYDROLOGIC-- } \\
\text { Continued }\end{array}$} & $\begin{array}{l}\text { Principal aquifer } \\
\text { name }\end{array}$ & $\begin{array}{l}\text { C714 (also } \\
\text { C093) }{ }^{\mathrm{e}}, \mathrm{A}\end{array}$ & $\begin{array}{l}\text { Part of GENERAL SITE Data; a 1-letter code; use either } \\
\text { "C", confined single aquifer, or "U", unconfined single } \\
\text { aquifer; for broad condition of aquifer, not well; SEE TEXT. } \\
\text { Principal aquifer that contains local aquifer (C714 and } \\
\text { C093); identified from USGS Office of Ground Water } \\
\text { Principal Aquifer Database; created in accordance with a } \\
\text { specified procedure and format; SEE TEXT. }\end{array}$ & $\begin{array}{l}\text { After well has been } \\
\text { selected or installed } \\
\text { and aquifer } \\
\text { identified. Directly } \\
\text { on GWSI form. } \\
\text { Principal aquifer } \\
\text { name is from } \\
\text { national listing } \\
\text { derived for Study } \\
\text { Unit. SEE TEXT. }\end{array}$ \\
\hline & $\begin{array}{l}\text { (Primary) } \\
\text { contributing unit } \\
\text { designated }\end{array}$ & $\mathrm{C} 304^{\mathrm{e}}, \mathrm{A}$ & $\begin{array}{l}\text { Under GEOHYDROLOGIC Data (R90); requires Record } \\
\text { Type ( } 748) \text { : GEOH, Record Sequence Number ( } 721): 001 \text {, } \\
\text { Parent Sequence Number ( } 256): 001 \text {, and Contributing Unit } \\
\text { (304): use "P" for primary; SEE TEXT. }\end{array}$ & \multirow{5}{*}{$\begin{array}{l}\text { Initial lithologic data } \\
\text { from driller or other } \\
\text { log obtained for well } \\
\text { at time of selection } \\
\text { or installation. } \\
\text { Relevant vertical } \\
\text { dimensions of } \\
\text { primary contributing } \\
\text { unit, and description } \\
\text { of lithology in that } \\
\text { unit are determined } \\
\text { after well has been } \\
\text { sampled and it has } \\
\text { been determined if } \\
\text { the vertical } \\
\text { dimension of unit } \\
\text { should extend to land } \\
\text { surface. SEE TEXT } \\
\text { for further } \\
\text { discussion. }\end{array}$} \\
\hline & $\begin{array}{l}\text { Depth to top of } \\
\text { (primary) unit }\end{array}$ & $\mathrm{C} 091^{e}, A$ & $\begin{array}{l}\text { Part of GEOH record sequence; up to an 8-place (two- } \\
\text { decimal) number (\#\#\#.\#\#), in FEET; SEE TEXT. }\end{array}$ & \\
\hline & $\begin{array}{l}\text { Depth to bottom of } \\
\text { (primary) unit }\end{array}$ & $\mathrm{CO}^{2} 2^{\mathrm{e}}, \mathrm{A}$ & $\begin{array}{l}\text { Part of GEOH record sequence; up to an 8-place (two- } \\
\text { decimal) number (\#\#\#\#.\#\#), in FEET; SEE TEXT. }\end{array}$ & \\
\hline & $\begin{array}{l}\text { Lithology of } \\
\text { (primary) unit }\end{array}$ & $\cos ^{\mathrm{e}}, \mathrm{A}$ & $\begin{array}{l}\text { Part of GEOH record sequence; different 4-letter GWSI- } \\
\text { approved codes, use most appropriate to describe major } \\
\text { lithology in primary contributing unit (generally immediate } \\
\text { vicinity of open or screened interval); SEE TEXT. }\end{array}$ & \\
\hline & $\begin{array}{l}\text { Lithologic modifier/ } \\
\text { descriptor of } \\
\text { (primary) unit }\end{array}$ & $\mathrm{C} 097^{\mathrm{e}}, \mathrm{A}$ & $\begin{array}{l}\text { Part of GEOH record sequence; up to an 123-character } \\
\text { expanded lithologic description; identify by code, and in } \\
\text { order of occurrence from the top to the bottom of the } \\
\text { primary contributing interval, those lithologic units that } \\
\text { occur in this interval. For each lithologic unit: identify the } \\
\text { unit (in code), its thickness (in feet), and the potential } \\
\text { occurrence (natural sources) of any selected trace elements } \\
\text { and other chemical species that this unit could contribute to } \\
\text { ground water; SEE TEXT. }\end{array}$ & \\
\hline
\end{tabular}

a. Except as noted in guidance column above or in accompanying text, instructions for GWSI data-base entry can be obtained from the District GWSI Data Base Manager or possibly directly from district-linked access to GWSI (for example,currently (June, 1998), for eastern region, electronic access is through http:// www.nwis.er.usgs.gov/conversion/nwisdocs 2 _l/gw/GW.user.book. $h t m l$ ). Direct electronic access provides the most up-to-date GWSI guidance and support files. SEE TEXT which contains critical guidance for selected GWSI parameters to provide consistency in codes, and to avoid errors in the GWSI data base. Recommend that data entry, retrieval, and review procedures be discussed with District GWSI data manager.

b. Current (as of May, 1998) USGS Water Resources Division policy for GWSI data entry (1) requires latitude and longitude be reported in relation to seconds and the 1927 national reference datum; but (2) planned (Post-May, 1998, GWSI release 3_1) update to GWSI will allow storage of data to nearest tenth of second and in relation to the modern 1983 national reference datum. Update also will allow storage of method accuracy (in meters, and to tenth of second), method used (such as PLGR), and reference datum (such as NAD83). Accompanying text in this report discusses how to document, manage, and store data in GWSI.

c. $\mathrm{C} 077$ through $\mathrm{C} 080$, ideally, in accordance with NAWQA guidance on well selection or installation, there is only one open (screened) interval to well.

d. $\mathrm{C} 714$ through $\mathrm{C} 097$ must be specified for the aquifer and the primary contributing unit in this aquifer.

e. The principal aquifer is identified in GWSI data base initially through the use of a Remarks code, which is then assigned a parameter code, at the time of remarks code entry. SEE TEXT for further discussion. 
Pilot-study results indicate that Study-Unit teams collected most of the required well and subsurface data for either installed (mainly LUS) wells or selected (mainly SUS) wells. For an LUS (of generally 30 wells), the total time required per Study-Unit team to complete all work ranged from 8 hours to 60 hours, but typically was about 40 hours. Differences in the time required were mainly the result of differences in the times spent on fielddata collection, or data documentation and checking, and the number and level of staff involved. Given the few equipment needs, total personnel time also was the major cost associated with this effort, which in FY97 funds, ranged from just over $\$ 100$ to almost $\$ 1,000$ per team.

Resource requirements were lowest for pilot teams that (1) initially collected GWSI data directly on the well and GWSI forms rather than in field notebooks, and then transposed the data to these forms; (2) used a single, trained field technician (permanent or temporary) to collect all data after some initial supervision at the time any well was installed; (3) used a skilled data-management person to perform electronic searches for any required data, for example, to either select wells or select sites for well installation; and (4) used an employee well-versed in GWSI for data input, editing, and verification. Study-Unit teams that follow this approach should be able to complete GWSI work for an LUS (of 30 wells) in about 30 hours.

Pilot costs did not account for a suitable global positioning system (GPS) to determine well location (latitude and longitude). A suitable, highly recommended, Precise Lightweight Global Receiver (PLGR) or GPS unit for NAWQA Study Units is available from the USGS GPS-PPS Coordinator, Water Resources Division.

No Pilot-Study estimates of resource requirements and costs are available for Study (Sub)-Unit Survey (SUS) wells. The two Study-Unit teams that did SUS ground-water components completed their GWSI requirements before resource estimates were requested. If the SUS wells ultimately selected have the required data readily available (electronically and on paper files), or obtainable from the field during site visits, however, then SUS resource requirements are similar to, or possibly less than, those for an LUS. Resource requirements will increase, however, if the required GWSI data only are obtainable from paper files located in different public and private locations, or require intensive data-collection at SUS well sites.

\section{Reviews by National Synthesis Teams and Others}

Pilot-study results were reviewed by individuals from the NAWQA National Synthesis Teams and two, NAWQA-related, national or regional initiatives (associated with the USGS Committee on Environmental and Natural Resources Monitoring and Assessment, and the USGS MidAtlantic Integrated Assessment Program). Their reviews identified additional GWSI data (table 1, "A" items) deemed critical to (1) the installation or selection of wells, (2) the identification of wells, or (3) the analysis and interpretation of water-quality data from these wells, either by NAWQA, or by others outside the NAWQA Program.

The NAWQA Central Processing Group, which processed the pilot LULCFS, and several other NAWQA support team members, who also require some GWSI-related data in their work, also reviewed the pilot results. Their reviews identified problems with the quality of some pilot GWSI data. For example, discrepancies did occur in horizontal location data (latitude and longitude) of wells. ${ }^{3}$ Namely, values specified on the pilot LULCFS (which also presumably are in GWSI) differed, in some cases markedly, from the data obtained by the NAWQA CPG during registration of the highresolution imagery that is used to characterize the landscape in the vicinity of a well.

Differences in the accuracy of well-location data possibly resulted from four problems. These include (1) interpolation of location data from USGS Quadrangle maps $(1: 24,000)$ that possibly lacked sufficient detail to accurately locate the well on the map, (2) use of different reference datum

3. Analyses related to this problem are presented and discussed in LandUse, Management, and Other Data: Land-Use And Land Cover Field Sheet section of this report (under Alternative Imagery subsection). 
(NAD27 or NAD83), (3) use of relatively inaccurate hand-held commercial GPS units, and (4) limitations in the accuracy with which location data are stored in the electronic data base (GWSI; only to the nearest second).

All reviews also found examples that illustrated several different ways that some types of ancillary GWSI data can be obtained or encoded in GWSI, which can lead to noticeable differences in the extent and accuracy of data collected. To reduce or eliminate these problems, reviewers strongly recommended that (1) the data required be clearly defined, (2) that guidance include consistent methods of data collection, documentation, and compilation, and (3) that modifications to this guidance be discussed by the Study-Unit team with their NAWQA Area Regional Specialist, the NAWQA Quality-Assurance (QA) Chief, and, as appropriate, individuals from support groups such as NADASIG and the CPG.

The reviews of the pilot process introduced some necessary changes in the type of ancillary data to collect, as well as, the methods by which some data are collected (table 1, "A" items). For example, it was strongly recommended the location (latitude and longitude) of the well be determined as follows: (1) using an accurate GPS, (2) in relation to the 1983 (horizontal) Navigational Reference Datum (NAD83), and (3) be accompanied by an estimate of the accuracy of that location whether wells are selected or installed. It also was strongly recommended that the required ancillary data be expanded to include the following: (1) specification of a regional or national aquifer name, as well as the local aquifer name, (2) a summary of the relevant lithologic data for each well, and (3) some indication to indicate that the GWSI work was reviewed and complete, particularly if not all the required data had been compiled.

Because of changes that resulted from the reviews of the pilot study, resource estimates provided earlier do not reflect the collection of all required GWSI data. Except for the required geohydrologic data (table 1 , geohydrologic), the added resources required to obtain the additional GWSI data, however, are marginal. For example, if NAWQA guidelines on LUS design are met (for example, see Appendix A: LULCFS, Section 6.E), most wells are installed. Most of the data needed to complete the geohydrologic data requirements are readily obtained during well installation (drilling, construction, or development).

Meeting the geohydrologic data requirements (table 1, geohydrologic data) could require an additional 8 to 10 hours per LUS. This would imply 30 to 40 hours of personnel time most likely will be required to obtain and complete all GWSI requirements for an LUS or SUS (of approximately 30 wells). This assumes that Study-Unit teams follow the guidance described for GWSI ancillary data collection, documentation, and compilation described in the sections that follow.

\section{General Guidance on Site, Well, and Subsurface Data Collection, Documentation, and Compilation}

The Study-Unit chief and ground-water specialist (or designee) share supervisory responsibility to ensure that the required GWSI data are obtained to the extent possible for each well at which NAWQA water-quality data are collected. To ensure all data are obtained to the extent possible the collection, documentation, and compilation of these data requires careful planning. During implementation of each of these activities, it also is best if initial efforts by Study-Unit staff are reviewed by the ground-water specialist to ensure that the activity obtains the desired result in an efficient and consistent manner. This is critical if more than one staff member performs that activity. Finally, once GWSI data compilation is complete to the extent possible, the data must be checked, and notification made in the GWSI data base to this effect, preferably by the Study-Unit ground-water specialist.

To plan, implement, and complete all GWSI activities, it is recommended that the Study-Unit chief and ground-water specialist generally be familiar with the data required (table 1). In addition, they must be aware of several factors that will affect data availability, documentation, and verification.

\section{Data Availability}

Ideally, the required GWSI data will be obtained for all wells. Differences in data availability can arise, however, if data collection is not well planned for installed wells, or is not adequately considered in the selection of wells. To collect, document, and compile the required GWSI data, and to do so in an efficient manner, plans for GWSI data collection 
need to account for what data are required, and when, how, and where to obtain and record that data (table 1). In addition, one needs to be aware of how these data are to appear in GWSI. For example, when, how, and where GWSI data are best obtained generally differs depending on well type--whether new wells are being installed or existing wells are being selected. Differences in well type also will commonly affect the manner and timing of data collection, and the procedures used to document and compile the required GWSI data.

Understanding these effects will lead to better planning for the collection of the required GWSI data.

\section{Data Collection by Well Type}

The ground-water component of the NAWQA Program employs two types of wells. The first type consists mainly of observation wells installed by or for the Study-Unit team (for example, mainly LandUse or Flowpath Study wells). The second type are existing wells that are selected for use in the study (for example, mainly Study (Sub)-Unit Survey wells). These selected wells commonly are either private or public, and generally were installed by organizations other than the USGS for the purpose of domestic or public water supply, commercial or industrial supply, or irrigation.

For installed wells, most of the required GWSI data (table 1) are best obtained (recorded) at the time of well installation, by a single individual who is assigned that task. To ensure these data can be collected, this individual's efforts are explicitly identified as part of the well-drilling contract. To enhance the consistency and efficiency of data collection, data should be recorded directly on the well and GWSI forms.

For selected wells, most of the required data are best obtained at the time wells are selected, and where well selection takes into account the availability of the required data. This generally requires that the person responsible for well selection be adept at record searches of either paper or electronic files.

Except for some geohydrologic data (table 1, geohydrologic), the NAWQA process and criteria for well selection (see for example, Appendix A; item 6 , table 6), combined with the data required to establish GWSI and QWDATA records (table 1, items with "M"), imply that many of the required
GWSI data should exist for a well that has been selected. Therefore, if these data do not exist for any well in the vicinity of the sampling site chosen by the NAWQA design process, an alternate site should be considered. Alternately, if several wells at a site all meet other NAWQA selection criteria, but none provide all required GWSI data, the well selected should be from among those for which the missing GWSI data are obtainable.

For consistency and efficiency, the task of well selection and records searches for available GWSI data for wells should be assigned to one individual. If more than one individual is involved, each must operate under the same rules noted above for site and well selection.

Whether the well is installed or selected, planning efforts to obtain the required data need to consider that some GWSI data are best collected each time a visit is made to the well (table 1 , for example, well depth), while other data are best collected at the time water-quality samples are taken, and by those collecting water-quality samples (table 1, for example, water-level elevation). Finally some of the GWSI data require information be obtained on several different occasions. (For example, the identification and description the primary contributing unit (table 1, under geohydrologic data) are best completed after data have been obtained on lithologic materials (at time well is installed or selected) and on groundwater quality (after samples have been collected and analyzed.)

\section{Data Documentation by Well Type}

Documentation procedures for the required data differ depending on whether the well is installed or selected. For installed wells, they include the completion, preferably on site, of forms such as that described by Lapham and others (1995, figs. 8, 9 , and 10; p. 45-51), or using revised forms (Lapham and others, 1996, fig. 2, p. 14-15, and figs. 15, 16, and 17, p. 89-96). Regardless of which forms are used, they should cover at least the required GWSI data.

For selected wells, the required GWSI well and site data are documented on the same type of well forms as those described above for installed wells. For selected wells, however, it should be clearly indicated, in margins if need be, what the original source (s) of information were for completed parts 
of the well forms. Possible sources include electronic or paper records from the USGS or others, or from data collected by the Study-Unit team from a field trip to the well. When an original source document is available for copying, a (photo) copy of this document should be obtained and filed. As in the case of installed wells, information that reasonably can be obtained and recorded on well forms, or as photocopies of original sources, should provide information that is at least as detailed as that which appears on the GWSI form. In turn, the latter must be completed (or an existing GWSI form revised), by the Study-Unit team to document data that are added (or corrected) in the GWSI database.

Upon completion, the well and GWSI forms, along with any drilling or other logs or sedimentcore analyses, or copies of these, are stored with site maps, sketches, and photographs in the Study-Unit well file (Lapham and others, 1995). Furthermore, except for geohydrologic data collected when the well is installed or selected, and water-level data collected at the time of sample collection, all other required data should be entered into GWSI before water-quality samples are obtained from the well. Because some of the geohydrologic data to be entered in GWSI (table 1, geohydrologic, primary contributing unit, lithologic descriptors) depend on assessment of the water-quality data obtained from the well, these data are not entered into the GWSI record until after water-quality samples have been collected, and the analytical data from the samples are obtained. But once this is done, and the waterlevel data obtained at the time of water-quality sampling are entered, GWSI data-entry should be complete. This is when the GWSI data should be verified.

\section{Verification of Data}

The required GWSI data should be reviewed for completeness and data-entry errors. This should be done by the ground-water specialist (or designee) soon after all required data are compiled in the GWSI data base, and before they are published or submitted to the NAWQA National Archive data base. Ultimately, it is also important for all potential users of the required GWSI data to know when data entry is as complete as possible. Therefore, the last entry in the GWSI data base for a well used by NAWQA should be a note (remark) by the Study-Unit ground-water specialist (or designee) to the effect that data entry is complete to extent possible, and that the data have been checked (table 1, General data, Remarks [C806]: "NAWQA GWSI data entry completed as verified by [name] on [mm/dd/yyyy]").

\section{Specific Guidance on Selected Site, Well, and Subsurface Data}

For the purposes of discussion, the required GWSI data are considered under one of three main data categories--General Site data, Well Use and Construction data, or Geohydrologic data (table 1). Specific guidance on the collection, documentation, and compilation of data in each of these groups is provided (in table 1, and for selected GWSI data, in the report sections that follow). The guidance is presented to maintain a given level of accuracy, consistency, and detail in the GWSI data provided by different Study-Unit teams.

\section{General Site Data}

Required general site data include that which identifies a site, and its location in relation to common USGS, political, and geographic boundaries (table 1). From the viewpoint of NAWQA objectives, and among the required general data, accurate horizontal (latitude and longitude) location and related data (table 1 , general data, $\mathrm{C009}$ through $\mathrm{C036}$ ) are among the most important data to obtain.

Accurate location data serve many purposes. They increasingly are being used to identify and obtain other geographically referenced data, such as high-resolution land-use imagery, in the vicinity of the well. But the accuracy of data obtained in relation to well location data depends heavily on the accuracy of the latter. In addition, accurate location data combined with currently (1998) available GPS units make it possible to rapidly relocate wells, which otherwise can be a time-consuming task.

Horizontal location data also are used for other purposes--to identify a well's location in relation to subsurface (aquifer) or political (District, State, and County or Township) boundaries associated with the well. Finally, location data are frequently requested by individuals outside the NAWQA Program to design studies or relate water-quality data from these wells to other ancillary information. 
The NAWQA Program needs accurate horizontal location data, and, with selected GPS units, has the means to obtain them. Study-Unit teams are to collect, document, and compile horizontal location data in accordance with procedures that will provide accurate data that can be stored in the GWSI data base (table 2). This is to be done for any installed or selected wells that either require a site record be established in GWSI; or that require well location data in a GWSI record be checked, and if necessary, corrected. This implies that methods used to determine and record the location (latitude and longitude) of each NAWQA well must meet specified data-quality criteria (table 2). It also implies that wells already installed or selected by a Study-Unit team need to have location measurements retaken if these data are not available as specified. Data-quality criteria generally can be met by selected types of PLGR's (table 3), which should be obtained through the USGS GPS-PPS Coordinator.

\section{Well Use and Construction Data}

Well use and construction data (table 1, well data) include data on site and water use, and well construction characteristics--borehole, well, casing, and open (screened)-interval depths and casing, and screen materials used. Other data required are used to document that the well is indeed adequate for continued use in relation to the NAWQA groundwater studies (Land-Use, Study-Unit, or Flowpath) for which it was initially installed or selected (see Appendix A; item 6, table 6). Most of these data, however, also can aid in the interpretation of waterquality data because they identify well or subsurface materials that come in contact with ground water, or subsurface conditions that affect groundwater quality.

The type of well (table $1 ; \mathrm{C} 024$, use of site) is important to data interpretation. On the one hand, a drinking-water supply well provides information on the potential occurrence and distribution of contaminants in ground water, commonly at depth, that currently is being consumed. On the other hand, a shallow observation well, coupled with accurate data on landscape features, provides data on the potential occurrence and distribution of contaminants associated with a given land use and cover, for ground water which commonly reflects recent recharge, is not directly consumed, but in time could move to depths where water is being pumped for consumption.

Table 2. Guidance on the collection and storage of horizontal (latitude and longitude) location data for wells used in the National Water-Quality Assessment Program

[NAD83, Navigational (horizontal) Reference Datum of 1983; GWSI, Ground-Water Site Inventory: LULCFS December-1997 version of Land-Use and Land-Cover Field Sheet; PLGR, Precision Lightweight Global Receiver

\section{WELL-LOCATION DATA AND MEASUREMENT CRITERIA ${ }^{\mathrm{a}}$}

Use method accurate to within less than half a second ( 16 meters). ${ }^{b}$

Record latitude and longitude to nearest tenth of a second.

Estimate accuracy of location data (to nearest meter).

Use NAD83 reference datum as basis for measurements.

Record all of the above: (a) in margins (or on revised) GWSI form and (b) on the (D97) LULCFS. ${ }^{c}$

a. Initially record data in margin of or on revised GWSI form, and in an electronic postscript file until modifications to the U.S. Geological Survey's GWSI data base are made to allow storage of the location data as measured. Include latitude and longitude, to the nearest tenth of a second, accuracy estimate in meters, the reference datum used, the use of PLGR to obtain data, and serial number of unit used.

b. Use precision lightweight global receiver available from U.S. Geological Survey Global Position Systems Coordinator.

c. During processing of LULCFS, location data provided are compared to well-location data obtained from registered imagery used to describe landscape in vicinity of well. 


\section{Table 3. Accuracy of Precise Lightweight Global Receiver (PLGR) Units}

[M. Ikehara, U.S. Geological Survey, written commun., 1997, Sacramento, Calif.; m, meter; s, second]

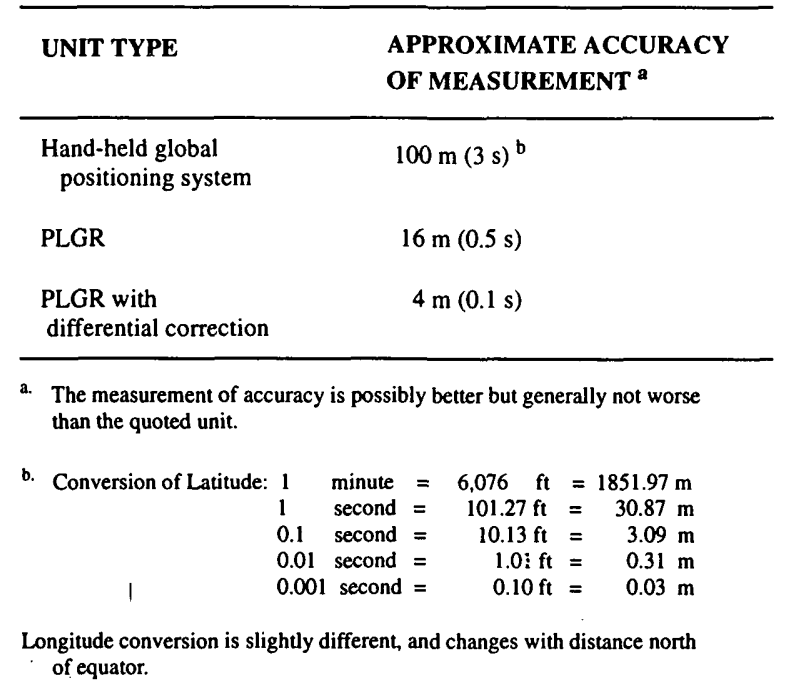

Well depth (table 1, C028), or other required depth-related data ${ }^{4}$ can directly correlate to the age of the ground water being sampled, and inversely correlate to detections of pesticides, volatile organic compounds, or other modern (post-1960) contaminant residues that accompany recently recharged ground water (Koterba and others, 1993; Kolpin, 1997). In addition, well depth and static water-level depth also are used to identify relevant lithologic data required for each well (table 1 , geohydrologic, primary contributing unit).

Except for well depth and static water-level elevation, most of the required well data need to be collected only once, and generally do not change in value with time. Water-level elevation and well depth, however, could vary with time. For this reason, use of these data for interpretive purposes implies that the measurement of the static water level at the time water-quality samples are collected (table 1, C237) is preferred over a measurement made at some other time (for example, table 1 , C30); which in turn, is better than no measurement at all.

4. Other depth-related data include depth of the open (screened) interval of the well from either the land surface (table $1, \mathrm{C083}$ ) or below the static water-level elevation (table 1, computed from [C083 - $\mathrm{CO} 30$ (or C237)]).
In the case of well depth, Lapham and others (1995) recommend measurements of this parameter be repeated at some regular interval, for example, at least once in each high-intensity phase of a StudyUnit investigation. Such measurements provide one of the few quality-control measures to verify that the length of the open (screened) interval is not changing, possibly because of the collapse or siltation of sediments into the well. Such processes could alter the pattern of ground-water flow, and, hence, the quality of the water, that enters the well.

\section{Geohydrologic Data}

The geohydrologic data identify the aquifer (locally and regionally), and an individual unit (vertical section) in that aquifer (hereafter referred to as the primary contributing unit), that provides water to the well (table 1, geohydrologic data). Aquifer identification at the local or national scale is important to those seeking information on selected ground-water resources or wells located in selected ground-water areas. To obtain this information, however, it is critical that the aquifer nomenclature used be consistent within and among Study-Unit teams. By the same token, identification of the primary contributing unit provides local geologic and lithologic data that can be useful in the interpretation of water-quality data, such as the identification of natural sources for selected trace elements or other chemical species that affect water quality. But this is possible only if the identification and description of the primary contributing unit is done in a consistent manner and using a consistent nomenclature. Therefore, GWSI guidelines are provided for each geohydrologic parameter (in table 1, geohydrologic data, and the discussion below).

\section{Aquifer Identification}

The aquifer that contains the well is identified in relation to local and national nomenclatures through the use of several GWSI parameters (table 1, geohydrologic data: C714, C713, and C311). The relevant local aquifer is determined on the basis of (1) the horizontal (geographical) location of the well, (2) the vertical location of the open (or 
screened) interval of the well, and (3) the locations of local aquifers in the vicinity of the well. The latter should be defined on the basis of the locally recognized and supported (District) system of aquifer classification, delineation, and nomenclature.

There are two additional requirements for the local nomenclature used. The chosen local aquifer name must have an approved GWSI code (table 1, C714 and C093). Otherwise, the Study-Unit Team obtains an approved code through the District or Regional Ground-Water Specialist, as appropriate.

The chosen local aquifer name must be listed as a sub-aquifer (for lack of a better term) in the Principal Aquifers data base of the USGS Office of Ground Water. This allows the Study-Unit team to identify and record the name of the Principal Aquifer (C311) that contains this local aquifer. Otherwise, the Study-Unit team must establish this association through the USGS Coordinator of the Principal Aquifer data base.

\section{Primary Contributing Unit-Definition and Lithologic Description}

To obtain lithologic data, it is necessary to define the relevant volume of earth material in the vicinity of each well. For each NAWQA well, the relevant volume of lithologic material is that which contributes all (or most) of the water to the open (or screened) interval of the well. This volume can consist of one or more lithologic units, and is defined as the primary contributing unit (table 1, C304).

Description of the primary contributing unit requires one GEOH record in the GWSI data base. ${ }^{5}$ This is preferred to the approach that requires each lithologic unit be identified as to whether it is the primary or a secondary unit, which can be difficult to do, and that collectively requires multiple GEOH records. The single-record approach also provides lithologic data that are easily retrieved and utilized.

Given NAWQA well installation or selection guidance has been met, and that information generally is lacking on the origin, movement, and rate of ground-water flow to the well, it is assumed that the primary contributing unit is a simple, cylindrical volume of lithologic materials within $500 \mathrm{~m}$ of the well that at least contains that part of the single open (or screened) interval of the well which lies in saturated material.

To better identify the vertical extent of the primary contributing unit, the Study-Unit team should use knowledge about the type of aquifer in which the well is located, where in the aquifer the well is located, and whether it appears the water being withdrawn is relatively recently recharged (fig. 1 and table 4).

Once the vertical dimensions of the primary contributing unit are determined, they are used to identify the volume of lithologic material that needs to be described. The actual description of these materials is then developed from either one of two sources. In some cases it will be derived from the appropriate vertical part of the well (borehole) lithologic log, where the latter was obtained at the time the well was selected or installed. In other cases it will be obtained from the extrapolation of other lithologic data sources.

Extrapolation of lithologic data from sources other than the well log can be done if it appears reasonable. For example, if a fine-scale $(1: 24,000)$ map of the local surficial geology or lithology is available, and it is known subsurface conditions are reasonably uniform, then the 500 -m cross-sectional area and identical vertical dimensions of the primary contributing unit can be used with this type of map to obtain a lithologic description. Similarly, if borehole data from a nearby well are available, and extrapolation appears warranted, data from that borehole can be used. But data extrapolation is not warranted from gross-scale ( $1>24: 000)$ maps, particularly if subsurface conditions are known to be fairly heterogeneous. When secondary sources of data cannot reasonably be used, only a general lithologic description should be provided, and a detailed description should not be attempted (table 1, geohydrologic data, C096 and C097, respectively).

5. The Study-Unit team creates the geohydrologic sequence record (GWSI, Geohydrologic Data (R90); Record Type (748) = GEOH) for each well. It should be the first sequence record and one for the primary contributing unit (table 1, Record sequence Number $(C 721)=001$; Contributing Unit $(C 304)=P$ ). If multi-records approach is used, then the required data for the primary contributing unit is stored independently. These data will be requested by the National NAWQA Program. 


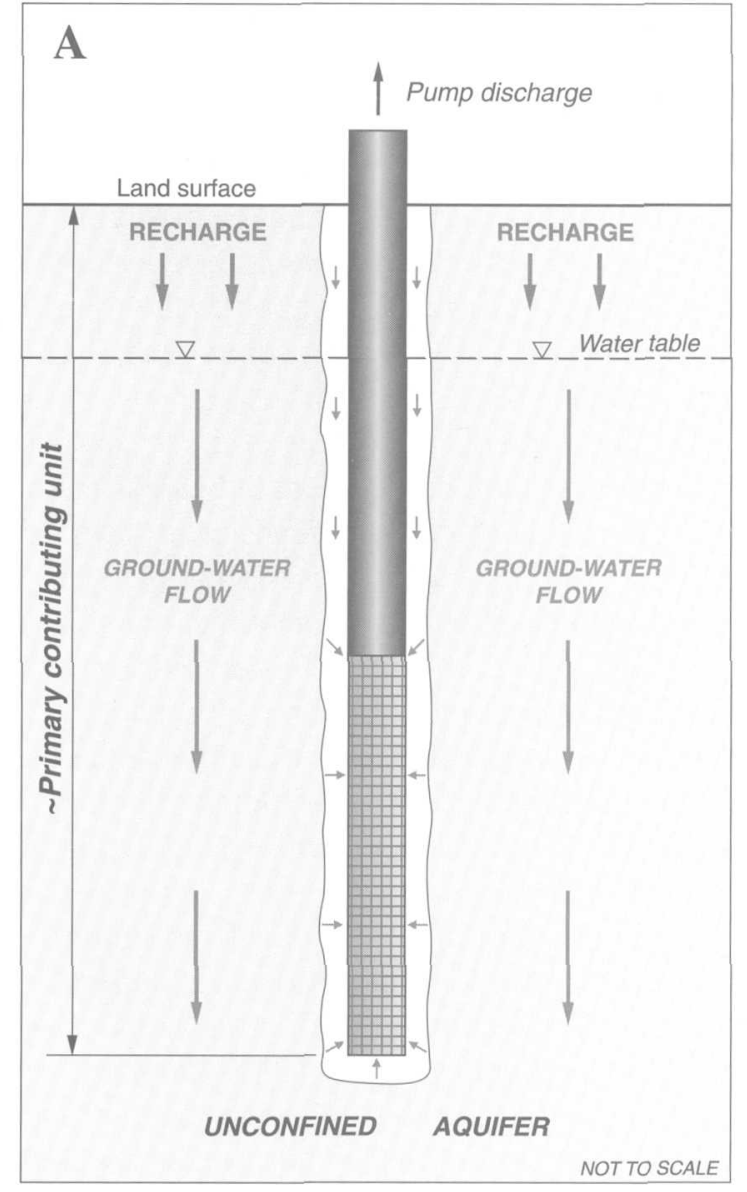

Shallow well in an unconfined aquifer and in ground-water-recharge zone. Age and quality of ground water sampled indicates that well withdraws relatively recent recharge whose quality is determined in part by land use and cover characteristics.

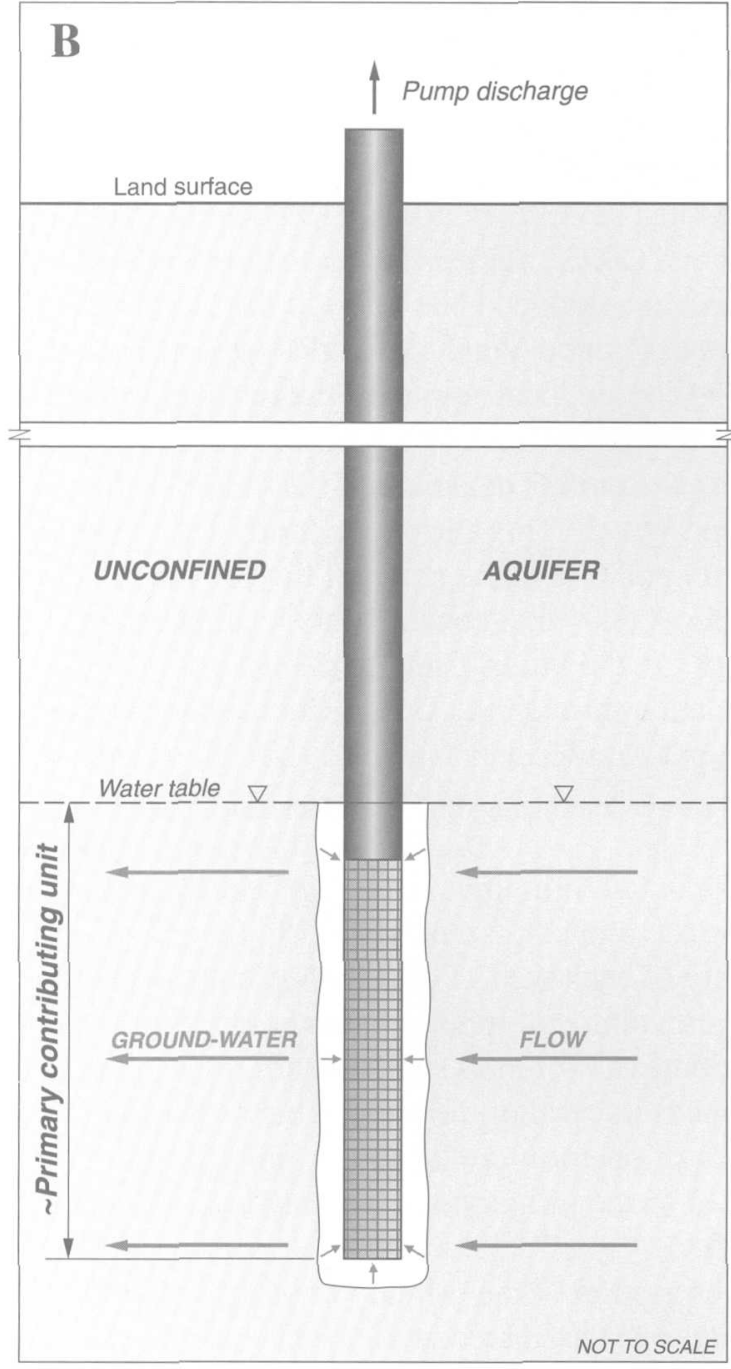

Deep well in an unconfined aquifer with regional pumpage exceeding recharge (mining ground water). Age and quality of ground water indicates that well withdraws relatively old water whose quality mainly is determined by subsurface conditions.

Figure 1. Definitions of the primary contributing unit for an observation well pumped at low-rate pump discharge (no major change in ground-water-flow pattern): four examples with different hydrogeologic and well settings.

[Because lithologic data often are not available below base of screened (or open) interval (borehole) of observation wells, primary contributing unit generally terminates at base of screened or open interval.] 


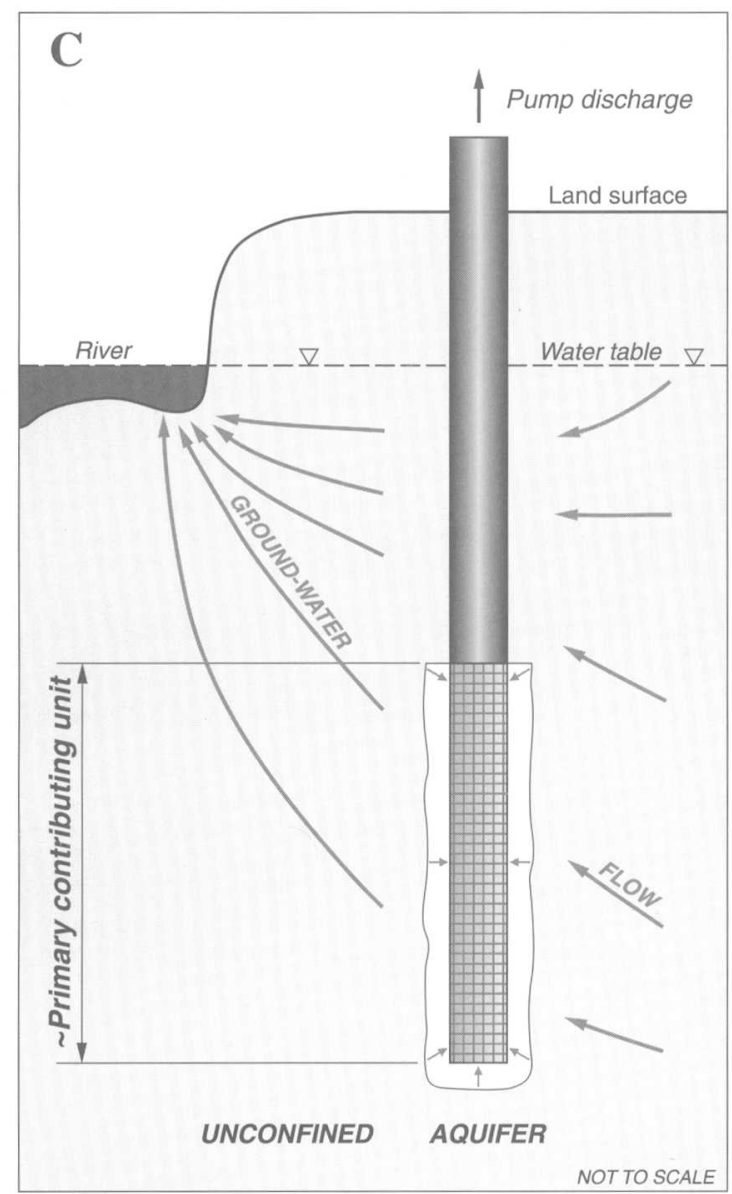

Well in an unconfined aquifer and in ground-waterdischarge zone. Age and quality of ground water indicates that water is relatively old and that quality is determined by subsurface conditions. [Screened (open) interval of well could be shallow or deep.]

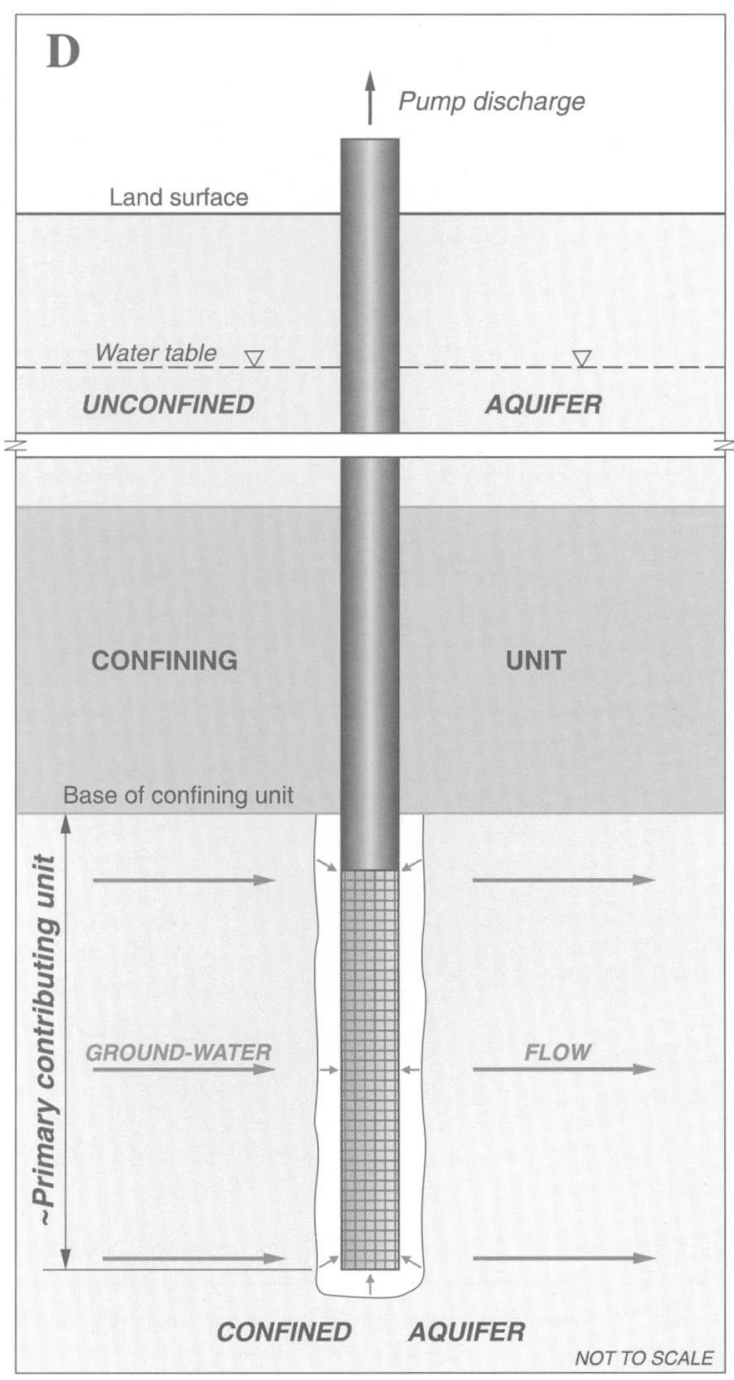

Well in a confined aquifer. Age and quality of water withdrawn from well indicates that quality mainly is determined by subsurface conditions. [Screened (open) interval of well could be shallow or deep.]

Figure 1. Definitions of the primary contributing unit for an observation well pumped at low-rate pump discharge (no major change in ground-water-flow pattern): four examples with different hydrogeologic and well settings.

-- Continued. 
Table 4. Guidance to determine the vertical extent of the primary contributing unit

VERTICAL DIMENSION OF CONDITIONS AND EXAMPLES FOR WHICH DIMENSION IS VALID
PRIMARY CONTRIBUTING UNIT
(FEET)

Depth to top of unit (C091)

Land surface ${ }^{\mathrm{a}}$, otherwise see below.

Depth to confining unit, otherwise see below.

Depth to water in well (C237, or other estimate) or to top of open (screened) interval, whichever is shallowest, otherwise see below.

Depth to water in well (C237, or other estimate) or top of open (or screened) interval, whichever is at deepest depth.

Depth to bottom of unit (C092)

Bottom of open (screened) interval (C084); otherwise see below.

Bottom of well or borehole, whichever is deepest. ${ }^{d}$
Water quality determined in part by landscape activities. ${ }^{b}$ Examples: Observation well that is:

(1) located in recharge area of unconfined surficial (water-table) aquifer, and

(2) has top of open (screened) interval located at shallow depth (below water table).

Water-supply well located in similar aquifer whose pumping rate creates major draw-down around the well. Irrigation well located in similar aquifer where irrigation is heavy in the vicinity of the well.

Water quality is not determined by landscape activities. ${ }^{b}$ Examples: Well with open or screened interval that lies below a well-defined confining unit, and the depth to water in the well is less than the depth to the base of the confining unit. Many drinking water or industrial supply well in areas that have contaminated surficial aquifers are located in underlying confined aquifers.

Water quality is not determined by landscape activities ${ }^{c}$, and well is located in recharge area. Example: Observation wells that are:

(1) located in recharge areas of unconfined surficial (water-table) aquifers, and

(2) have the top of their open (screened) interval located at depth (below water table) in aquifer.

Water-supply wells located at depth in similar aquifers whose pumping rates either do not result in appreciable drawdown, or historically have mined ground water to extent that water levels lie well below the land surface.

Water-quality not determined by landscape activities ${ }^{c}$, and well is located in discharge area. (Local information is available to indicate that direction of ground-water flow is from deeper to shallower depths in vicinity of well).

a. Except for reclaimed (mine spoils or tailings) used as soil, the primary contributing unit does not include a description of the soil, which is a landscape feature (Appendix A, item 5). If however top of contributing unit is land surface, assume $\mathrm{C} 091$ is zero feet.

b. Water quality is affected by landscape activities if samples from well indicate nitrates.elevated, pesticides or volatile organic compounds detected, acidity or trace-element concentrations elevated (for example, from mining or irrigation); or if age data indicate water sampled is modern (a chlorofluorocarbon or tritium result that indicates water possibly was recharged within last 50 years). If water-quality data indicate overlying "confining" unit is not truly confining, top of contributing unit is the land surface, and "confining" unit is considered as just another unit in the primary contributing unit. When sample quality or age data indicate ground-water quality is not affected by landscape activities, assume it mainly is determined by geochemical conditions.

c. Age of ground water is a primary factor that can be used to identify this situation.

d. Assumes well and borehole depth differ from each other, and from the depth to bottom of the open (or screened) interval of well. In general, limit is borehole depth because lithologic data seldom will be available for well below this depth. 
Whether just the general lithologic description (C096) is provided, or the general and detailed lithologic descriptions are provided (C096 and C097, respectively), the general description should give the best single description of the primary contributing unit possible on the basis of a single four-letter code (for examples, see table 5). In the case of the detailed description (C097), the lithologic description consists of multiple lithologic codes in conjunction with codes that describe selected physical and chemical characteristics of the lithologic materials found in the primary contributing unit.

For consistency, guidance on selecting the appropriate lithologic codes for the general lithologic descriptor (C096) follows:

(1) Well is located in predominantly one type of rock or unconsolidated material--either in (a) hard (consolidated) rock (often with most of the primary contributing unit in regolith or other highly fractured parts of that rock, and drawing from water-filled fractures (natural or installation-induced), solution channels, bed separations, or other types of secondary porosity; or (b) unconsolidated materials (with most of the primary contributing unit in alluvium, and drawing water from open pores, a form of primary porosity). In either case (a) or (b), the general descriptor (C096) should identify the type material (such as limestone, sandstone, granite, or unconsolidated sedimentary materials) and not just its physical nature (such as regolith, rock, rubble, boulders, sand, or alluvium). Use the best appropriate GWSI-approved code to define the rock type.

(2) If the primary contributing unit is composed of more than one rock type, or of rock and unconsolidated sediments, the "General" undifferentiated classification GWSI code that best reflects the combined lithologic units is used. For example, if the lithologic sequence contains mainly sedimentary units, such as sandstone, shale, and coal; then the lithologic code for undifferentiated sedimentary rock would be used (table 5, SDMN); and
(3) If the major rock type in the primary contributing unit does not have an approved GWSI code, request a code from the District GWSI manager rather than using a common generic descriptor.

The second parameter (table 1, geohydrologic data, C097) provides for a detailed lithologic description of the primary contributing unit (for example, see table 6). This description is limited by GWSI to 123 characters. Therefore, lithologic units are identified with approved GWSI codes (for example, see table 5). For each unit code specified, one also indicates its thickness, porosity, and potential as a possible source material for selected chemical species. 'These descriptive items are combined as follows:

(1) Use first 7 characters (in C097) to describe if primary contributing unit is either unconfined "U NONE;" or confined "C XXXX;", where U is unconfined, which is followed by a blank space, then the word "NONE", and then a semicolon; and where $C$ is for confined, which is followed by a single blank space, and then $\mathrm{XXXX}$, and finally a semicolon. The XXXX implies an approved four-letter code is required if the top of the primary contributing unit is defined by a confining layer. (For example, from table 5, one could specify caliche $(\mathrm{CLCH})$, clay (CLAY), or silt and clay (STCL) as the confining-unit material). Avoid use of generic (less-meaningful) terms for the confining layer, such as "hardpan" (table 5, HRDP).

(2) Use up to the next 115 characters to describe lithology as follows (see table 6, example):

A. Describe each major lithologic unit (with 4-letter GWSI-approved code, followed by a single blank space) in order of occurrence, from the top to the bottom of the primary contributing unit .

B. Immediately after each unit listed, indicate its thickness to the nearest foot, followed by a single blank space, then a description of the unit's porosity, followed by a blank. Define porosity as follows: primary (use P), secondary (use S) ${ }^{6}$, or both (use B). (For karst use K).

\footnotetext{
6. Examples of secondary porosity include separated vertical joints or horizontal beds, fractures (stress or fault, natural or induced) solution cavities, or lava tubes.
} 
Table 5. Selected lithologic descriptors for the primary contributing unit to a well ${ }^{a}$

[Modified from Ground-Water Site Inventory Data Base, GWSI]

\begin{tabular}{|c|c|c|c|c|c|c|c|}
\hline \multicolumn{6}{|c|}{ ROCK } & \multirow{2}{*}{\multicolumn{2}{|c|}{$\begin{array}{c}\text { UNCONSOLIDATED } \\
\text { Alluvial and Glacial }\end{array}$}} \\
\hline \multicolumn{2}{|c|}{ Igneous } & \multicolumn{2}{|c|}{ Metamorphic } & \multicolumn{2}{|c|}{ Sedimentary } & & \\
\hline Lithology & Code & Lithology & Code & Lithology & Code & Lithology & Code \\
\hline $\begin{array}{l}\text { Undifferentiated } \\
\text { (igneous) }\end{array}$ & IGSN & Undifferentiated & MMPC & Undifferentiated & SDMN & $\begin{array}{l}\text { Undifferentiated } \\
\text { (alluvium) }\end{array}$ & ALVM \\
\hline $\begin{array}{l}\text { Undifferentiated } \\
\text { (volcanic) }\end{array}$ & VLCC & & & & & $\begin{array}{l}\text { Undifferentiated, } \\
\text { glacial }\end{array}$ & GLCL \\
\hline anorthosite & ANRS & gneiss & GNSS & bentonite & BNTN & boulders & BLDR \\
\hline basalt & BSLT & marble & MRBL & caliche & $\mathrm{CLCH}$ & boulders and sand & BLSD \\
\hline diabase & DIBS & quartzite & QRTZ & chalk & CHLK & boulders, silt, clay & BLSC \\
\hline diorite & DORT & schist & SCST & chert & CHRT & clay & CLAY \\
\hline gabbro & GBBR & serpentine & SRPN & claystone & CLSN & clay, some sand & CLSD \\
\hline granite & GRNT & siltstone & SLSN & coal & COAL & cobbles & СOBB \\
\hline granite, gneiss & GRGN & slate & SLTE & conglomerate & CGLM & cobbles and sand & $\cos D$ \\
\hline rhyolite & RYLT & & & dolomite & DLMT & cobbles, silt, clay & $\cos c$ \\
\hline \multirow[t]{19}{*}{ syenite } & SYNT & & & dolomite and shale & DMSH & drift & DRFT \\
\hline & & & & evaporite & EVPR & gravel & GRVL \\
\hline & & & & gypsum & GPSM & gravel and clay & GRCL \\
\hline & & & & lignite & LGNT & gravel, cemented & GRCM \\
\hline & & & & limestone & LMSN & gravel, sand, silt & GRDS \\
\hline & & & & limestone dolomite & LMDM & gravel, silt, clay & GRSC \\
\hline & & & & limestone and shale & LMSH & hardpan & HRDP \\
\hline & & & & mudstone & MDSN & loam & LOAM \\
\hline & & & & peat & PEAT & loess & Loss \\
\hline & & & & sandstone & SNDS & muck & MUCK \\
\hline & & & & sandstone and shale & SDSL & mud & MUD \\
\hline & & & & saprolite & SPRL & outwash & OTSH \\
\hline & & & & shale & SHLE & overburden & OBDN \\
\hline & & & & travertine & TRVR & rock & ROCK \\
\hline & & & & tuff & TUFF & rubble & RBBL \\
\hline & & & & & & sand & SAND \\
\hline & & & & & & sand and clay & SDCL \\
\hline & & & & & & sand and gravel & SDGL \\
\hline & & & & & & sand and silt & SDST \\
\hline
\end{tabular}


Table 5. Selected lithologic descriptors for the primary contributing unit to a well ${ }^{a_{--} \text {Continued }}$

\begin{tabular}{|c|c|c|c|c|c|c|c|}
\hline \multicolumn{6}{|c|}{ ROCK } & \multirow{2}{*}{\multicolumn{2}{|c|}{$\begin{array}{c}\text { UNCONSOLIDATED } \\
\text { Alluvial and Glacial }\end{array}$}} \\
\hline \multicolumn{2}{|c|}{ Igneous } & \multicolumn{2}{|c|}{ Metamorphic } & \multicolumn{2}{|c|}{ Sedimentary } & & \\
\hline \multirow[t]{6}{*}{ Lithology } & Code & Lithology & Code & Lithology & Code & Lithology & Code \\
\hline & & & & & & sand, gravel, clay & SGVC \\
\hline & & & & & & sand, some clay & $\mathrm{SNCL}$ \\
\hline & & & & & & silt & SILT \\
\hline & & & & & & silt and clay & STCL \\
\hline & & & & & & till & TILL \\
\hline
\end{tabular}

a. Codes listed are as of November 1997. Obtain current code list from GWSI electronic support file of codes. If code needed is not listed, contact District GWSI manager to obtain approved code. For general lithology (C096), use the code that best describes the overall rock type. For the detailed lithologic description field (C097), also use those code (s) that convey the most specific information on each type of lithologic material. For example, if a hardpan layer is present, but it consists chiefly of clay, use CLAY rather than HRDP.

C. After porosity, and if valid, list within parenthesis, by code (table 7) selected trace elements or chemical species that could be found or produced by the lithologic unit, and possibly appear in ground water. If more than one species, separate by blanks. ${ }^{7}$ End this entry with a semicolon.

(3) Use the last (not necessarily 123d) character in the $\mathrm{C} 097$ descriptor field to indicate whether the data used for $\mathrm{C} 097$ mainly came primarily from the well borehole (B) or from other sources (O). ${ }^{8}$

(4) Check to ensure final code of the C097 lithologic data follows the strict code format (table 6).

\section{Multiple Contributing Units}

A conceptual model that differs from that described in the previous section (which was a simple cylinder, with a circular cross section of $500 \mathrm{~m}$ in radius, centered about the well) can be used for the primary contributing unit if information is available to better define this unit. For example, in addition to the area within $500 \mathrm{~m}$ of the well, some Study-Unit teams defined optional areas to describe landscape characteristics (see Land-Use, Management, and Other Data: Land-Use and Land Cover Field Sheet section this report). Use of such optional areas requires data be available to characterize the lithology of the primary contributing unit.

7. Only provide this information if it can be justified (see table 6, footnote).

8. Use B, if and only if the CO97-field mainly is populated from borehole data for the well being characterized. 
Table 6. Example of lithologic data and coding of data for primary contributing unit of a well

\begin{tabular}{|c|c|}
\hline LITHOLOGIC DATA AND RELATED INFORMATION & DERIVATION OF CODED INFORMATION \\
\hline $\begin{array}{l}\text { Lithologic log and description of lithologic units } \\
\text { compiled from: } \\
\text { (1) driller's notes of the borehole for the well } \\
\text { being characterized, } \\
\text { (2) subsequent visual inspection of sediment } \\
\text { samples taken during well installation } \\
\text { in an unconfined aquifer, } \\
\text { (3) published reports on the chemical composition } \\
\text { of the units encountered, and }\end{array}$ & $\begin{array}{l}\text { Primary Contributing Unit Defined: } \\
\text { The primary contributing unit is assumed to extend from land surface }(\mathrm{C} 091=0) \text { to the } \\
\text { base of the open interval, which in this case also is the well depth }(\mathrm{C} 092=\mathrm{C} 027 \text { or } \\
\mathrm{C} 028=63 \text { ) because (a) the well is unconfined with short casing, (b) all lithologic } \\
\text { units appear to be highly permeable, and (c) water-quality data indicate the water is } \\
\text { probably recent recharge (young in age and contains pesticides and elevated nitrate } \\
\text { concentrations). The several feet of well-drained sandy-loam soil and colluvium, } \\
\text { however, are not included in the lithologic description. Soil composition does not } \\
\text { appear to contribute significantly to dissolved solids including trace elements in } \\
\text { ground water. (If the "soil" actually was reclaimed overburden from a mining } \\
\text { operation, it would be included). }\end{array}$ \\
\hline $\begin{array}{l}\text { (4) selected water-quality data (elevated nitrates, } \\
\text { occurrence of pesticides, and estimated } \\
\text { age of water): }\end{array}$ & \\
\hline $\begin{array}{l}\text { Description for well used by NAWQA (well form): } \\
\text { "From the land surface, well is cased to a depth of } \\
10 \mathrm{ft} \text {, then an open borehole for another } 53 \mathrm{ft} \text {. In this } 63-\mathrm{ft} \\
\text { interval, and from land surface to the bottom of the well } \\
\text { (and borehole)) are: } 3 \mathrm{ft} \text { of well-drained sandy-loam soil; } \\
5 \mathrm{ft} \text { of colluvium (a mixture of mainly sand, gravel, and } \\
\text { clay); } 50 \mathrm{ft} \text { of cemented (calcareous) sandstone, with many } \\
\text { vertical joints, and some bed separations (particularly at } \\
\text { points of contact with other units); } 3 \mathrm{ft} \text { of highly fractured } \\
\text { partially-decomposed shale that overlies a } 2 \text { - } \mathrm{ft} \text { thick } \\
\text { fractured seam of high-sulfur bituminous coal. } \\
\text { Water-quality data indicate the presence of nitrates } \\
\text { and pesticides, and that sampled water was } \\
\text { possibly recharged about } 10 \text { years before sample } \\
\text { collection (chlorofluorocarbon age)." }\end{array}$ & 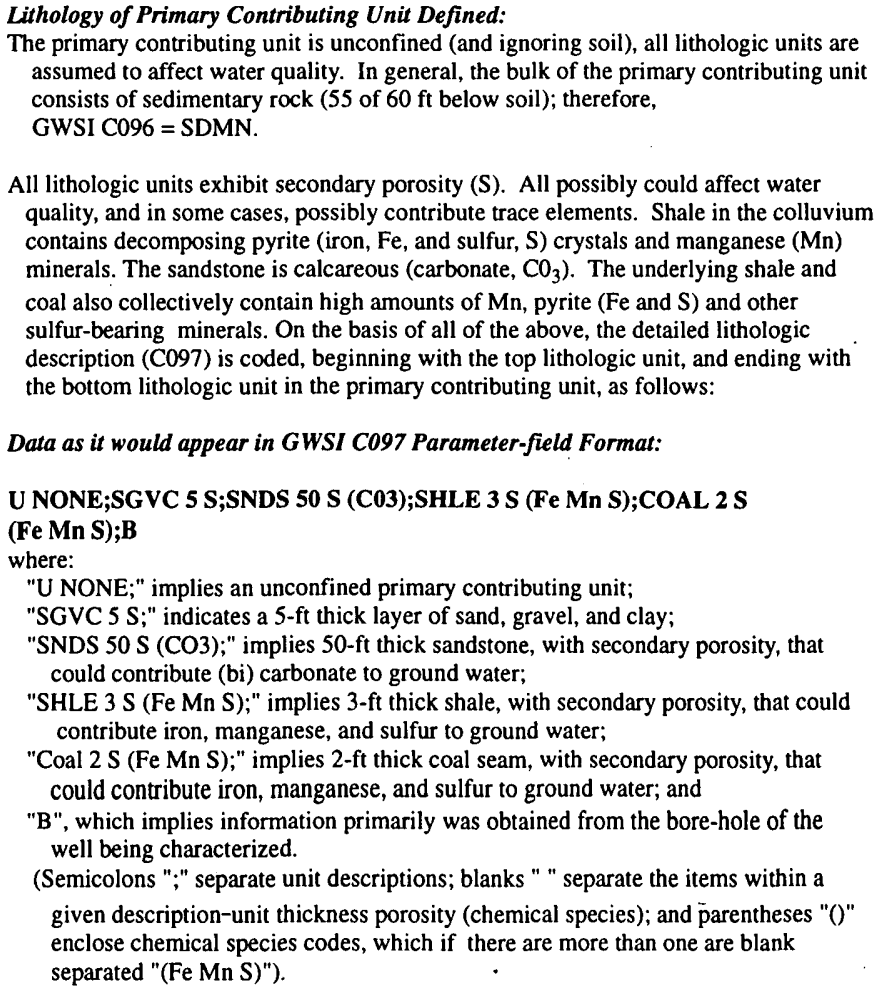 \\
\hline
\end{tabular}


Table 7. Selected geologic and lithologic features to incorporate in the description of the primary contributing unit of a well

\begin{tabular}{ll}
\hline FEATURE & EXAMPLE (S) \\
\hline Potential lithochemical sources & Granite, sandstone, shale, dolomite, or limestone \\
Rock type, lithochemical source: & \\
(a) Carbonates (Alkalinity) & Limestone, dolomite, or other. \\
(b) Sulfides (Acidity) & Pyrite, and other sulfur-bearing minerals, such as high or low-sulfur coal. \\
(c) Radiochemical-bearing minerals & Radon, radium-226 or -228, and uranium. \\
(d) Metal and other trace-element bearing minerals & Abundant in selected trace-elements. \\
\hline
\end{tabular}

a. T.L. Miller. U.S. Geological Survey, June 1997, National Water-Quality Assessment Memorandum; specification of trace elements of interest: Aluminum (Al), Arsenic (As), Boron (B), Barium (Ba), Cadmium (Cd), Copper (Cu), Cobalt (Co), Chromium (Cr), Fluoride (F), Iron (Fe), Mercury (Hg) Iodide (I), Manganese (Mn), Molybdenum (Mo), Nickel (Ni), Lead (Pb), Radon (Rn), Radium (226 or 228, use Ra), Selenium (Se), Silver (Ag), and Strontium (Sr), Uranium (U), and Zinc (Zn). Also include potential sources for acidity such as reduced Sulfur (use S), and alkalinity, such as carbonate or bicarbonate (use $\mathrm{CO}_{3}$.

Study-Unit teams can use drillers' or other logs or sediment-core data from the well, and consult local sources (geologists, geochemists, and geological and water-quality reports) for information to aid in identification of possible natural trace-element sources from log and core data. Water-quality results, however, (specifically measurements of above elements in the water-quality sample collected from the well) should not be used to imply that natural sources for these elements occur in the primary contributing unit. This would preclude doing the converse. Namely, analyzing water-quality data obtained from wells in relation to the lithologic data obtained from wells to determine if distribution and occurrence in ground-water can be related to the presence (or absence) of lithologic source materials, where the latter have been independently identified as being in the vicinity of the well, and possibly a source of trace elements, on the basis of $\log$, core, and other related reference data.

The conceptual model for the primary contributing unit described in the previous section also assumes that NAWQA guidance on well installation or selection is met, and, therefore, the installed or selected well has only a single open (or screened) interval that lies wholly within a single aquifer (Lapham and others, 1995). These conditions are not met if (1) the well has more than one open (screened) interval, or (2) if the interval length is such that it either (a) spans two aquifers, or (b) incorporates two or more distinctly separate major contributing units in a single aquifer that markedly differ in their lithology.

If multiple contributing units are present, the Study-Unit team at least must judge which interval, aquifer, or unit (part of the lithologic sequence) is designated as the primary contributor of water to the well, and which part (s) are secondary con- tributors of water to the well. The geohydrologic data required must then be described in relation to all (primary and secondary) contributing units using different GEOH sequence records.

Multiple contributing units require a series of additional sequence records, one for each secondary contributing unit. Each secondary unit must be identified (C304 = S, instead of $P$ ), and each given a unique, successive record $(\mathrm{C} 721=$ either 002 , or $003, \ldots$, respectively). For each secondary unit, one must specify its vertical extent and describe the lithologic materials in a manner similar to that used for the primary contributing unit (table 1 , geohydrologic data: C091, C092, C096 and C097). In addition, if this situation occurs, then the StudyUnit team must document that this situation occurred in the GWSI data base (through multiple $\mathrm{GEOH}$ records) and in its re-evaluation of the well 
on the basis of design criteria (see Appendix A, item 6, table 6). Multiple record descriptions are avoided, however, if wells that meet NAWQA guidelines are installed or selected.

\section{Land-Use, Management, and Other Data: Land-Use and Land Cover Field Sheet}

The NAWQA Land-Use Studies (LUS) provide data on shallow ground-water quality in relation to a targeted land use (Gilliom and others, 1995; Leahy ${ }^{9}$ ). Shallow ground water that moves deeper into an aquifer can be withdrawn for water supplies, which commonly are characterized by NAWQA (Gilliom and others, 1995; Leahy ${ }^{9}$ ) through Study or Sub-Unit Surveys (SUS). When an LUS is geographically located within an SUS, and wells for both studies are located in the same aquifer, the water-quality data obtained from both studies can be used to not only determine the occurrence and spatial distribution of nutrients, pesticides, trace elements, volatile-organic chemicals, or other selected compounds in ground water, including that used for water supplies, but also allow one to determine possible relations between conditions at and below the land surface and the quality of ground water, including that of water supplies. When water-quality-data collection is repeated for these nested studies, changes in water quality (including water supplies) can be assessed in relation to changes in the landscape conditions. All of this assumes, however, that initial and subsequent changes in land use and land management also have been observed, described, measured, and documented.

Landscapes similar to those associated with NAWQA studies can be described in relation to different types of land use and cover (Anderson and others, 1976). If these descriptions are to assist in ground-water-quality data interpretation, however, then data on land use and cover in the vicinity of LUS and SUS wells need to be obtained in a quantitative, consistent, and unbiased manner at selected time intervals. If this is done each time a particular NAWQA Study Unit is in it's HighIntensity Phase (Gilliom and others, 1995), it would generally imply that water-quality data, and landscape data in the vicinity of each well, for a given LUS will be obtained about once every 10 to 20 years. For data collected on this time cycle to be useful to NAWQA and others it must be stored electronically in a consistent manner in a central location.

The remainder of this report describes the guidance developed by the NAWQA Program to be used to collect, document, and compile landscape data for LUS and SUS wells. Included in this description are the results of a pilot study, and of a review of that study and other related USGS studies, which are the basis for understanding the scientific and technical information that led to the development of this guidance.

\section{National Water-Quality Assessment Program Pilot Study}

Results of several USGS studies (table 8) indicate that landscape data can be collected and documented in a consistent and accurate manner, and can be used to aid in the interpretation of ground-water-quality data. These studies have several factors in common, including the use of internally consistent (1) definitions of land use, land cover, and management practices, (2) remote data (aerial or other imagery) to aid in the identification and description of different landscape features, and (3) quantitative methods to compute the extent, occurrence, or otherwise quantify selected landscape features.

Collectively, these studies demonstrate that within a given distance from a well (roughly 400 to 2,000 m), significant correlations exist among selected ground-water-quality measures and landscape features. The studies also illustrate that some differences in the strength of these correlations occur as a function of the size, shape,

9. P.P. Leahy, U.S. Geological Survey, December 1994, National WaterQuality Assessment Program Memorandum: Additional guidance on the design and conduct of NAWQA ground-water study-unit surveys and reporting of results. 


\section{Table 8. Examples of U.S. Geological Survey studies that relate differences in land use and cover to ground-water quality}

[NAWQA, National Water-Quality Assessment Program; LUS, land-use study; SUS, Study (Sub)-Unit Survey; ${ }^{\circ}$, degrees; GVC, Great Valley Carbonate; VR, Valley and Ridge, mi, mile; m, meter]

\section{STUDY}

NAWQA: Delmarva Peninsula Study Unit in Delaware. Maryland, and Virginia (Banks and Koterba, 1992, and Koterba and others, 1993).

\section{MAJOR FINDINGS}

Quantified local land use and cover (within 1/4-mi) of each of 100 widely distributed SUS wells in Atlantic Coastal Plain alluvium.

Results:

Percentage of wells surrounded by a given land use (agricultural, urban, woodlands and wetlands, and barren) almost identical to the percentage of that same land use relative to the total survey area.

"Chemical signatures" derived from ground-water-quality data for agricultural, urban, and natural (mainly forested) areas correlated to the pre-dominant land use and cover around wells.

Probability of pesticide detection in ground water directly correlated to predominant land use and soil type around well, and inversely correlated with distance from the water-table elevation down to the top of the well screen. (Latter possibly indicative of ground-water age.)

NAWQA: Red River of North Study Unit, Minnesota and North Dakota (Cowdery, 1997)

\author{
Identified probable recharge area, and quantified land use and cover in this area, for each of \\ 58 wells that comprised two different agricultural LUS (Sheyenne Delta and Otter Tail \\ Outwash aquifers of Red River Valley Lake Plain). \\ Results: \\ On the basis of land uses found in the recharge areas, the water-quality data are possibly \\ biased--reflect more the effects from chemicals used on row crops, than those associated with \\ grassland and pasture land uses. Bias appears minor.
}

NAWQA: Potomac River Basin Study Unit in Maryland, Pennsylvania, Virginia, and West Virginia (Ferrari and Ator, 1995; Ator and Ferrari, 1997; and Ator and Denis, 1997).

Toxic Substances Hydrology Program: Midcontinent Study in central United States (Kolpin, 1997).
Quantified local land-use and cover [within 1/4-mi, 1/2-mi, and upgradient of well (semicircle and $90^{\circ}$ wedge)] of each of 120 wells for 2 SUS and 2 LUS).

For GVC agricultural LUS, landscape data defined on basis of $1 / 4-\mathrm{mi}$ buffer indicated that the targeted agricultural land use was well represented by the selected wells.

For VR agricultural LUS, landscape data indicated that water-quality data could reflect different land uses, and possibly underestimated agricultural effects. Agricultural lands are relatively small in size, occur chiefly in valley bottoms, and are often interspersed with urban (rural) and forested lands.

For VR area and both SUS, correlations among water-quality measures and land-use features generally were significant regardless of location, size, or shape of area used to define landscape. Correlations improved in some cases if landscape was defined on the basis of an upgradient, rather than circular area, and further improved in some cases if landscape was defined for an upgradient $90^{\circ}$ wedge. The magnitude of improvements in correlations however, generally were small. For the GVC area, correlations did not improve using upgradient, instead of a circular, areas to define landscape features possibly because surficial topography is not a reliable indicator of the probable direction of ground-water flow to wells.

Quantified local land use and cover (within 200-m, 500-m, 1,000-m, 1,500-m, 2,000-m and upgradient) of each of 100 randomly selected production or monitoring wells distributed throughout parts of the Midcontinental region of the Nation.

Results:

Except for the 200-m radius buffer, significant correlations were noted between landscape data and water-quality data in relation to all buffer sizes, with the differences in the strength of correlations as a function of buffer size generally being minor.

Strongest correlation between nitrate concentrations and landscape features occurred when latter defined on basis of 500-m buffer. Except for urban land use defined on the basis of the $500-\mathrm{m}$ buffer, strongest correlation between pesticide detections and most land-use variables occurred when latter defined on the basis of large $(1,000-\mathrm{m}$ or $1,500-\mathrm{m})$ areas. 
Table 8. Examples of U.S. Geological Survey studies that relate differences in land use and cover to ground-water quality--Continued

\begin{tabular}{ll}
\hline STUDY & MAJOR FINDINGS \\
\hline New Jersey (Barringer and others, 1990) & $\begin{array}{l}\text { Quantified local land use (within } 100 \mathrm{~m} \text { up to within } 1,000 \mathrm{~m} \text { ) for selected wells in the } \\
\text { Cretaceous Potomac Group, and Raritan and Magothy Formations of New Jersey. } \\
\text { Results: } \\
\text { Detection of volatile organic compounds is best correlated with land-use data defined } \\
\text { for areas within } 600 \text { to } 800 \mathrm{~m} \text { of well. } \\
\text { Illustrate and discuss problems that can be encountered for small or large buffer sizes that } \\
\text { relate to uncertainty in land-use data, data closure, sparseness of some data, and } \\
\text { spatial autocorrelation. }\end{array}$ \\
$\begin{array}{l}\text { Toxic Substances Hydrology Program: } \\
\text { Colorado, Connecticut, Florida, } \\
\text { Nebraska, New Jersey, and } \\
\text { New York (Cain and others, 1989) }\end{array}$ & $\begin{array}{l}\text { Quantified land use in six different areas of the nation with different techniques because of } \\
\text { differences in the type and quality of available land-use and cover data among these areas. }\end{array}$ \\
& $\begin{array}{l}\text { Results: } \\
\text { Correlated selected water-quality and land-use.data for each area. Differences in the quality and } \\
\text { type of landscape data available precluded a combined data assessment for all six areas. }\end{array}$ \\
\hline
\end{tabular}

and location of the area that is characterized (table 8).

In 1995, results from these studies, some of which were preliminary at that time, prompted Lapham and others $(1995, \mathrm{p}$. 52) to note that methods used for landscape descriptions developed during the pilot phase of the NAWQA Program (Hardy and others, 1989, p. 6-7) could require revision. In 1996, a pilot study was initiated to revise the guidance for landscape data collection. ${ }^{10}$

\section{Design and Implementation}

This pilot study was conducted by members from six NAWQA Study Units, with the assistance of the CPG for land-use and cover data, and support from the National Synthesis Teams (See Acknowledgments Section). Pilot-study objectives included revisions of landscape data-collection methods and the Land-Use and Land-Cover Field Sheet (LULCFS), testing of these revisions in the field, and estimating the resources required to quantify selected landscape and other features.

As part of the pilot revision, consensus had to be reached on several aspects of landscape characterization. This included (1) the shape, size, and location of the areas (s) to characterize in the vicinity of each well, (2) the type of imagery to use

10. T.L. Miller, U.S. Geological Survey, June, 1996. National WaterQuality Assessment Program Memorandum with Commentary and General Discussion of the Pilot Approach to Characterize Well Installation and Construction and Land Use and Cover for NAWQA Wells. 
to expedite and document landscape descriptions, and (3) the identification of potential point sources of contamination in the area (s) selected and in relation to the imagery used.

Shape, Size, and Location of Landscape Area (s) Ideally, the rate and direction of ground-water flow should determine the shape and size of the recharge area to the well, which in turn is the ideal landscape to characterize (for example, see Cowdery, 1997). This approach generally requires information on ground-water flow, however, that commonly will not be available for the 7,000 to 8,000 thousand individual wells at which NAWQA will be collecting water-quality data over one complete study cycle. For many of these wells, no actual data will be available on local ground-waterflow rates, and topography generally will be the only readily available information from which one can assume a probable direction of ground-water flow to the well.

In the absence of hydrologic information, empirical studies provide the best indication of the area that should be characterized in the vicinity of a well (table 8). These studies demonstrate that for wells in surficial aquifers (such as NAWQA LUS wells, and those SUS wells where it appears land use affects the quality of water withdrawn from the well), a simple circular area around a well can be used. Such a buffer has repeatedly been shown to be a useful boundary for landscape definition for NAWQA and other studies (table 8).

The reason the circular buffer has been successful for NAWQA LUS studies probably relates to the manner in which these studies are designed. Their focus generally is on surficial aquifers, and the use wells installed by or for the Study-Unit team (Gilliom and others, 1995). Potential well sites throughout areas of the targeted land use initially are identified (by latitude and longitude) with a spatially stratified randomselection process (Scott, 1990). For each randomly determined point, however, the actual drilling site not only must reflect the targeted land use, but must be accessible in order to install the well. Local topography often is used to select a potential drilling site that meets both these conditions. Assuming that drilling can be done at the chosen LUS site, the well is generally installed to place the screened (open) interval of the well at a shallow depth (within a few meters below the water-table elevation) in the surficial aquifer. On the basis of this approach, it appears reasonable that the recharge area, and hence, the landscape area of interest, would be included in a fairly large (400 to 2,000-m circular) area around that well.

That the landscape of interest can be approximated by a simple circular buffer for NAWQA SUS wells is not as apparent as in the case of LUS wells. Most SUS wells are generally selected water-supply wells ${ }^{11}$ (Gilliom and others, 1995). Water-supply wells commonly have a screened or open interval located at depth in the aquifer (Alley, 1993). Therefore, for a simple circular area around the well to be a valid approximation of at least part of the recharge area, the pumping rate and frequency for the supply well must be sufficient to draw water that recharged in the vicinity of the well. That this does occur is supported by the findings of Ferrari and Ator (1995) and Kolpin (1997), which each demonstrated that landscape data defined on the basis of circular buffers around water-supply wells can be related to the quality of water withdrawn from these wells.

Noncircular areas have been used for landscape characterization, and include "upgradient" semicircles and 90-degree wedges, and flowdetermined recharge areas (Ator and Denis, 1997; Cowdery, 1997; and Kolpin, 1997). But the lack of comparative data between these areas and circular areas (Cowdery, 1997), and the lack of marked improvements in correlations between landscape features defined on the basis of these areas and circular areas for the comparisons that have been made (table 8), imply additional studies are needed.

11. P. P. Leahy, U.S. Geological Survey, December 1993, National WaterQuality Assessment Program Memorandum: Programs and Plans: Additional guidance on the design and conduct of NAWQA groundwater Study-Unit Surveys and reporting results. 
In relation to future studies, one distinct advantage of a circular area over almost any other type of area for the initial landscape characterization of a well is that once it is characterized almost any type of upgradient landscape area (semicircle, 90-degree wedge, or other area) can be generated from the circular area. The converse is not true.

Another advantage provided by the initial classification of the 500-m circular area is one of insurance if the identification of upgradient areas becomes a problem. Situations can arise that make it difficult to identify the upgradient area--for example, when there is no discernible topographic relief, or the direction of shallow ground-water flow does not relate to local topography (table 8; results for the Great Valley Carbonate LUS).

For the NAWQA Pilot Study, a 500-m radius was chosen for the circular area. Empirical studies indicate that use of a $500-\mathrm{m}$ circular area is either (1) optimal (table 8, Kolpin, 1997; nitrates in general, and pesticides in urban land use), (2) falls within the range of buffer sizes one could consider nearly optimal (table 8, Ferrari and Ator, 1995; nitrates and pesticides in agricultural and general land-use areas), or (3) is close in size to what is considered optimal (table 8, Barringer and others, 1990; volatile organic compounds in mainly urban areas). A buffer of this size also would include smaller recharge areas derived on the basis of simple topography (such as a semicircle or 90-degree wedge) or on the basis of estimates of the direction and rate of local ground-water flow (Cowdery,1997).

Because of the need for comparative studies, some Pilot-Study teams also wanted the option to characterize an additional upgradient area. To exercise this option, however, implies that some type of assessment must be made of the direction and possibly rate of ground-water flow in the vicinity of the well (see above).

\section{Type of Imagery}

Remote imagery is essential to aid landscape characterization of large areas that cannot be viewed in their entirety from a single point (such as at the wellhead). This imagery also has to be capable of being field verified, corrected, scanned and digitized. To provide accurate information, and limit field-correction and processing times and costs, imagery obtained has to be of high resolution. It also should reflect the landscape conditions at about the time water-quality samples are collected from the well. After field-verification, it is important to recognize that such imagery is an important document and must be archived.

On the basis of the desired imagery characteristics, Study-Unit teams were encouraged to use high-resolution black and white photographs (36-in. x 36-in., 1: 8,000; or 18-in. x 18-in., 1: 20,000) obtained from the Earth Resource (s) Observation Service (EROS) National Aerial Photography Program, Sioux City, S. Dak. (Hereafter, this imagery is referred to as a National Aerial Photograph, or NAP.)

The NAP imagery was strongly recommended for several reasons. It has a resolution of about 10 meters-squared, which is excellent in that it corresponds to less than 1 percent of a 500-m circular area around a well. Black and white NAPs are easily scanned because of their high contrast. The size and scale of NAP's, particularly those that are 36-in. x 36-in., result in a scaled 500-m circular area that is physically large (3- to -4 inches in diameter), which permits accurate delineation, scanning, and digitization of individual land-use and cover areas that constitute only a few percent of the total buffer area. The NAP coverage also is available nationwide, and, for individual States, and is generally updated about every 5 years. For these reasons, the quality and availability of NAP imagery meet the long-term needs of the NAWQA Program.

Pilot-study participants also requested that guidance allow the option to use alternative imagery, provided it met certain conditions. It had to be of at least similar quality to NAP imagery, and be acceptable to the CPG for central processing.

\section{Point-Source Identification}

Previous studies (table 8) indicate the need to avoid, but still characterize, potential point sources of contamination, particularly those that might be close to the well. Contamination of ground water from such sources can override attempts to determine the effects of potential nonpoint sources of contamination associated with land-use and management practices, such as large areal applications of water (irrigation), or chemicals (fertilizers or pest control agents). 
Because NAWQA well selection or site selection for well installation is initially guided by a random selection process (Scott, 1990), potential point sources in the vicinity of wells need to be considered. Except for urban LUS, drilling sites for LUS wells in nonurban areas are selected to avoid point sources close to the well (Lapham and others, 1995, and Gilliom and others, 1995). For urban (commercial-residential) LUS wells, potential point sources need to be identified (Squillace and Curtis, 1996). For an SUS, wells initially installed because of known or suspected contamination are not to be selected, however, the selection process does not preclude the occurrence of point sources of contamination. Finally, the identification of potential point sources needs to be considered not only within the immediate vicinity of the well, but throughout the landscape area being characterized, and in relation to the resolution of the imagery used.

For practical reasons, Study-Unit teams for the Pilot Study treated potential point sources as follows:

(1) The landscape within $50 \mathrm{~m}$ of the well was characterized to ensure attention was given to the identification of potential point sources, as well as general landscape and managementrelated activities, in close proximity to the well. All information was recorded either directly on the pilot LULCFS (see for example Appendix $A$, item 3 and, as needed, item 4 or initially on a field form (fig. 2), and later transferred to the pilot LULCFS.
(2) Within the 500-m buffer, potential point sources were considered in relation to a list that was developed by the National Synthesis teams (Appendix A, item 4). This list also permits the documentation of any source not explicitly identified (Appendix A, item 4, blank spaces under appropriate subheading). Listing also was used to identify any land use and cover area on the imagery that occupied less than a few percent of the $500-\mathrm{m}$ circular buffer area, and therefore, would be difficult to accurately digitize.

\section{Method of Characterization}

The pilot study mainly employed recent (within five years of sampling date) NAP imagery of the area in the vicinity of each well in either an LUS or SUS. A colorless transparent sheet (Mylar) overlain on that imagery (an overlay), combined with visual field observations and predefined descriptions of different land uses and covers (for example, see Appendix B), were used to delineate and identify major land uses and covers within $500 \mathrm{~m}$ of each well associated with one of six different NAWQA SUS or LUS. For each well, all data were recorded on either the overlay [mainly the (coded) identity and boundaries of land uses and covers] or on the pilot LULCFS (Appendix A, item 3).

Visual observations and published information (primarily County soil maps ${ }^{12}$ ) also were used to identify selected management practices and predominant soil characteristics (within $500 \mathrm{~m}$ of well, Appendix A, items 3 and 5), and potential point sources of contamination (within 50 and $500 \mathrm{~m}$ of well, Appendix A, items 4, 5, and $6 \mathrm{~A}$ and B). The pilot LULCFS also was used to document selected well and sample-point characteristics, and re-evaluate the well for NAWQA (Appendix A, item $6 \mathrm{C}$ and, D).

\footnotetext{
12. U.S. Department of Agriculture, Natural Resource Conservation Service, County maps $(1: 24,000)$.
} 
50-m Buffer Land-use and Cover. SUID Well ID Survey date(s): NETCODE Surveyor:

\section{Comments:}

Instructions: Orient sheet so that top of circle is North.

Land-use codes, coverages (in percent), and descriptions within 50-m radius of well

\begin{tabular}{|c|c|c|}
\hline Code name & Percent & Description \\
\hline \hline & & \\
\hline & & \\
\hline & & \\
\hline & & \\
\hline & & \\
\hline
\end{tabular}

SCALE: One square block is $25 \times 25$ meters.

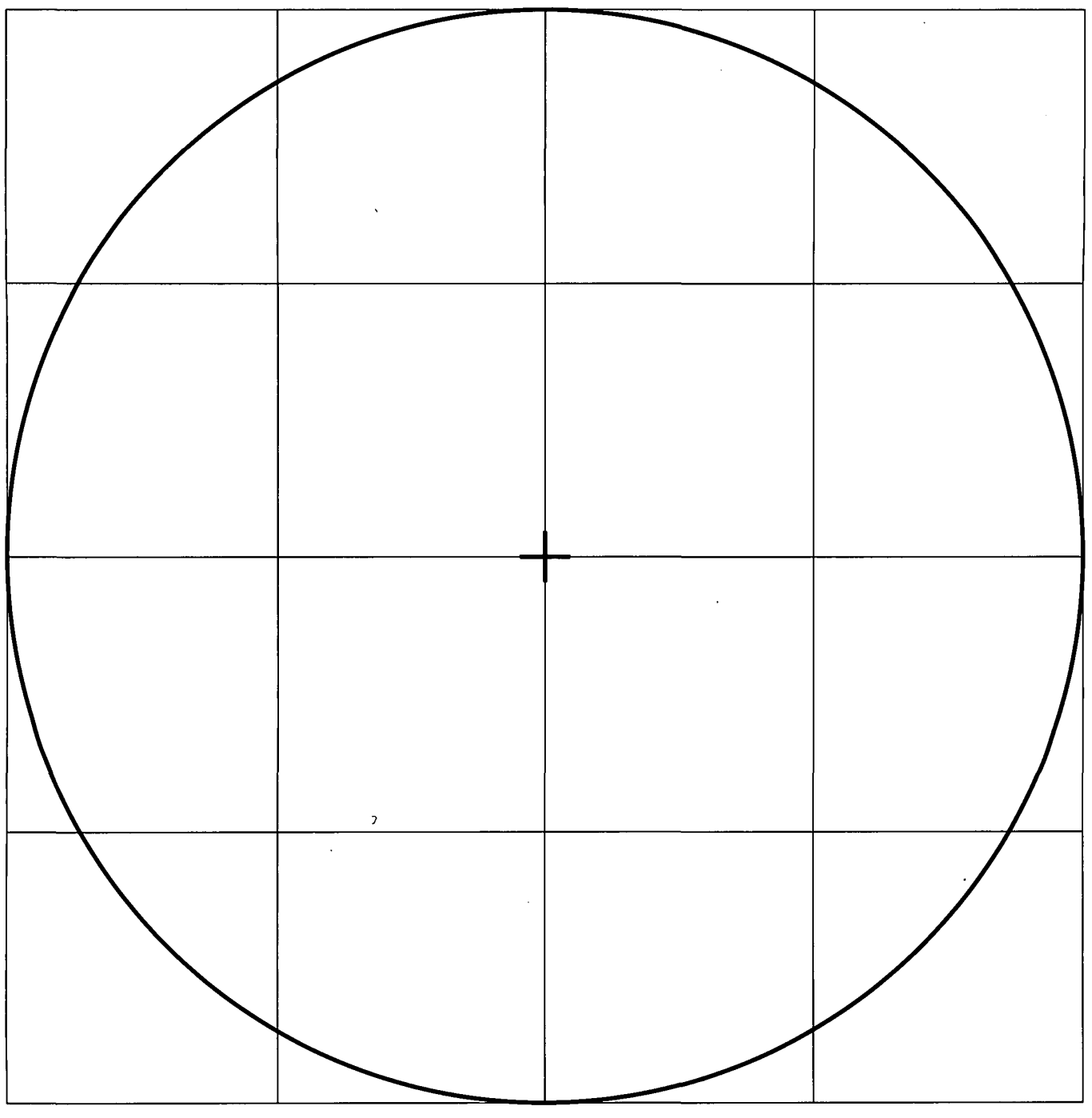

Figure 2. Field sheet for the characterization of landscape within 50 meters of the well (modified from unpublished work, Gerard J. Gonthier, U.S. Geological Survey, Little Rock, Ark.). 
After data were obtained for all wells for a given LUS or SUS, the overlay, imagery, and pilot LULCFS for each well were sent to the NAWQA CPG. The CPG scanned, registered, and digitized the imagery, added the buffer, and used the overlay to delineate the location of each identified land use and cover in this buffer. Using this digital imagery, the CPG then computed the percent coverage for each identified land use and cover in the $500-\mathrm{m}$ buffer to complete the pilot LULCFS. The CPG also reviewed all pilot LULCFS data for correctness and completeness, notified Study-Unit teams of identification or other data-entry errors, and corrected these on the basis of responses received. In addition, the CPG developed procedures to quality-control their work, and transfer data to the NAWQA National Archive data base.

\section{Results}

A brief review of the results indicates that Study-Unit teams commonly identified from 1 to 12 different land uses and covers within $500 \mathrm{~m}$ of a well. The median number per well (from five to seven different classifications per well), however, was roughly the same among the teams. Examples of typical classifications for urban, agricultural, and reclaimed (previously mined) lands illustrate that land use and cover in the vicinity of most wells is not homogeneous (one land use and cover), but commonly exhibits a moderate diversity of related land uses and covers (figs. 3, 4, and 5).

An assessment of resource requirements indicates that individual Study-Unit teams required from 88 to 334 hours to assemble and prepare materials, field-verify their imagery, and complete the pilot LULCFS for all (approximately 30) wells in either an LUS or SUS (table 9). Differences in the time required reflect differences in Study-Unit team approaches and timing of activities, and in land-use complexity.

In general, less time was required if the team incorporated the following into their approach:

(1) One individual performed a given task; but different individuals performed different tasks on the basis of their skills;

(2) Each major task (table 10) was reviewed soon after it was begun to ensure consistent and quality work, and improve efficiency (namely, avoid too detailed a classification);

(3) Overlays and pilot LULCFS's were completed and reviewed in the field on site, rather than revised and completed en masse at the end of field work; and

(4) Field work was done when vegetation was readily identifiable.

A breakdown of resource requirements for each Study-Unit team (table 10) indicates that time was spent mainly on two activities:

(1) overlay and imagery work (that to obtain imagery, prepare overlays, and, if necessary, revise overlays in the office after the completion of field work); and

(2) field work (identify land uses and point sources, primarily in the 500-m buffer).

For most teams, the resources required for the overlay-imagery work involved ordering the NAP imagery. This included identifying the most appropriate NAP for each well from flight lines. The procedure was time-consuming, often taking one individual 40 or more hours to identify NAP's for 30 wells. ${ }^{13}$

13. Although this was not counted as a resource requirement, it was certainly a factor that affected the timing of field work. Once the NAP's were ordered, it took up to six weeks for the teams to receive the photographs. Currently (1998), NAPs for a NAWQA LUS or SUS can be electronically identified and ordered from EROS in less than a day. Because NAPs are still each produced on basis of an individual order, it still can take up to 5 to 6 weeks to receive NAP's. 


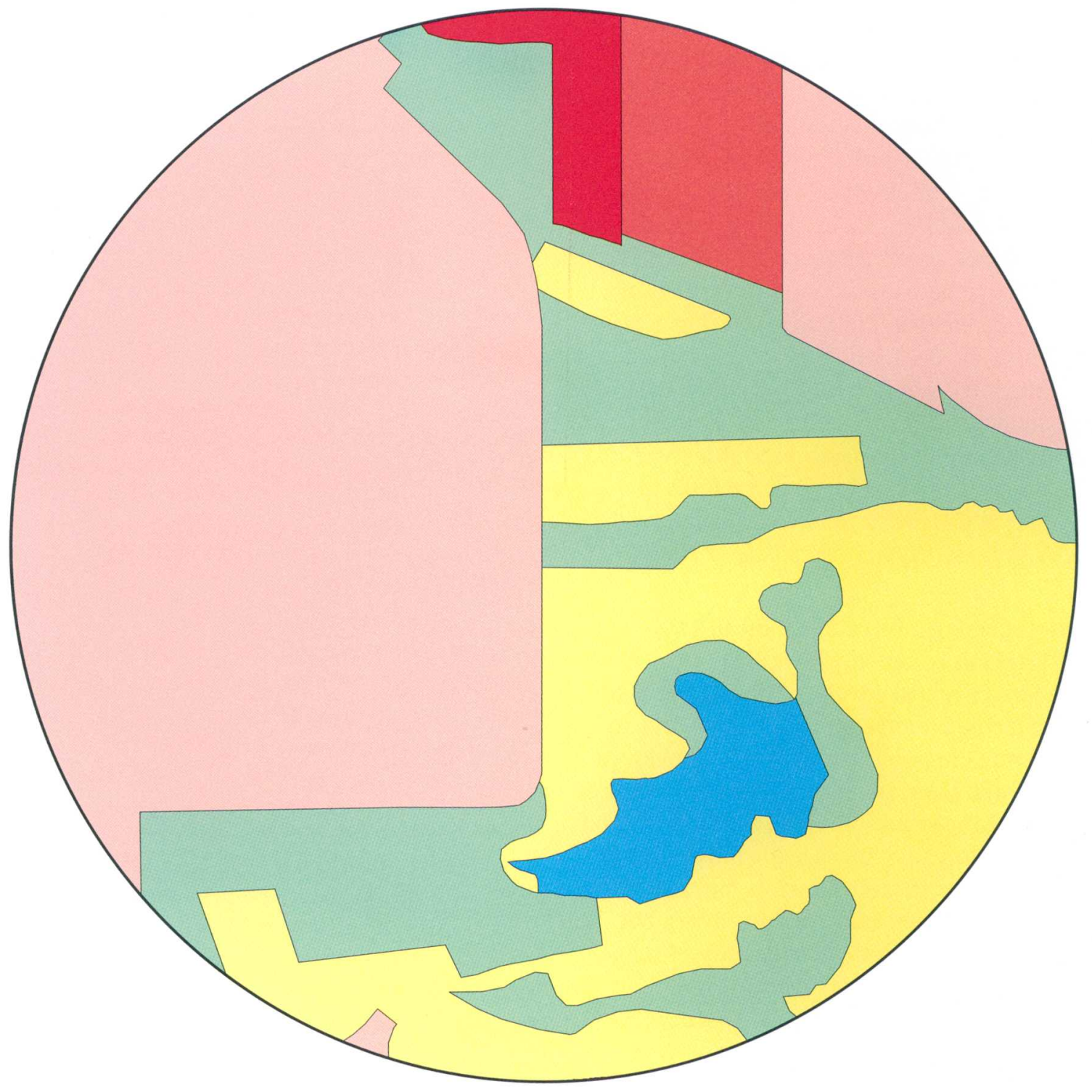

EXPLANATION

COLOR

KEY

$\square$ URBAN, HEAVY INDUSTRIAL-COMMERCIAL

$\square$ URBAN, LIGHT INDUSTRIAL-COMMERCIAL

$\square$ URBAN, SINGLE-FAMILY HOUSING

WATER, OPEN

AGRICULTURE, LIVESTOCK, MIXED, PASTURE

FOREST, UNMANAGED, DECIDUOUS

$\begin{array}{cc}\text { AREA }\left(\mathbf{m}^{2}\right) & \begin{array}{c}\text { PORTION OF } \\ \text { 500-m BUFFER (\%) }\end{array} \\ 16,357 & 2 \\ 31,983 & 4 \\ 345,174 & 44 \\ 27,573 & 3 \\ 192,390 & 25 \\ \frac{171,012}{784,489} & \frac{22}{100}\end{array}$

Figure 3. Example of a completed land-use and cover characterization of landscape within 500 meters of a well in a predominantly urban (commercial-residential) setting. 


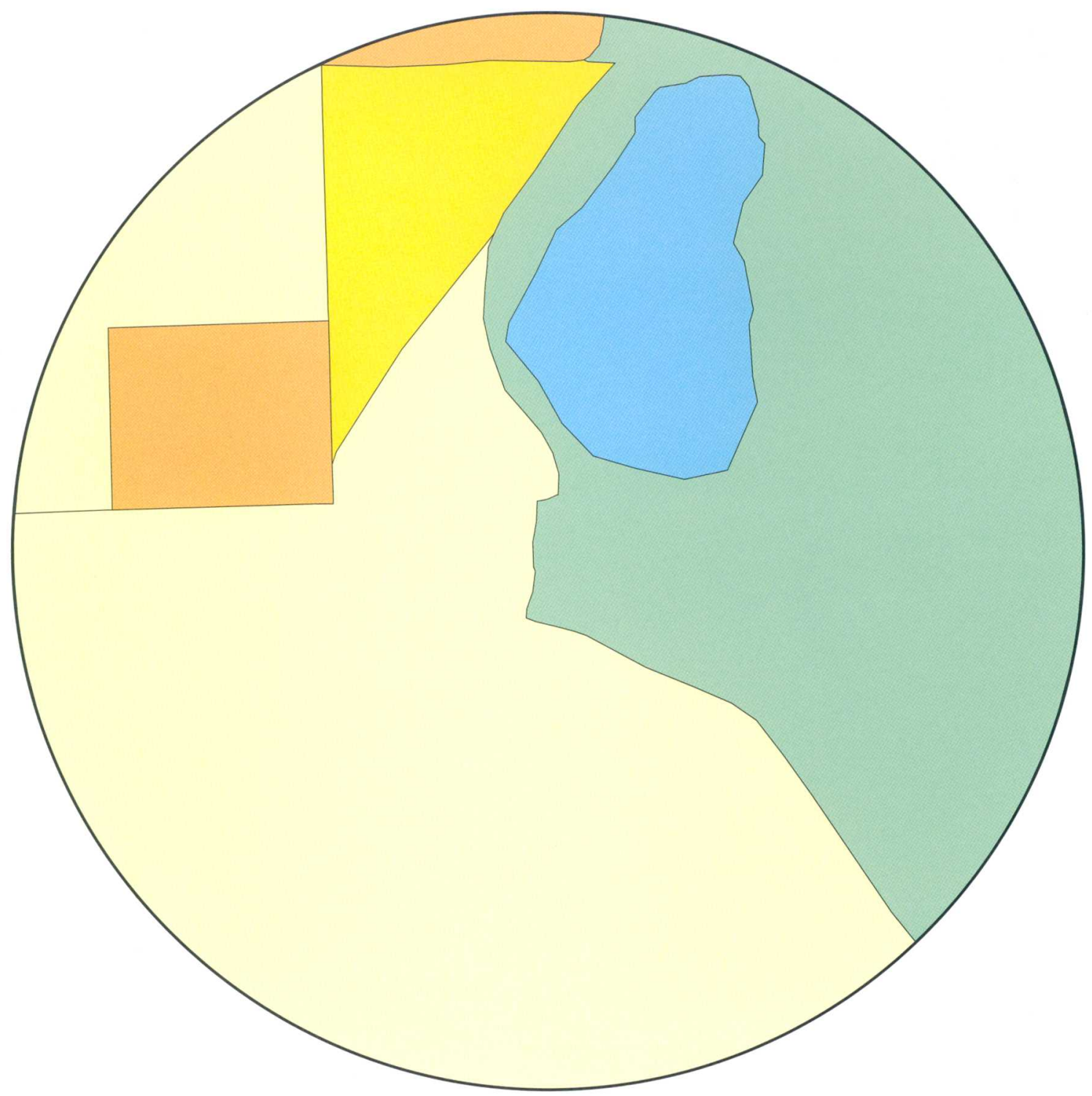

EXPLANATION

COLOR

KEY

$$
\square
$$

AGRICULTURE, ORCHARD, WALNUT

AGRICULTURE, ORCHARD, PEACH

$\square$ AGRICULTURE, RICE, DOMESTIC

WETLAND, LACUSTRINE

FOREST, UNMANAGED, DECIDUOUS

$\begin{array}{cc}\text { AREA }\left(\mathrm{m}^{2}\right) & \begin{array}{c}\text { PORTION OF } \\ \text { 500-m BUFFER (\%) }\end{array} \\ 387,397 & 49 \\ 43,549 & 6 \\ 48,740 & 6 \\ 60,550 & 8 \\ \frac{244,301}{784,537} & \frac{31}{100}\end{array}$

Figure 4. Example of a completed land-use and cover characterization of landscape within 500 meters of a well in a predominantly agricultural setting. 


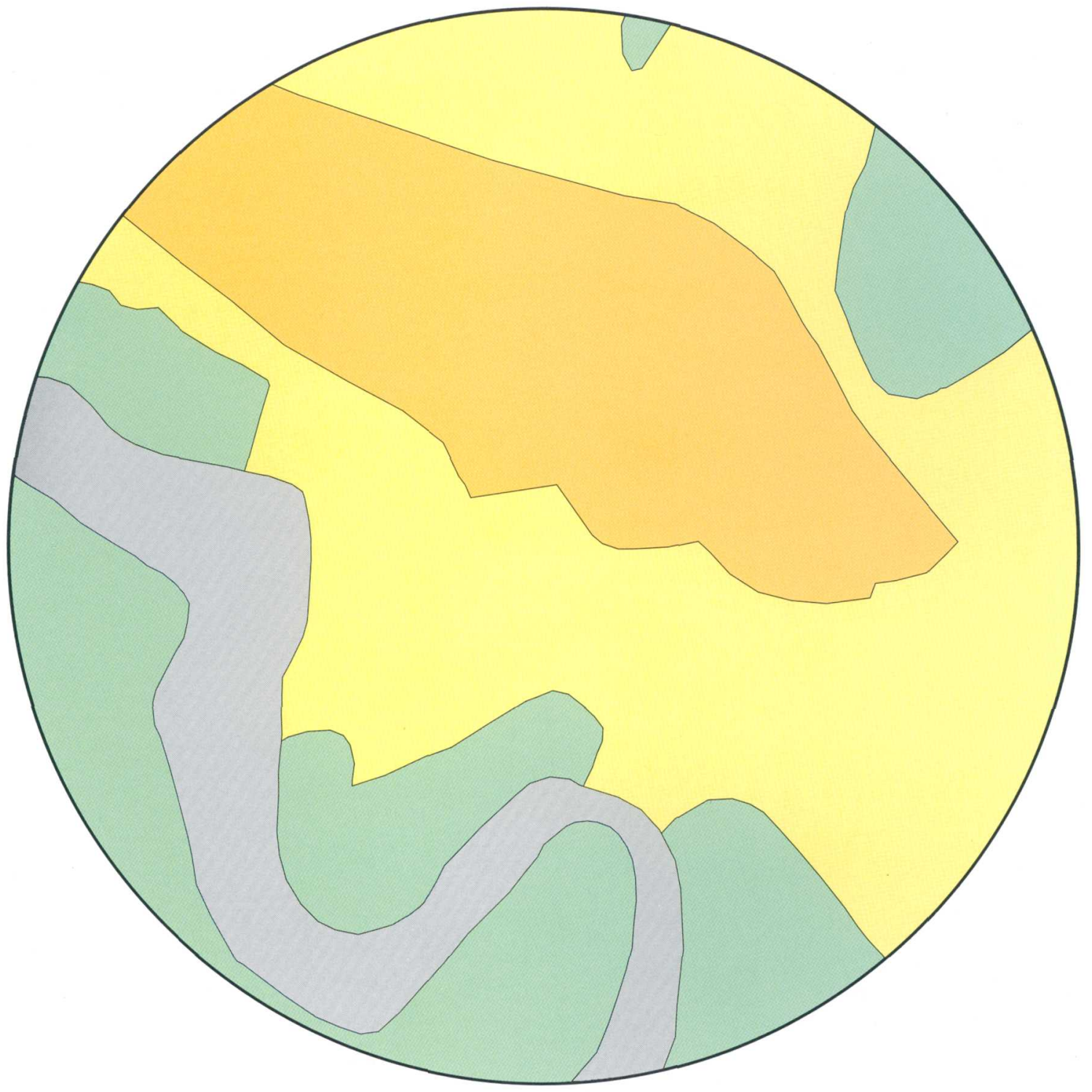

EXPLANATION

\begin{tabular}{llc}
$\begin{array}{c}\text { COLOR } \\
\text { KEY }\end{array}$ & \multicolumn{1}{c}{ LAND USE AND COVER } & $\begin{array}{c}\text { PORTION OF } \\
\text { AREA }\left(\mathbf{m}^{2}\right)\end{array}$ \\
$\square$ AG0-m BUFFER (\%)
\end{tabular}

Figure 5. Example of a completed land-use and cover characterization of landscape within 500 meters of a well in a reclaimed mining area. 
Table 9. Time required to prepare, conduct, and complete pilot landscape characterization ${ }^{a}$

[SANT, Santee River Basin and Coastal Drainages; UMIS, Upper Mississippi River Basin; LINJ, Long Island-New Jersey Coastal Drainages; MISE, Mississippi River Embayment; ALMN, Allegheny-Monongahela Basin; and SACR, Sacramento River Basin; LUS, Land-Use Study;

SUS, Study(Sub)-Unit Survey; CPG, Central Processing Group for Land Use and Land Cover Field Sheet]

\begin{tabular}{llc}
\hline STUDY UNIT & GROUND-WATER COMPONENT & PERSONNEL HOURS \\
\hline SANT & LUS, urban, 30 wells & 88 \\
UMIS & LUS, urban, 31 wells & 105 \\
LINJ & LUS, urban, 30 wells & 222 \\
MISE & LUS, urban, 30 wells & 230 \\
ALMN & SUS, 30 wells & 235 \\
SACR & SUS, 30 wells & 334 \\
\hline
\end{tabular}

a. Not included in the above resource assessment are the CPG data processing, quality-control, and compilation requirements. These required about 30 to 40 hours for one LUS or SUS. CPG resource requirements are supported at the NAWQA National Program level.

Table 10. Breakdown of total time for selected activities to complete landscape characterization

[Percent is equal to the number of hours for indicated activity divided by total number of hours required to complete all (un) listed activities $x$ 100; UMIS, Upper Mississippi River Basin; LINJ, Long Island-New Jersey Coastal Drainages; MISE, Mississippi River Embayment; SACR, Sacramento River Basin; ALMN, Allegheny-Monongahela Basin; SANT, Santee River Basin and Coastal Drainages; --, data unavailable; m, meter]

\begin{tabular}{|c|c|c|c|c|c|c|c|}
\hline \multirow{2}{*}{ ACTIVITY } & \multirow{2}{*}{$\begin{array}{l}\text { WORK } \\
\text { LOCATION }\end{array}$} & \multicolumn{6}{|c|}{ STUDY-UNIT TIME, IN PERCENT } \\
\hline & & UMIS & LINJ & MISE & SACR & ALMN & SANT \\
\hline Document well identity. & Office & 1.0 & 0.4 & 0.4 & -- & 1.7 & 2.8 \\
\hline $\begin{array}{l}\text { Obtain and document imagery, construct overlay } \\
\text { for field, and complete revision of overlay in } \\
\text { office. }\end{array}$ & Office & 55 & 54 & 33 & 33 & 21 & 46 \\
\hline $\begin{array}{l}\text { Field verify and correct imagery on overlay for } \\
\text { current land-use (in } 50 \text { and } 500 \text {-m buffers), and } \\
\text { identify potential point sources). }\end{array}$ & Field & 33 & 34 & 43 & 53 & 60 & 46 \\
\hline Identify soil types. & Office & 1.5 & 11 & 2.1 & 9.6 & 10 & 3.1 \\
\hline $\begin{array}{l}\text { Describe well and sampling locations, and } \\
\text { re-evaluate well in relation to NAWQA design } \\
\text { criteria. }\end{array}$ & Office & 2.3 & .9 & .4 & -- & 6.7 & 1.1 \\
\hline
\end{tabular}


Field work, which represented the other most time-consuming activity, generally involved one or more individuals spending 1 to 2 hours at each well. A small part of this time (often less than 15 minutes) was required to characterize the area within $50 \mathrm{~m}$ of the well. Most of the time was used to identify land uses or potential point sources within $500 \mathrm{~m}$ of the well.

The amount of time spent on the identification of land uses and potential point sources differed on the basis of the complexity of land use. If land use was complex [for example, urban or reclaimed (mined) land] teams spent a minimum of 1 to 2 hours at the site, and devoted more time to the identification of land uses than to the identification of point sources. If land use was relatively simple (for example, mainly agricultural or forested), teams spent a minimum of one-half hour to 1 hour at the site, and often had sufficient time to identify land uses and point sources. Overall, it appears that unless adequate time is planned for sites with complex land use and cover, the identification of point sources will be limited.

As part of the pilot study, Study-Unit teams and the CPG recommended changes in the LULCFS and guidance to clarify, improve efficiency, or otherwise aid in the landscape characterization (table 11). These recommendations were reviewed by NAWQA National Program as part of their review process.

\section{Review by National Synthesis Teams and Others}

During and after the pilot study, members from the National Synthesis Teams and their support group reviewed pilot-study activities, the pilot LULCFS, and guidance to complete this sheet. This review included and adopted recommendations from the Pilot Study (table 11), but focused mainly on a re-examination of the following: (1) the need to classify SUS wells, (2) the use of a 500 -m buffer area, and (3) the use of imagery other than NAPs.

\section{Study (Sub)-Unit Survey Classification}

The NAWQA National Synthesis Teams and support group members identified reasons why this characterization should be considered by each Study-Unit team on a case-by-case basis for each SUS (table 12). They also developed criteria for the Study-Unit team to determine whether or not landscape characterization should be performed, and, if performed, guidance on how it should be done.

Study-Unit teams must determine whether or not the landscape characterization for SUS wells is required on the basis of water-quality data. If these data indicate that ground water being withdrawn from most SUS wells is relatively modern (table 12), then the landscapes of all SUS wells need to be characterized.

If the landscape characterization is required, land use and cover should be described in general terms (Appendix B, SUS Definitions and Codes). In all other respects, the landscape characterization of SUS wells is done in the same manner as the characterization of landscapes for LUS wells. If landscape characterization of the SUS wells is not required, then only that part of the LULCFS that identifies the well and site and provides information on the well (including the re-evaluation of the well for NAWQA use) are to be completed for each SUS well (Appendix A, items 1 and 6).

\section{Use of 500-meter Circular Area}

In 1997, the NAWQA National (Nutrient) Synthesis team released preliminary results that show that the area within $500-\mathrm{m}$ of the well is optimal to establish relations between nitrate concentrations and selected landscape features (Bernard T. Nolan and Kerie Hitt, U.S. Geological Survey, written commun. 1997). This result is similar to that for other national studies (table 8, Kolpin, 1997), and further supports the use of this area for the landscape characterization in the vicinity of a well.

\section{Alternative Imagery}

During 1997, two studies by NAWQA support group personnel (see Acknowledgments section) evaluated the use of digital imagery in place of field-verified NAP's to characterize the landscape within $500 \mathrm{~m}$ of a well. One study used Anderson 1970's land cover data corrected for 1990 population density (Hitt, 1994). Hereafter, these data are referred to as the "GIRAS" data. The other study used thematic imagery data derived from Landsat Thematic Mapper Data by the USGS National Mapping Division Multi-Resolution Land Characteristics Consortium, and will replace the 


\title{
Table 11. Recommendations and comments from National Water-Quality Assessment Program Study-Unit teams and Central Processing Group
}

\author{
[in., inch]
}

\section{ACTIVITY RECOMMENDATIONS AND COMMENTS}

PLANNING

For a given ground-water component, integrate timing of landscape (and subsurface) ancillary data collection with that of ground-water-quality sampling to create continues series of steps to achieve the most efficient design. Ideal: Select or install wells before March of year sampling will occur; complete subsurface data compilation in GWSI data base (except for lithologic characterization) before growing season (by end of March), complete preparations for sampling (in April), finish sample collection during early part of growing season (by mid-June); for LUS, (and, if necessary, for SUS, on the basis of review of water-quality data) complete field-work on landscape characterization during latter part of growing season (by end of August); for LUS and SUS finish subsurface (lithologic) characterization, well re-evaluation, and, for LUS (and if necessary SUS), send landscape data for processing after growing season (by end of September). If necessary, work on next ground-water component to complete well selection or installation by February of next year to repeat above cycle.

For each landscape activity (preparatory, field-work, or follow-up work) preferably assign one individual to a task. Have ground-water specialist or designee review progress on that task soon after it begins to ensure consistency, and enhance efficiency, particularly if more than one person must do the work.

Plan field verification during growing season that corresponds to timing of water-quality sampling. Verification is most difficult in the fall or winter if vegetation is deciduous, fields are fallow, or both are covered with snow.

Methods to obtain NAP should be made electronically available. When planning field work, note that it takes up to six weeks to obtain NAP's after they are ordered.

If available, obtain NAP imagery of the finest-scale (36-in. $x$ 36-in.), as high-contrast black and white photographs, and particularly if areas are urban; otherwise use 18-in. $x$ 18-in. high-contrast black and white NAP. Avoid 9-in. $x$ 9-in. NAP, the resulting 500-m circular area (on overlay for NAP) will be too small to accurately delineate and digitize land-use and cover boundaries. Use of color NAP (EROS 18-in. x 18-in., or larger) requires advanced approval by CPG (see below).

Imagery other than NAP (high-contrast, black and white, 36-in. x 36-in. or 18-in. x 18-in.) must be evaluated and approved by CPG in advance. This includes NAP color prints. Alternative imagery (or photograph) could be fine in scale $(1:<20,000)$; but derived from original imagery that was not that accurate. Other quality and processing issues could arise, which are only apparent to the CPG. Send an example of any alternative imagery to CPG to test and evaluate before conducting field work. The CPG has final word on imagery suitability.

Plan to use original county maps for soils data. Use of digital soils data requires data be of high resolution, accurately registered, and referenced to same datum as well location. Well location also must be accurate. Soils data available for urban areas generally correspond to predevelopment conditions. During most urban development original soils (horizons) often are destroyed, topsoil is possibly removed, and after construction, another topsoil is possibly imported.

Report accurate well location (Well Location Data Section, in this report) and the estimate of measurement error on LULCFS. Expand radius of scaled 500-m circle on overlay by the scaled measurement error obtained for well location or by $1 / 4$-inch, whichever is greater, and characterize entire landscape in circle. CPG will correct to 500-m radius after registration, and report results for a 500-m circular area.

Attach overlay to imagery in office, not in field. Use pin punch, rather than tape. Tape holds poorly under field conditions. The CPG also noted that tape is difficult to remove without damaging imagery or overlay before scanning.

Code and draw boundaries of land uses and covers on overlay in the field and not before going to field. If land-use has changed since imagery was taken, prefield effort is wasted, and boundaries have to be corrected in field. This increases field time, and often results in a final overlay that is not clear and legible, and difficult for the CPG to scan. 
Table 11. Recommendations and comments from National Water-Quality Assessment Program Study-Unit teams and Central Processing Group--Continued

\begin{tabular}{ll}
\hline ACTIVITY & RECOMMENDATIONS AND COMMENTS \\
\hline FIELD WORK & $\begin{array}{l}\text { To save time, use good road maps, original well-location coordinates, and an accurate global positioning } \\
\text { system unit to relocate wells. }\end{array}$
\end{tabular}

Have a checklist of the equipment typically needed for LULCFS field work. ${ }^{a}$ For example, a rangefinder, accurate to distances of $50 \mathrm{~m}$ through $500 \mathrm{~m}$, is extremely useful. Have another list for each well that denotes activities to be done at well, and check off each activity in field as it is completed.

Visibility in urban areas can be limited. Plan on it. One individual simultaneously driving and searching for point sources doesn't work well; best if one drives and stops regularly; or one person drives while another simultaneously searches for potential point sources.

In the field, be consistent in classification of land uses and covers at a site and among sites, particularly if more than one person does classification. Be neat, draw legibly and accurately. Use non-smear high-contrast pencils or pens. Plan to complete overlay and LULCFS work on site to reduce the need for revisions.

Designate probable direction of ground-water flow to well on overlay or indicate this is not possible given information available.

Use caution in the identification of potential point sources solely on the basis of exterior appearances. Sometimes they are not point sources at all. (For example, dry cleaners that transport clothes elsewhere for cleaning).

Avoid detailed overclassification. Typically, delineation of a half dozen different types of land use for a 500 -m circular area is generally adequate. Except for some SUS sites, delineation of more than a dozen different land uses and covers for a single $500-\mathrm{m}$ circular area is generally overclassification. If this occurs for an LUS site, it probably is a good indication the well is not going to reflect the targeted land use.

Before leaving site in field, lift overlay by a free edge and inspect to ensure all land-use boundary areas are complete and coded, and that 500-m circular area is completely characterized. Review LULCFS to ensure all field data have been collected. Check that all equipment is secured and that all items on checklist are done (see above).

REVISIONS

Plot well-location data (converted to NAD27 datum) and 500-m circular area on clean USGS 7.5-minute quadrangle map. CPG will use written location data on LULCFS, and select two obvious reference points from map near circle which will be converted to NAD83 datum, and with original well location data will be used to accurately register NAP field corrected imagery to NAD83.

If necessary, revise (final) overlays for all sites in the office, and soon after field work is complete. At least check that codes on overlay are properly written. The most common error detected by CPG during processing was for coding. Often the error was the transposition of two or more letters in a code.

Photocopy overlay with imagery and LULCFS for each well. Before shipping materials organize them in a logical fashion--for example, collate materials by well. Simultaneously ship, heavily insured, the original imagery, the photocopy of overlay, the photocopy of the LULCFS, and the original USGS quadrangle map with well location and 500-m circular area for each and every well in the SUS or LUS to the CPG. File original overlay and LULCFS, and photocopy of imagery. They can be used to answer questions from the CPG that could arise when data are being processed.

\footnotetext{
a Basic equipment recommended by Study-Unit teams: a good road map to site, an accurate GPS to relocate well, a compass to designate North on overlay, a range finder (accurate for 50-m to 500-m distances), binoculars, a camera, an oversized clipboard or drawing board with clips, and high-contrast nonsmear fine-point lead pencils or ink pens that leave a clearly visible and continuous line on the overlay.
} 
Table 12. Reasons to characterize landscapes, and criteria to determine if characterization is necessary, for Study (Sub)-Unit Survey (SUS) wells ${ }^{a}$

\begin{tabular}{|c|c|}
\hline REASONS & CRITERIA \\
\hline $\begin{array}{l}\text { SUS design criteria do not preclude the selection of wells } \\
\text { that withdraw ground water that has been contaminated }\end{array}$ & $\begin{array}{l}\text { Characterization is done if ground water associated with most SUS } \\
\text { wells is relatively young in age (recharged within last } 50 \text { years). }\end{array}$ \\
\hline by land-use and cover conditions at the land surface. ${ }^{b}$ & \multirow{2}{*}{$\begin{array}{l}\text { Basis for determination of age: } \\
\text { (1) Regardless of the type of land use and cover in the vicinity of SUS } \\
\text { wells, can use isotope or other age data (for example tritium or } \\
\text { chlorofluorocarbons). } \\
\text { (2) In the absence of age data, and in the vicinity of most SUS wells } \\
\text { with developed land use (for example, agricultural, urban, or } \\
\text { industrial), water-quality data from these wells illustrate }\end{array}$} \\
\hline $\begin{array}{l}\text { Ground-water quality associated with wells that reflect } \\
\text { those commonly selected for SUS sometimes is } \\
\text { affected by land-use and cover conditions (Ator and } \\
\text { Denis, 1997; Ferrari and Ator, 1995; and Kolpin, 1997). }\end{array}$ & \\
\hline $\begin{array}{l}\text { Knowledge of general types of land use and cover for } \\
\text { these wells creates an independent means to determine if } \\
\text { these wells reflect a random sample (Cowdery, 1997; } \\
\text { Ferrari and Ator, 1995; and Koterba and others, 1993). }\end{array}$ & $\begin{array}{l}\text { anthropogenic effects--elevated nitrate concentrations, or } \\
\text { residues of synthetic compounds (pesticides, or volatile or } \\
\text { semi-volatile organic compounds). }\end{array}$ \\
\hline $\begin{array}{l}\text { Knowledge of the general types of land-use and cover in } \\
\text { the vicinity of these wells has aided in the identification } \\
\text { and interpretation of possible causes of contaminant } \\
\text { occurrence and its distribution in ground water (Ferrari } \\
\text { and Ator, 1995; Kolpin, 1997, and Koterba and others, } \\
\text { 1993). }\end{array}$ & \\
\hline
\end{tabular}

a. Given that water-quality data show ground water from most of these wells is modern (recharged within last 50 years or for most wells surrounded by developed land use, the water sampled contains elevated nitrate concentrations or detectable residues of pesticides, volatile organic, or other anthropogenic compounds).

b. Gilliom and others, 1995 and Leahy, P.P., U.S. Geological Survey, December 3, 1993. NAWQA Technical Memorandum: Additional guidance on the design and conduct of NAWQA ground-water Study-Unit Surveys and reporting of results. Design restrictions mainly prevent selection of wells that (a) have been poorly or inappropriately installed, maintained, or protected, (b) are inappropriately constructed for the types of water-quality samples being collected, or (c) are known or suspected to originally have been installed to determine the extent of known or suspected ground-water contamination.

GIRAS data (Gail Thelin, USGS, Sacramento, Calif., written commun., 1997). Hereafter, these data are referred to as the "TI" data.

For these comparisons with NAP field-verified data (from 1996-97), it must be noted that the GIRAS and TI data are each designed primarily to describe land use at a national scale. Neither of these data coverages is designed specifically to provide land-use data in the immediate vicinity of a well. Nevertheless, because electronic data coverages of this type are becoming increasingly available, their utility to characterize land use within $500 \mathrm{~m}$ of selected NAWQA wells was tested.

Because the NAP data obtained during the pilot study are field-verified, they best reflect ground truth at about the time water-quality data were collected from the LUS or SUS wells used in the Pilot Study. Thus, the comparison of these data to either the GIRAS or TI data was designed to answer two questions: 
(1) Can the GIRAS or TI data identify the predominant (Anderson, Level I ${ }^{14}$ ) land use within 500 meters of the well? and

(2) Can the GIRAS or TI data identify all the major (Anderson, Level I) land uses within 500 meters of the well?

For the GIRAS data, the comparison involved 60 wells, or one-third of the Pilot-Study wells, with 10 wells randomly selected from each of the 6 SUS and LUS. For the TI data, the comparison involved just 30 wells, with 10 wells randomly selected from one SUS and two LUS in areas for which TI data are available.

Results for the GIRAS data (table 13) indicate that these data correctly indicated the predominant land use within $500 \mathrm{~m}$ of a well for at least 50 to 100 percent of the wells in a given LUS or SUS. The GIRAS data also were more likely to indicate the predominant land use for a well installed or selected to reflect that predominant land use (LUS well) than a well that was selected independent of any type of land use (SUS well). But comparisons between the actual landscapes generated by GIRAS and NAP data for each of the 60 wells indicate that the GIRAS coverage often overestimated the areal extent of urban (mainly residential and commercial) land use at the expense of other land uses and covers. Because of this, the accuracy of the GIRAS data was limited to the correct identification of all major land uses at no more than 50 percent of the wells in a given SUS, and at no more than 40 percent wells in a given (urban) LUS.

Visual comparisons of the GIRAS and NAP landscape data for each of the 60 wells show four factors limit the accuracy of the GIRAS data. One factor is the difference in data resolution, which for GIRAS data is approximately a few hectares; whereas that for NAP field-verified data is about a tenth of a hectare. The GIRAS coverage often failed to identify small areas of one land use within a large area of another land use.
Table 13. Comparison of Anderson 1970's land-use data corrected for 1990 population density (GIRAS) data to National Aerial Photography, field-verified (1996-97) land-use (NAP) data for the area within 500 meters of a well ${ }^{a}$

[LINJ, Long Island-New Jersey Coastal Drainages; UMIS, Upper Mississippi River Basin; MISE, Mississippi River Embayment; SANT, Santee River Basin and Coastal Drainages; SACR, Sacramento River Basin; and ALMN, Allegheny-Monongahela Basin; LUS, Land-Use Study; SUS, Study (Sub)-Unit Survey]

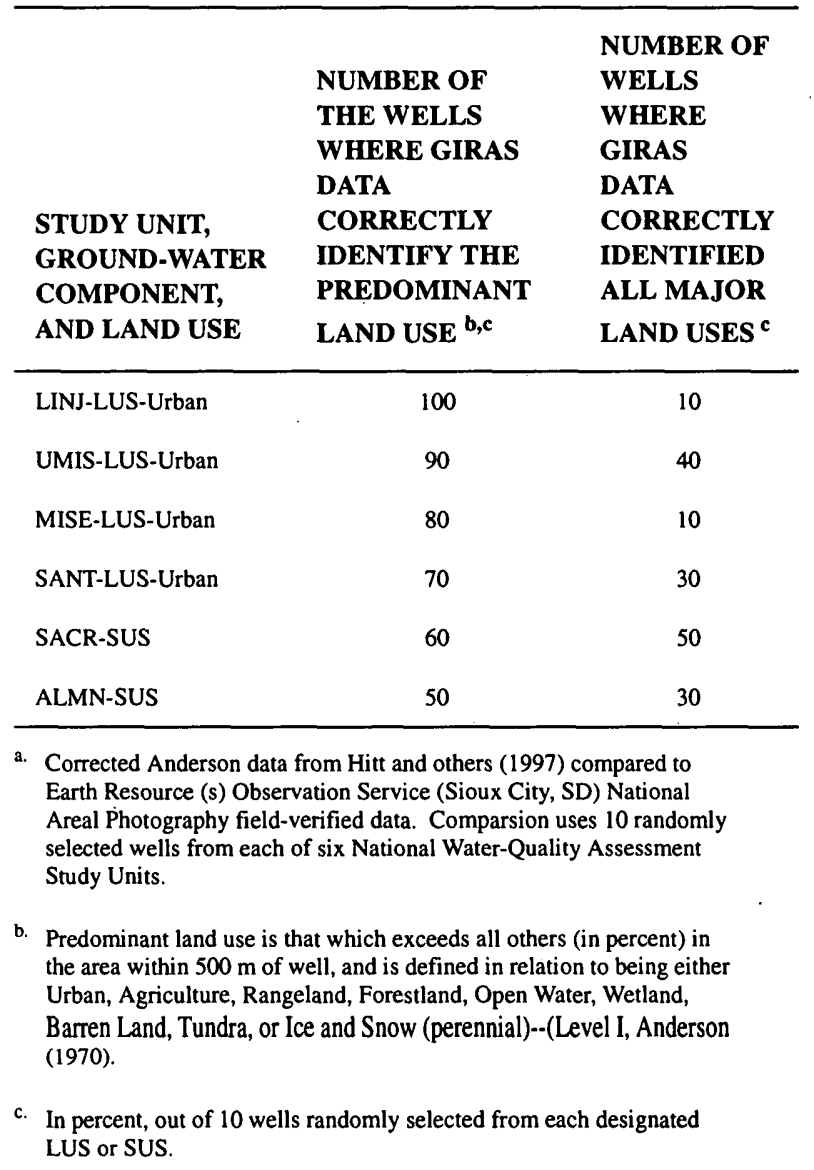

14. Level I implies land use is either Urban, Agriculture, Rangeland, Forestland, Open Water, Wetland, Barren Land, Tundra, or Perennial Ice and Snow. 
The second factor appeared to be differences in data age. Despite corrections for population density, GIRAS data are no more recent than about 1990. The NAP field-verified data reflect 1996-97 conditions at the time water-quality data were actually collected.

A third factor is related to the correction applied to the GIRAS data. The use of 1990 population density to correct 1970's land-use data appears to led to an overestimation of the extent of urban land use at the expense of other land uses for some wells.

The fourth and final factor relates to the location of the well. For some wells, it appeared that the $500-\mathrm{m}$ radius area obtained from the GIRAS data was not the same area as that used for the NAP field-verified data. These areal shifts in point of reference could be the result of error in the well location (latitude and longitude) data, or in the GIRAS coverage. The shift illustrates a common problem inherent in the use of digital landscape data extracted for a point or small area.

Results for the TI data (table 14) indicate that these data correctly indicated the predominant land use within $500 \mathrm{~m}$ of the well for 70 to 90 percent of the wells in a given LUS or SUS. The TI data also accurately identified the predominant land use about equally well for either an SUS or LUS. But comparisons between the landscapes generated by TI and NAP data for each of the 30 wells indicate the TI data overestimated the extent of forested, agricultural (pasture), and reclaimed (mined) lands at the expense of other land uses. Thus, the TI data were only accurate in the identification of all major land uses at no more than 60 percent of the wells for the SUS, and at no more than 20 percent of the wells in either LUS.

A review of landscape differences between the TI and NAP data sets for the 30 wells indicate that a combination of factors similar to those discussed for the GIRAS data also appear to also limit the accuracy of the TI data, but to a lesser degree. The TI data have a resolution that is approximately a few tenths of a hectare, which is better than the resolution of the GIRAS data, but still not as accurate as that of the NAP field-verified data. In addition, although the TI data are more recent (early 1990 's) than the GIRAS data, they are not as current as the NAP (1996-97) field-verified data.
Table 14. Comparison of thematic imagery 1990's land-use data to National Aerial Photography, field-verified (1996-1997) land-use data for the area within 500 meters of a well ${ }^{a}$

[TI, thematic imagery; LINJ, Long Island-New Jersey Coastal Drainages; SANT, Santee Rjver Basin and Coastal Drainages; and ALMN, Allegheny-Monongahela Basin; LUS, Land Use Study; SUS, Study (Sub)-Unit Survey]

\begin{tabular}{|c|c|c|}
\hline & $\begin{array}{l}\text { NUMBER OF } \\
\text { THE WELLS } \\
\text { WHERE TI }\end{array}$ & $\begin{array}{l}\text { NUMBER OF } \\
\text { WELLS } \\
\text { WHERE TI }\end{array}$ \\
\hline STUDY UNIT & DATA & DATA \\
\hline AND & CORRECTLY & CORRECTLY \\
\hline GROUND- & IDENTIFY THE & DENTIFIED \\
\hline WATER & PREDOMINANT & ALL MAJOR \\
\hline COMPONENT & LAND USE $^{b, c}$ & LAND USES \\
\hline LINJ-LUS-Urban & 70 & 20 \\
\hline SANT-LUS-Urban & 90 & 10 \\
\hline ALMN-SUS & 70 & 60 \\
\hline
\end{tabular}

a. Thematic imagery data (from Gail Thelin, USGS, Sacramento, Calif., written commun., 1997) compared to Earth Resource(s) Observation Service (Sioux City, S. Dak.) National Areal Photography fieldverified data. Comparison uses 10 randomly selected wells from each of three National Water-Quality Assessment Study Units.

b. Predominant land use is that which exceeds all others (in percent) in the area within $500 \mathrm{~m}$ of well, and is defined in relation to being Urban, Agriculture, Rangeland, Forestland, Open Water, Wetland, Barren Land, Tundra, or Ice and Snow (perennial)--[Level I, Anderson (1970)].

c. In percent, out of 10 wells randomly selected from each designated LUS or SUS.

The TI coverage also misidentified selected land uses--as natural forested areas instead of developed areas with trees, as agricultural (pasture) lands instead of non-agricultural grassed areas, and as mining instead of construction. It also was evident that possible errors associated with the welllocation (latitude and longitude) data caused problems at some wells similar to the problems described earlier for the GIRAS data.

The two comparative studies reveal that the available GIRAS and TI data are limited in their ability to accurately indicate the landscape within $500 \mathrm{~m}$ of an SUS or LUS well. Neither coverage can consistently provide as accurate a description of land use as the NAP field-verified data. This is a 
critical limitation for LUS wells, which require a detailed description of land use and cover to aid in the interpretation of water-quality data. At best, the GIRAS or TI data coverage potentially could be used for SUS wells, but the data would have to be obtained on the basis of accurate well-location data, and then be field verified. On the basis of the comparative-study results, it also appears that extensive field corrections probably would be needed for many wells. For these reasons, the current GIRAS and TI were considered to be inappropriate to characterize the landscape in the vicinity of LUS or SUS wells.

The comparative studies also highlight the attributes of a suitable data coverage. Namely, that it be (1) of high resolution (tens of meters), (2) scaled to provide a $500-\mathrm{m}$ circular area that can be accurately verified, scanned, and digitized (1:20,000 or better), (3) nearly concurrent with the time of water-quality data collection, (4) widely available, and (5) accurate enough in location to reflect the actual area within 500-m of a well. On the basis of these attributes, the NAP imagery is currently the best available.

\section{Recommendations of the National Synthesis Teams and Other Reviewers}

Reviewer recommendations, which are incorporated into the guidance described in the remainder of this report, are as follows:

(1) That the pilot-study recommendations be adopted (table 11);

(2) That the area within $500 \mathrm{~m}$ of a well and NAP imagery be used for landscape characterization ${ }^{15}$

(3) That landscape characterization is required for all LUS wells (complete all items of LULCFS);
(4) That landscape characterization is required for those SUS where the age (or other waterquality) data for most wells indicates the ground water withdrawn is relatively modern water (recharged within the last 50 years, see table 12), and, except for the land-use and cover definitions (Appendix B), will be done in the same manner as that for LUS; otherwise, only that part of the LULCFS that identifies the well and site, and provides additional information on the well, including the re-evaluation of the well for NAWQA use, are done for each SUS well (Appendix A, items 1 and 6).

\section{General Guidance on Landscape Data Collection, Documentation, and Compilation}

The NAWQA Study-Unit chief and groundwater specialist (or designee) along with the NAWQA Central Processing Group for landscape characterization ensure that the required data (Appendix A) are collected, documented, verified, and compiled (table 15). This implies the following:

(1) That landscapes are characterized for every LUS well; and, in the case of SUS, for every well whenever most SUS wells indicate that the water withdrawn (sampled) is relatively modern in age ${ }^{16}$

(2) That the landscape characterization done for each well preferably is completed in the same year (and, ideally, growing season,) during which water-quality samples are collected;

(3) That landscape data are collected and documented by the Study-Unit team in accordance with the guidance and data-quality requirements described in this report; and,

(4) That the Study-Unit team and the NAWQA Central Processing Group (CPG) cooperate to process the LULCFS, and compile data in the NAWQA National Database Archive.

\section{General Approach}

To obtain the required breadth and quality of landscape data in an efficient manner, it is recommended that landscape characterization be integrated with other ground-water activities to complete all data collection for an LUS (or SUS) in

\footnotetext{
${ }^{16}$ See table 12, previous section for determination of ground-water age. If the landscape characterization is not done for SUS wells, then only part (Appendix A, items 1 and 6 ) of the LULCFS is completed for every SUS well.
} 
Table 15. Work items, and parties responsible, for the completion of the Land-Use and Land-Cover Field Sheet for a well

[LULCFS, Land Use and Land-Cover Field Sheet (Appendix A); USGS, U.S. Geological Survey; m, meter; LUS, Land-Use Study; SUS, Study (Sub)-Unit Survey]

\begin{tabular}{|c|c|c|c|}
\hline $\begin{array}{l}\text { LULCFS } \\
\text { ITEM }^{\text {a }}\end{array}$ & $\begin{array}{l}\text { WORK ITEM } \\
\text { DESCRIPTION }\end{array}$ & STUDY-UNIT TEAM & CENTRAL PROCESSING GROUP \\
\hline 1 & $\begin{array}{l}\text { Identify well, site, contacts, and } \\
\text { field-personnel, and record } \\
\text { date. }^{b}\end{array}$ & Provide all data for item. & Check data correctly submitted. \\
\hline 2 & $\begin{array}{l}\text { Describe imagery and its quality } \\
\text { for area (s) characterized. }\end{array}$ & $\begin{array}{l}\text { Except for Part B of item, provide } \\
\text { all data, and a USGS 7.5-minute } \\
\text { quadrangle map with location of } \\
\text { well and area within } 500 \mathrm{~m} \text { of well. }\end{array}$ & $\begin{array}{l}\text { Check data (Parts A and C) correctly } \\
\text { submitted; use Quadrangle map to register } \\
\text { overlay, and document registration in Part } \\
\text { B. }\end{array}$ \\
\hline 3 & $\begin{array}{l}\text { Describe land use and cover, and } \\
\text { management practices. }{ }^{c}\end{array}$ & $\begin{array}{l}\text { Except for the percent cover of area } \\
\text { within } 500 \mathrm{~m} \text { of well, provide all } \\
\text { data for item. }\end{array}$ & $\begin{array}{l}\text { Check data correctly submitted; and } \\
\text { compute percent cover of each land use } \\
\text { within } 500 \mathrm{~m} \text { of well. }\end{array}$ \\
\hline 4 & Identify other local features. & Provide all data. & Check data correctly submitted. \\
\hline 5 & Describe soil characteristics. & Provide all data. & Check data correctly submitted. \\
\hline 6 & Describe and evaluate well. & Provide all data. & Check data correctly submitted. \\
\hline 7 & Additional comments. & As needed for above. & Check data correctly submitted. \\
\hline 8 & $\begin{array}{l}\text { Action items to resolve; and } \\
\text { identity of Central Processing } \\
\text { Group. }\end{array}$ & $\begin{array}{l}\text { As needed to respond to action } \\
\text { items. }\end{array}$ & $\begin{array}{l}\text { Process all data; identify and resolve } \\
\text { action items with Study-Unit team; check } \\
\text { own work, and compile data. }\end{array}$ \\
\hline
\end{tabular}

a. For each LUS, complete all items. For each SUS, complete all items for every well, if ground water withdrawn from most wells is modern in age; otherwise, only complete items 1 and 6 for each SUS well.

b. Contacts to access site (Appendix A, item 1 F) will not be recorded by Central Processing Group, nor put into National Water-Quality Assessment Program National Archive data base.

c. For LUS wells, use detailed land-use and cover definitions and codes; for SUS wells, if land-use characterization is required, use general land-use and cover definitions and codes (Appendix B).

a single (fiscal) year (table 16). The recommended approach does more than simply provide the required data in this time frame; it enables the use of data obtained from one completed activity to be used to better plan, execute, or otherwise make decisions that aid in the completion of a subsequent activity.

Under the recommended approach, the LULCFS is the primary archival document for landscape data and other (well-related) data that cannot be stored in GWSI. For each LUS or SUS well, all or at least part of the LULCFS (Appendix A) identifies the required data that must be collected. Completion of the LULCFS for an individual well requires the following (table 15):

(1) Identification of NAWQA ground-water components to which the well belongs (all wells); 


\section{Table 16. Recommended timing of activities for a ground-water component of the National Water-Quality Assessment (NAWQA) Program}

[LUS, Land-Use Study; SUS, Study (Sub)-Unit Survey; GWSI, Ground-Water Site Inventory; QWDATA, Quality of Water data base; NAP, National Aerial Photograph; CPG, Central Processing Group]

\begin{tabular}{|c|c|c|}
\hline TIME PERIOD & WORK ITEM DESCRIPTION & DATA OBTAINED FOR SUBSEQUENT ACTIVITY \\
\hline October --February & $\begin{array}{l}\text { Select or install all wells for LUS or SUS. } \\
\text { Collect site, well, and subsurface (GWSI) data; } \\
\text { compile site and well data in database. } \\
\text { If needed, order nonperishable sampling equipment } \\
\text { early; and perishable equipment later; but allow for } \\
\text { field testing in early March. }\end{array}$ & $\begin{array}{l}\text { Provides site, well, and subsurface data to establish GWSI } \\
\text { site records. } \\
\text { Provides initial water-level data to select sampling } \\
\text { equipment, estimate purging times for wells and } \\
\text { traveltimes to wells, and develop sampling schedule } \\
\text { (Koterba and others, 1995). Provides accurate latitude } \\
\text { and longitude to order best NAP for well. Provides site, } \\
\text { well, and subsurface data to aid in re-evaluation of well } \\
\text { for continued use, and interpretation } \\
\text { of water-quality data. }\end{array}$ \\
\hline March -- mid-April & $\begin{array}{l}\text { Prepare equipment for ground-water sampling and } \\
\text { test it early. } \\
\text { Establish sampling sites in water-quality database } \\
\text { (QWDATA records). }\end{array}$ & $\begin{array}{l}\text { Provides equipment-blank data to evaluate readiness to } \\
\text { sample. } \\
\text { Records are means of early access to water-quality } \\
\text { age-related data. }\end{array}$ \\
\hline Mid-April --mid-June & $\begin{array}{l}\text { Collect water-quality samples and field data. } \\
\text { Review age-related data from each SUS well as it } \\
\text { becomes available. }\end{array}$ & $\begin{array}{l}\text { Provides water-quality data on age of ground water } \\
\text { sampled, or on presence or absence of anthropogenic } \\
\text { compound to: } \\
\text { (a) assess whether or not SUS wells require landscape } \\
\text { classification; } \\
\text { (b) identify the lithologic materials to describe in } \\
\text { relation to each well; and } \\
\text { (c) aid in the re-evaluation of the well for continued } \\
\text { NAWQA use. }\end{array}$ \\
\hline Mid-June --mid-July & $\begin{array}{l}\text { Order NAP imagery for LUS (SUS) as soon as } \\
\text { possible for wells at which water-quality samples } \\
\text { were obtained. } \\
\text { Obtain soil maps and complete all LULCFS items } \\
(1,2 \text {, and 5) that do not require data from field, } \\
\text { prepare overlays, and make final preparations for } \\
\text { landscape classification. }\end{array}$ & $\begin{array}{l}\text { Provides imagery and other materials to expedite field } \\
\text { work, and completion of landscape characterization. } \\
\text { (Identifying and ordering NAP's take only a day; but } \\
\text { receiving NAPs can take up to five to six weeks). }\end{array}$ \\
\hline Mid-July -- August & $\begin{array}{l}\text { Conduct field trips to collect data and document } \\
\text { landscape for all wells. }\end{array}$ & $\begin{array}{l}\text { Provides landscape data for re-evaluation of well, and for } \\
\text { interpretation of water-quality data. }\end{array}$ \\
\hline September & $\begin{array}{l}\text { Re-evaluate well for continued use. Review } \\
\text { documentation to ensure all data are correct. } \\
\text { Submit landscape data for all wells in organized } \\
\text { manner to CPG to process and compile. Complete } \\
\text { (compile) lithologic description in GWSI database } \\
\text { for each well. }\end{array}$ & \\
\hline
\end{tabular}


(2) A qualitative and quantitative description of landscape characteristics in the vicinity of each well; derived on the basis of visual observations and selected sources of information; to identify land uses and covers, management practices, potential point sources, and soils (all LUS wells; and all SUS wells if most of latter reflect modern-age ground water);

(3) A description of selected well characteristics that currently (1998) cannot be stored in the GWSI data base, including a re-evaluation of the well for continued NAWQA use (all wells).

If landscape characterization at a well is required, the LULCFS is completed in accordance with NAWQA guidance contained in this section and the subsequent section of this report. This guidance mainly ensures that the quality and scope of the data collected are adequate for NAWQA Program objectives. It also indicates that the only difference in the landscape characterization among wells is that for LUS wells, the detailed land-use and cover categories are used (see Appendix B), whereas for SUS wells (that require classification), the general land-use and cover categories are used (see Appendix B).

The landscape characterization for each well should be completed in relation to at least two areas (table 15): one within $50 \mathrm{~m}$ of the well, and the other within $500 \mathrm{~m}$ of the well. The characterization of any other area (for example, one considered upgradient of the well) is in addition to the above, and is optional. Also, unless approved in advance as a comparative study by the National NAWQA Program, an optional area is characterized entirely (including use of CPG processing) at the expense of Study-Unit funds.

The area within $50 \mathrm{~m}$ of a well is characterized mainly to (a) assess whether or not the area closest to the well differs markedly from the landscape within $500 \mathrm{~m}$ of the well, and (b) to emphasize the identification of any potential point sources in proximity to the well. The land use and potential point sources within 50 meters of the well generally are identified solely on the basis of visual observations. A visual record of this area can be constructed on the field form provided (fig. 2). This form also allows estimation of the percent coverage of this area by each identified land use and cover (Appendix A; item 3, table 3), and identification of the type and location of any potential point source(s) within $50 \mathrm{~m}$ of the well (Appendix A; item 4, table 4, including their nearest occurrence to the well).

Characterization of the area within $500 \mathrm{~m}$ of the well describes the landscape that is most likely to be associated with the probable recharge area around the well. It is conducted on the basis of visual observations in conjunction with (1) a colorless, transparent (mylar) overlay pin-punched to, (2) a high-resolution, high-contrast black and white $\left(1: 20,000\right.$ scale or better) remote image (NAP) ${ }^{17}$ of the landscape that surrounds the well, and (3) the LULCFS (Appendix A, items 3 and 4). The imagery facilitates the identification and estimation of the extent of land uses, management practices, potential point sources of contamination, and other landscape features in the vicinity of a well. It also provides the CPG with a "landscape-at-time-of sample" image that can be electronically documented, and used to quantify current and future patterns in land use.

The purpose of the overlay is to field-verify, identify by code (and if necessary, correct), and ultimately document the physical boundaries and identity of each land use and cover within $500 \mathrm{~m}$ of the well. It also is recommended that the StudyUnit team mark this overlay to indicate (if possible) the probable direction of ground-water flow to the well. The overlay information, once transferred to the electronic image of the registered NAP, provides the time-of-sample image of landscape conditions. This also allows the CPG to calculate the relative extent of coverage (as a percentage) of the area within $500 \mathrm{~m}$ of the well by each identified land use and cover, which is then recorded on the LULCFS (Appendix B; item 3, table 3).

\footnotetext{
17. In general, National Aerial Photographs (NAPs) from the Earth Resource Organization Data Center, Sioux Falls, S. Dak. are to be used (see Specific Guidance section below). Use of imagery other than a NAP must be evaluated in relation to selected attributes (see Alternative Imagery, under Review by National Synthesis Team and Others, this report), and requires pre-approval by the CPG (see Specific Guidance section below).
} 
Characterization of the area within $500 \mathrm{~m}$ of the well also involves the use of field observations to identify management practices related to each identified land use and cover (Appendix A, items 3 $\mathrm{B}, \mathrm{C}, \mathrm{D}$, or $\mathrm{E})$. In addition, visual observations are used to complete identification of the type and closest location of potential point sources of contamination, which, if the area within $50 \mathrm{~m}$ of the well already has been characterized, focus on the area between $50 \mathrm{~m}$ and $500 \mathrm{~m}$ from the well (Appendix A; item 4, table 4).

In general, the only landscape feature within $500 \mathrm{~m}$ of the well not likely to be identified on the basis of visual observations are predominant soil characteristics (Appendix A, item 5). These are to be identified using county soil maps (approximately $1: 24,000$ scale). ${ }^{18}$

In addition to general landscape characteristics, the LULCFS (Appendix A, item 6) provides for additional documentation of well characteristics that cannot be easily stored in GWSI, and for a reevaluation of the well for continued NAWQA use by the Study-Unit ground-water specialist (or designee). In part (Appendix A, items $6 \mathrm{~A}$ and $\mathrm{B}$ ), data are required on sample-collection point and pumping characteristics. [These data are best obtained when the well is either selected or installed (Lapham and others, 1995).] In part (Appendix A, items $6 \mathrm{C}$ and $\mathrm{D}$ ), documentation is required of the review of ancillary (GWSI and LULCFS) data and water-quality data in relation to NAWQA design guidelines (re-evaluation of the well). The primary purpose of this re-evaluation is to identify whether or not the well is still suitable for continued NAWQA use. ${ }^{19}$

Landscape documents are shipped by the StudyUnit team to the NAWQA CPG. For an SUS whose wells do not require landscape characterization, only a photocopy of the completed LULCFS (items 1 and 6) for each SUS well is required by the CPG. For any LUS, and any SUS whose wells require landscape characterization, the original LULCFS and overlay for each well are photocopied. The original NAP, and photocopies

\footnotetext{
18. Soil maps should be those prepared by the U.S. Department of Agriculture, Natural Resources Conservation Service.

19. For example, to aid in the identification of wells for long-term monitoring (Walton Low, U.S. Geological Survey, NAWQA Coordinator, Low-Intensity Phase, Reston, Va., written commun., 1997).
}

of the overlay and LULCFS, are combined with a clean USGS 7.5-minute quadrangle (with the well and a scaled version of the area within $500 \mathrm{~m}$ of the well clearly marked) for each well, and this set of documents for all wells of the given LUS or SUS are sent under return receipt and heavily insured to the NAWQA CPG.

The CPG provides many services to the StudyUnit teams and NAWQA National Program (table 15). For each LUS or SUS that requires landscape characterization, the overlay-corrected area within $500 \mathrm{~m}$ of each well is digitized and registered. Using field-verified imagery, the percent cover for each identified land use is computed (to complete item 3, table 3, 500-meter buffer). The CPG also makes use of multiple quality-control checks to ensure computations are correct, and that each image is similarly and accurately registered to a single projection (Albers) and single reference datum (NAD83). Finally, the CPG re-verifies that all LULCFS items have been completed, and that the data for these items are submitted in the proper format.

Any problems are identified by the CPG as action items (Appendix A, item 8). If minor problems arise, the CPG contacts the Study-Unit team directly for corrections. If a problem severely affects data processing, however, the CPG returns the materials to the Study-Unit team for correction. Upon resolution of all action items, the CPG compiles the LULCFS data into the NAWQA National Archive data base, and returns all materials, including a digitized, registered, and field-corrected NAP image, and a completed LULCFS, to the Study-Unit team.

Overlays, completed LULCFS forms, NAP's, and, if used, the 50-m form (fig. 2), are all important documents. These documents form the basis from which all future changes in the landscape are determined. They need to be handled by the StudyUnit team and CPG accordingly, and are archived in Study-Unit files (Lapham and others, 1995; Documentation Section). 


\section{Resource Requirements}

For an SUS with wells that do not require the landscape classification, only part of the LULCFS should completed (items 1 and 6). Assuming that the required well data (items $6 \mathrm{~A}$ and $\mathrm{B}$ ) have been correctly collected during well selection or installation, less than 15 hours of personnel time in the office should be needed to complete the above work.

For LUS wells, and SUS wells that require landscape characterization, the pilot study indicated that between 100 to 300 hours were needed to complete the required data collection and documentation for 30 wells (table 9). The last PilotStudy team (Santee River Basin and Coastal Drainages Study Unit), however, benefitted from many of the recommendations eventually put forth by other Pilot-Study teams (table 11). They completed their work for an urban LUS in about 90 hours. In addition, because of changes in the manner in which NAP's are ordered, obtaining NAP's currently (1998) takes only a few hours instead of the 20 to 30 hours it took the Pilot Study teams to order NAPs.

If Study-Unit teams follow the current general and specific guidance described in this report, which includes pilot-study and review-team recommendations, it should take between 60 to 90 personnel hours to complete the landscape classification for 30 wells in an LUS, or, if necessary, an SUS. Less time generally is needed if (1) land use and cover associated with an LUS (or SUS) is not complex (for example, monocrop largescale agricultural and natural areas), and (2) field personnel do not require extended periods of (overnight) travel. Generally more time is required if (1) this is the first time a landscape classification is done, (2) work is in areas of complex land use and cover (for example, urban and mining areas), and

(3) extensive travel among sites is required.

Marked increases in the resources required also can occur if (1) no effort is made to review initial landscape characterization efforts after the first few wells are done to improve efficiency, (2) landscapes arè unnecessarily "overcharacterized", (3) many individuals are used to complete a given activity, (4) too much emphasis is placed on a final review after field work to correct and finalize overlays and
LULCF or (4) the CPG commonly finds problems that cannot be easily resolved (for example, dataquality requirements (table 14) are not met, numerous coding errors are found, field notes generally is illegible, or parts of the LULCFS or overlay have not been completed or have been incorrectly done).

Field work can be conducted by permanent USGS or temporary (Student-Intern) staff. In either case, it is recommended that the NAWQA ground-water specialist either attend landscape characterization activities at the first several sites, or review work conducted at these sites, to aid development of a consistent and efficient procedure for all sites. This could imply some revision of work for the first few sites. With this experience, however, planning the completion of field activities can subsequently be done on the basis of experience with Study-Unit conditions. The Study-Unit team also can assess whether the level of classification being used is insufficient, sufficient, or overly detailed, as well as evaluate recommendations made by the Pilot Study and review teams (see table 11, and the Recommendations by National Synthesis Teams and Others section). This is critical given the cost of field work.

The major costs associated with landscape characterization are for personnel (including their per diem for field work and vehicles). Equipment costs mainly consist of the cost for NAP's, which are lowest if the Study-Unit team requests the USGS discount at the time these are electronically ordered. For other recommended equipment, the only other significant cost could be for a range finder (accurate at distances of 50 to $500 \mathrm{~m}$ ).

\section{Specific Guidance on Selected Landscape Data}

To obtain landscape data in an accurate, efficient, and cost-effective manner, Study-Unit teams that collect and document these data should be familiar with specific guidance that describes how and when to complete the items on the LandUse and Land-Cover Field Sheet (Appendix A). This guidance assumes that characterization work is completed immediately after water-quality samples have been collected (table 16), and in relation to three major periods of activity--work conducted either before returning to the well sites, at each well site, or after returning to the well sites (table 17). 


\section{Table 17. Recommended sequence of activities after water-quality sampling to obtain landscape data for wells used by the National Water-Quality Assessment (NAWQA) Program}

[LULCFS, Land-Use and Land-Cover Field Sheet; CPG, Central Processing Group; in., inch; m, meter; cm, centimeter]

\begin{tabular}{|c|c|c|}
\hline $\begin{array}{l}\text { TIMING OF } \\
\text { ACTIVITY }\end{array}$ & $\begin{array}{l}\text { DESCRIPTION OF } \\
\text { ACTIVITY }\end{array}$ & $\begin{array}{l}\text { STANDARD PROCEDURES TO COMPLETE } \\
\text { REQUIRED ACTIVITY }^{\text {a }}\end{array}$ \\
\hline \multirow[t]{7}{*}{$\begin{array}{l}\text { PRE-FIELD } \\
\text { ACTIVITIES }\end{array}$} & $\begin{array}{l}\text { Order or otherwise } \\
\text { obtain remote image } \\
\text { for each well. }\end{array}$ & $\begin{array}{l}\text { Use high-resolution black and white National Aerial Photographs (NAP's) from } \\
\text { U.S. Geological Survey Earth Resources Organization (EROS) Data Center, } \\
\text { Sioux Falls, SD. Recommend NAP that is within } 5 \text { years of date of water-quality } \\
\text { sampling, and that is } 36 \text {-in. x 36-in. for complex land use (urban or mining); but no } \\
\text { smaller than 18-in. x 18-in. A 9-in. x 9-in. NAP is unsuitable. }\end{array}$ \\
\hline & $\begin{array}{l}\text { Order any other field } \\
\text { equipment. }\end{array}$ & $\begin{array}{l}\text { Recommended equipment: (1) maps (and a global positioning system if needed) to } \\
\text { relocate well. (2) U.S. Geological Survey 7.5-minute quadrangle that shows well location } \\
\text { and area within } 500 \mathrm{~m} \text { of well, (3) directional compass; (4) camera and film; (5) } \\
\text { range finder for distances of at least } 50 \text { to } 550 \mathrm{~m} \text {; (6) large clipboard and clips to } \\
\text { hold maps or overlay and NAP; and (7) pin punch, (8) colorless, transparent, plastic } \\
\text { (mylar) sheets, and (9) markers--high-contrast, photo-copiable, non-smear, fine- } \\
\text { point lead or ink that leaves clearly visible and continuous line on mylar sheet. }\end{array}$ \\
\hline & Identify well and site. & $\begin{array}{l}\text { LULCFS: item 1--A, B, C, D, and E. Complete in accordance with formats specified } \\
\text { by the NAWQA Data Integration and Software Group for the NAWQA National }\end{array}$ \\
\hline & & Archive data base Archive. ${ }^{\mathbf{b}}$ (Contacts for site access are not compiled in data base). \\
\hline & $\begin{array}{l}\text { Identify soil } \\
\text { characteristics. }\end{array}$ & $\begin{array}{l}\text { LULCFS: item } 5^{c} \text {. Use U.S. Department of Agriculture Natural Resources } \\
\text { Conservation Service County soil survey map }(1: 24,000) \text {; for LUS, use } \\
\text { predominant soil in area of targeted land use within } 500 \mathrm{~m} \text { of well; for SUS, use } \\
\text { predominant soil in area within } 500 \mathrm{~m} \text { of well. }\end{array}$ \\
\hline & $\begin{array}{l}\text { Verify and document } \\
\text { image suitability. }\end{array}$ & $\begin{array}{l}\text { LULCFS: item 2--A (and C d). For each well, check that NAP contains the well } \\
\text { location, and on the basis of scale, includes all of the area within } 500 \text { m of well; } \\
\text { otherwise return NAP for credit and/or obtain an additional NAP to provide } \\
\text { required coverage. Document characteristics of suitable NAP's (item 2). Record } \\
\text { ground-water component and well identifiers on edge of NAP with permanent } \\
\text { marker. Plot well location (fine small point) on suitable NAP. Place removable } \\
\text { adhesive note paper near well location so it can be easily located by CPG. }\end{array}$ \\
\hline & $\begin{array}{l}\text { Field-test landscape } \\
\text { characterization. }\end{array}$ & $\begin{array}{l}\text { Select two or three wells and test field procedures described below. Review results } \\
\text { with ground-water specialist (or designee), and revise planned activities accordingly } \\
\text { to improve work. }\end{array}$ \\
\hline \multirow[t]{4}{*}{$\begin{array}{l}\text { FIELD } \\
\text { ACTIVITIES }\end{array}$} & $\begin{array}{l}\text { Record date and } \\
\text { identify field } \\
\text { personnel. }\end{array}$ & $\begin{array}{l}\text { LULCFS: item 1--F. For date, use four-digit number for year (YYYY). Identity of } \\
\text { Study-Unit personnel required by CPG if questions arise during processing of data. }\end{array}$ \\
\hline & $\begin{array}{l}\text { Prepare and attach } \\
\text { overlay to NAP. }\end{array}$ & $\begin{array}{l}\text { Plot well location (as small point) and } 500 \mathrm{~m}^{+} \text {circle (as fine line) around this point on } \\
\text { mylar sheet. Radius of circle }(\mathrm{cm}) \text { should correspond to more than } 500 \mathrm{~m} \text {; and be } \\
\text { the larger of (a) the NAP-scaled length of }(500 \mathrm{~m}+\mathrm{x} \mathrm{m}\} \text {, where } \mathrm{x} \text { is the measured }\end{array}$ \\
\hline & & $\begin{array}{l}\text { error }(\mathrm{m}) \text { in well location data }{ }^{e}, \text { or }(\mathrm{b}) \text { an NAP-scaled length from a rangefinder } \\
\text { measurement taken at the well of an easily identifiable and permanent object } \\
\text { located about } 530 \mathrm{~m} \text { from the well. To attach mylar sheet to NAP, align well- } \\
\text { location points, and pin-punch documents outside of } 500 \text {-m circle (do not tape). } \\
\text { Trim off overlay sheet that extends beyond NAP. Keep overlay clean and neat, and } \\
\text { along with NAP, free of creases to avoid problems with electronic processing. }\end{array}$ \\
\hline & $\begin{array}{l}\text { Document overlay } \\
\text { orientation (and } \\
\text { possible direction of } \\
\text { ground-water flow). }\end{array}$ & $\begin{array}{l}\text { Use compass to determine (magnetic) North and mark this direction on the overlay } \\
(-->\mathrm{N}) \text {. Determine possible direction of ground-water flow within } 500 \mathrm{~m} \text { of well, } \\
\text { mark this on mylar sheet (---> PDGWF), and document how this direction was } \\
\text { determined (LULCFS item 7). }{ }^{\mathrm{f}}\end{array}$ \\
\hline
\end{tabular}


Table 17. Recommended sequence of activities to obtain landscape data for wells used by the National Water-Quality Assessment (NAWQA) Program--Continued

\begin{tabular}{|c|c|c|}
\hline $\begin{array}{l}\text { TIMING OF } \\
\text { ACTIVITY }\end{array}$ & $\begin{array}{l}\text { DESCRIPTION OF } \\
\text { ACTIVITY }\end{array}$ & $\begin{array}{l}\text { STANDARD PROCEDURES TO COMPLETE } \\
\text { REQUIRED ACTIVITY a }\end{array}$ \\
\hline \multirow[t]{3}{*}{$\begin{array}{l}\text { FIELD } \\
\text { ACTIVITIES-- } \\
\text { Continued }\end{array}$} & $\begin{array}{l}\text { Characterize well } \\
\text { conditions. }\end{array}$ & $\begin{array}{l}\text { LULCFS: item 6--A and B. Use camera to photograph sample-point location, } \\
\text { conditions at the well head, and measuring-point location for depth data. If } \\
\text { possible for water-supply wells, obtain copy of water-use record to document } \\
\text { recorded pumping characteristics. (Best if obtained at time well is selected or installed). }\end{array}$ \\
\hline & $\begin{array}{l}\text { Characterize } \\
\text { landscape } \\
\text { within } 50 \mathrm{~m} \text { of well. }\end{array}$ & $\begin{array}{l}\text { LULCFS: item 3, A ( } 50 \text {-m buffer), and item } 4 \text {, table } 4 \text { (A through } \mathrm{G} \text { as necessary, and } \\
\text { only within } 50 \mathrm{~m} \text { of well). Use range finder to locate } 50 \text {-m boundaries, and } \\
50 \text {-m form grids to estimate percent coverages, for each identified land use and cover. } \\
\text { Check that percentage estimates total } 100 \text {. Use camera to document the landscape } \\
\text { from the well head in the direction of each cardinal compass point. }\end{array}$ \\
\hline & $\begin{array}{l}\text { Characterize the } \\
\text { landscape within } \\
500 \mathrm{~m} \text { of the well. }\end{array}$ & $\begin{array}{l}\text { D97LULCFS: item 3--A (500-m buffer, except for percent coverages), B, C, D, and E; } \\
\text { and item 4, table } 4 \text { (A through G as necessary). Use NAP to guide drive-bys, and, } \\
\text { with rangefinder, to identify land uses and covers (by codes for either LUS or SUS } \\
\text {--Appendix B), and their boundaries in the circular area of mylar overlay. Upon } \\
\text { completion, lift overlay by edge to check entire circular area has been } \\
\text { characterized. Also list identified land ises and covers (in table 3). Because the } \\
\text { area within } 50 \mathrm{~m} \text { of well already has been done, identify potential point sources (in } \\
\text { table 4) between } 50 \text { and } 500 \mathrm{~m} \text { of well. For sources not already identified within } \\
50 \mathrm{~m} \text {, identify closest occurrence to well. Overlay work and writing must be legible } \\
\text { or it will affect data processing by CPG. }\end{array}$ \\
\hline \multirow[t]{6}{*}{$\begin{array}{l}\text { POST-FIELD } \\
\text { ACTIVITIES }\end{array}$} & $\begin{array}{l}\text { Re-evaluate well for } \\
\text { continued use. }\end{array}$ & $\begin{array}{l}\text { LULCFS: item 6--C and D. Ground-water specialist or designee reviews field and } \\
\text { file notes, ancillary and water-quality data, and NAWQA design criteria to } \\
\text { re-evaluate well for continued use. }\end{array}$ \\
\hline & $\begin{array}{l}\text { Prepare and ship } \\
\text { material } \\
\text { for processing. }\end{array}$ & $\begin{array}{l}\text { Photocopy original D97LULCFS and original mylar overlay. Combine these } \\
\text { photocopies with original NAP and original (clean) USGS QUAD map for each } \\
\text { well. Make sure well location and identity is clearly indicated on NAP and QUAD } \\
\text { with removable adhesive notes. Stack document sets for all wells in either LUS or SUS, } \\
\text { and, roll (not fold) for shipment. Ship documents heavily insured and with return receipt } \\
\text { to the CPG } \mathrm{g}\end{array}$ \\
\hline & Address action items. & $\begin{array}{l}\text { If contacted by the CPG, respond promptly to reduce processing delays or the } \\
\text { unnecessary return of unprocessed materials. }\end{array}$ \\
\hline & $\begin{array}{l}\text { Archive processed } \\
\text { materials. }\end{array}$ & $\begin{array}{l}\text { Upon completion of processing, CPG will return documents, and include a completed } \\
\text { LULCFS and instructions on how to retrieve electronic digitized and registered } \\
\text { images of the area within } 500 \mathrm{~m} \text { of each well. These documents are to be archived } \\
\text { in Study-Unit well files (Lapham and others, 1995; documentation). }\end{array}$ \\
\hline & $\begin{array}{l}\text { Update landscape } \\
\text { characterization. }\end{array}$ & $\begin{array}{l}\text { In general, landscape should be updated each time water-quality data are collected, if it } \\
\text { appears that there has been a noticeable change in the landscape that potentially could affect }\end{array}$ \\
\hline & & ground-water quality, or if SUS well is incorporated into an LUS ground-water component. ${ }^{h}$ \\
\hline
\end{tabular}

a. Use of alternative methods or materials require advanced approval by the NAWQA CPG, or in the case of the characterization of an area in addition to that within $500 \mathrm{~m}$ of well, by the National Program.

b. T.L. Miller, U.S. Geological Survey, May 1997. National Water-Quality Assessment Memorandum: National Data Aggregation Request.

c. Soil area of interest determined on the basis of well location (generally in relation to 1927 Navigational Reference Datum). For SUS a mylar disc that reflects the area within $500 \mathrm{~m}$ of well scaled to soil map. For LUS, area of land use of interest can be temporarily sketched on disc, and then oriented correctly to identify soils to be characterized.

d. If an optional area is characterized in addition to the area within $500 \mathrm{~m}$ of well, use a second D97LULCFS and second overlay with well point and the optional-area boundaries, in conjunction with the NAP to complete landscape verification of this area. Be sure to clearly identify these documents are for an optional area, and provide adequate documentation of this area (D97LULCFS complete item 2 C).

e. Determined at time well selected or installed--see General Site Data under Specific Guidance on Collection of Selected Types of Subsurface Data.

f. For example, assuming local ground-water-flow patterns are reflected in local topographic relief, one could use the U.S. Geological Survey 7.5-minute quadrangle with visual observations in field to assess the possible direction on ground-water flow in the area within $500 \mathrm{~m}$ of the well.

8. Ship to NAWQA Central Processing Group, C/O Craig Harvey, USGS, Fed.BIdg., Room 269, 400 S. Clinton St., lowa City, IA, 52240. (Internet: caharvey@usgs.gov).

h. Updates of material are sent to CPG for processing and compiling data in national archive. 
The guidance is presented in a manner that assumes landscape characterization is required. If this is not the case, then the wells must be from an SUS, and water-quality data must indicate that ground water withdrawn is not relatively modern in age (see previous section on General Guidance). In this situation, all that needs to be done on the LULCFS for each well is covered under just three of the described activities (table 17--Pre-Field Activities--Well Identification (Appendix A, item 1), and Well Characterization (Appendix A, item 6), and Post-Field Activities--Review, Shipment, and Processing of Documents). If the Study-Unit team has obtained the required data for well characterization on previous site trips (preferably at the time the well was selected or installed), then they should be able to complete all three of these activities on the basis of information already in well site files, and not need to return to the field.

The recommended order of the activities listed (table 17) is to improve efficiency, and is not necessarily the order in which the data obtained are described in the LULCFS. For example, preparations for landscape characterization include completion of some parts of the LULCFS before field work begins (table 17, Pre-Field Activities). This reduces the overall time required to complete landscape characterization, and also provides data from the completion of one activity that can be used to better plan, execute, or make decisions in relation to a subsequent activity than otherwise would have been possible (for more examples, see table 16). 


\section{References Cited}

Alley, W.M., 1993, General design considerations in: Alley, W.M. (ed.), Regional Ground-Water Quality, Chapter One, Van Nostrand Reinhold, New York, N.Y., p. 1-21.

Ator, S.W., and Denis, J.M., 1997, Relation of nitrogen and phosphorus in ground water to land use in four subunits of the Potomac River Basin: U. S. Geological Survey Water-Resources Investigations Report 96-4268, 26 p.

Ator, S.W., and Ferrari, M., 1997, Nitrate and selected pesticides in ground water of the Mid-Atlantic Region: U.S. Geological Survey Water-Resources Investigations Report 97-4139, 8 p.

Anderson, J.R., Hardy, E.E., Roach, J.T., and Witmer, R.E., 1976, A land use and land cover classification for use with remote sensor data: U.S. Geological Survey Professional Paper 964, $8 \mathrm{p}$.

Banks, W.S.L., and Koterba, M.T., 1992, Analysis of cropping practices and pesticide use from a regional data base and a field survey of the Delmarva Peninsula in Agricultural WaterQuality Priorities, A team approach to conserving natural resources. 17th Beltsville Symposium, May 5-8, 1992, U.S. Department of Agriculture, Beltsville, MD, p. 60.

Barringer, T., Dunn, D., Battaglin, W., and Vowinkel, E., 1990, Problems and methods involved in relating land use to ground-water quality: American Water Resources Association Water Resources Bulletin 26 (1), p. 1-9.

Cain, D., Helsel, D.R., and Ragone, S.E., 1989, Preliminary evaluations of regional ground-water quality in relation to land use: Ground Water 27 (2): p. 230-244:

Cowardin, L.M., Carter, V., Golet, F.C., and LaRoe, E.T., 1979, Classification of wetlands and deepwater habitats of the United States: U.S. Department of Interior Fish and Wildlife Service Office of Biological Services, Washington D.C., $121 \mathrm{p}$.

Cowdery, T.K., 1997, Shallow ground-water quality beneath cropland in the Red River of the North Basin, Minnesota and North Dakota, 1993-95: U.S. Geological Survey Water-Resources Investigations Report 97-4001, 52 p.
Ferrari, M.J., and Ator, S.W., 1995, Nitrate in ground water in the Great Valley Carbonate Subunit of the Potomac River Basin: U.S. Geological Survey, Water-Resources Investigations Report 95-4099, $6 \mathrm{p}$.

Gilliom, R.J., Alley, W.A., and Gurtz, M E., 1995, Design of the National Water-Quality Assessment Program: occurrence and distribution of waterquality conditions: U.S. Geological Survey Circular 1112, $33 \mathrm{p}$

Hardy, M.A., Leahy, P.P., and Alley, W.M., 1989,

- Well installation and documentation, and groundwater-sampling protocols for the pilot National Water-Quality Assessment Program: U.S. Geological Survey Open-File Report 89-396, 36 p.

Helsel, D.R., 1995, Design of relational water-quality assessment program in: Proceedings of the Biometric Section of the American Statistical Association, 1995, p. 60-67.

Hitt, K.J. 1994, Refining 1970's land-use data with 1990 population data to indicate new residential development: USGS Water-Resoures Investigations Report, 94-4250, 15 p.

Kolpin, D.W., 1997, Agricultural chemicals in ground water of the midwestern United States: Relations to land use: Journal of Environmental Quality 26 (4): p. 1025-1037.

Koterba, M.T., W.S.L. Banks, and Shedlock, R.J., 1993, Pesticides in shallow groundwater in the Delmarva Peninsula: Journal of Environmental Quality 22 (3): p. 500-518.

Koterba, M.T., Wilde, F.W., and Lapham, W.W., 1995, Ground-water data-collection protocols and procedures for the National Water-Quality Assessment Program: Collection and documentation of water quality samples and related data: U.S. Geological Survey Open-File Report 95-399, 113 p.

Lapham, W.W., Wilde, F.D., and Koterba, M.T., 1995, Ground-water data-collection protocols and procedures for the National Water-Quality Assessment Program: Selection, installation, and documentation of wells, and collection of related data: U.S. Geological Open-File Report 95-398, $69 \mathrm{p}$. 
1996. Guidelines and standard procedures for studies of ground-water quality: Selection and installation of wells, and supporting documentation. U.S. Geological Survey: WaterResources Investigations Report 96-4233, 110 p. Scott, J.C., 1990, Computerized random site-selection approaches for design of a ground-water-quality sampling network: U.S. Geological Survey Water-Resoures Investigations Report 90-4101, Oklahoma City, OK, 109 p.
Squillace, P.J., and Price, C V., 1996, Urban land-use study plan for the National Water-Quality Assessment Program: U.S. Geological Survey Open-File Report 96-217, 19 p. 


\section{Appendixes}




\section{APPENDIX A}

\section{NAWOA December 1997, Land-Use Land-Cover Field Sheet}

This document summarizes landscape information to be obtained from visual observations in the field combined with remote aerial or other imagery in the vicinity of a well. There are 8 "items" $(1,2,3, \ldots)$ to complete. Instructions to complete items are provided in U.S. Geological Survey Water-Resources Investigations Report 98-4107: "Ground-Water Data Collection Protocols and Procedures for the National Water-Quality Assessment Program: Collection, Documentation, and Compilation of Required Site, Well, Subsurface, and Landscape Data for Wells, by M.T. Koterba (1998).

If additional sheets are used to complete this form, they must contain the appropriate headings (LULCFS, SUID, Date, Site ID, Area Described, Item \#, continued). References to "additional guidance" refer to the above report. 


\section{LAND-USE LAND-COVER FIELD SHEET- GROUND-WATER COMPONENT OF NAWQA STUDIES (12/97)}

\section{Item 1. GENERAL WELL AND SITE IDENTIFICATION AND FIELD RECONNAISSANCE INFORMATION (SU Staff:)}

A. NAWQA Study-Unit (4-letter code) Well Station ID

Local ID

B. NAWQA Study-Unit Ground-Water Components to which well belongs (code all that apply, see additional guidance for codes)

Study-(Sub)-Unit Survey Land-Use Study

Flowpath Study

C. Well Type (check one): Selected by Study Unit __ Installed by Study Unit

D. Well Location, as measured (Except for second-order surveys, location should be by Precise Lightweight Global Receiver with National reference Datum of 1983, NAD83):

1. Latitude __ _ _ L Longitude (hrs, min, sec, tenth of sec); on basis of following (check one):

Global Postioning System, PLGR __ Surveyed USGS 1:24,000 (7.5') Quad Other, specify:

Estimated accuracy of location coordinates: Within (plus or minus) Coordinate datum (Check One) NAD83 NAD27 Other, specify meter.

E. Contacts for Site Access and Permission to Collect Samples (for Study-Unit File only). (If 1 and 2 below are similar, complete 1. , put "same as above" for Name in 2., and leave the remainder of 2. blank):

1. Site manager or other resident or responsible party:

Name:

Address (Street, Town, State, Zip code)

Telephone:

(daytime) (evenings)

2. Well owner:

Name:

Address (Street, Town, State, Zip code):

Telephone: (daytime) (evenings)

F. Date of Field Reconnaissance (MM/DD/YYYY)

1
Conducted by

Item 2. GENERAL LAND USE AND LAND COVER (LULC) CLASSIFICATION INFORMATION: If neither aerial photography (AP), nor satellite, or other, imagery (SI), is used, explain why in "Additional Comments" (Item 7). Otherwise, complete items 2.A, 2.B, and, if optional area is done, 2.C below.

A. (SU staff:) Describe the AP or SI used to characterize 500-m (or optional) area. Include source (e.g., NAP), date (month and year [MMMYYY]), scale (e.g., 1:12,000 ft) and, for SI only, resolution (pixel size in meters). If more than one AP or SI is needed for the well, attach an additional sheet with the proper heading and provide data similar to that below for the additional AP or SI.

AP Source

SI Source

Date

Date

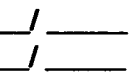

Scale (approx.)

Scale (approx.

Resolution

B. (Central Processing Group, CPG:) Identify at least three reference points (R\#) on each AP or SI for digitization and registration of transparent overlay (label as R1, R2, R3,...). Provide coordinates each (below). If more than one AP or SI is needed for the well, additional reference points are needed (at least 3 per AP or SI). If more than six reference points are needed, attach an additional sheet with the proper headings to provide additional reference-point data.

R 1. Location Latitude:

R 2. Location Latitude:

Longitude:

R 3. Location Latitude: Longitude: Longitude:

R 4. Location Latitude R 5. Location Latitude R 6. Location Latitude Longitude: Longitude:

C. (SU staff:) If optional area is being classified in addition to required area (s), describe this area and how it was determined:

Description of optional area:

Method of determination: 
Item 3. MAJOR LAND USES AND PRACTICES (SU staff, except for percent of area within 500-m or optional area:) Identify major land-use and cover categories in the vicinity of the well. (See instructions LULCFS, page 1, and the additional guidance for an example of a completed table).

\section{A. Table 3. Major land uses and practices identified in vicinity of the well.}

[Only those land-use and cover categories that occupy at least $5 \%$ of an area $(50-\mathrm{m}, 500-\mathrm{m}$, or optional) should be listed in table. Do not list any land-use and cover more than once, but place an $\boldsymbol{X}$ in the narrow unlabeled column before each "percent" column to indicate which area (s) have at least $5 \%$ of their area occupied by the listed category. If a land-use category occurs in an area, but occupies less than $5 \%$ of that area, it is included as part of the "General. miscellaneous" category for that area, and its code listed for that area below the table. Codes for irrigation column--I, Irrigated; NI, Not Irrigated; Codes for Drainage column--ND, no structural drainage enhancement; ES, enhanced drainage that promotes surface-water runoff (e.g., tile drains, lined or concrete ditches, storm sewers); EG, enhanced drainage that promotes local recharge to ground water (e.g. dewatering well, unlined infiltration, catchment, or runoff retention ponds); or ESG, enhanced drainage that promotes surface-water runoff and ground-water recharge (unlined ditches, and low capacity ponds, or catchments, with spillways. CPG computes percentages for shaded columns (percent of 500-m or optional area).

\begin{tabular}{|c|c|c|c|c|c|c|}
\hline $\begin{array}{l}\text { Land Uses and Covers: } \\
\text { Name and (code name) }\end{array}$ & $\begin{array}{l}\text { Percent of } \\
\text { area within } \\
50-\mathrm{m} \text { radius } \\
\text { of well }\end{array}$ & $\begin{array}{c}\text { Percent of } \\
\text { area within } \\
500-m \text { radius } \\
\text { of well }\end{array}$ & $\begin{array}{l}\text { Percent of } \\
\text { optional area } \\
\text { near well }\end{array}$ & $\begin{array}{c}\text { Irrigation } \\
\text { (I or NI) }\end{array}$ & $\begin{array}{c}\text { Drainage } \\
\text { (ND, ES, } \\
\text { EG, or } \\
\text { ESG) }\end{array}$ & $\begin{array}{c}\text { Source (s) } \\
\text { of Data } \\
\text { and } \\
\text { Comments }\end{array}$ \\
\hline & & & & & & \\
\hline & & & & & & \\
\hline & & & & & & \\
\hline . & & & & & & \\
\hline & & & & & & \\
\hline & & & & & & \\
\hline & & & & & & \\
\hline & & & & & & \\
\hline & & & & & & \\
\hline & & & & & & \\
\hline & & & & & & \\
\hline & & & & & & \\
\hline & & & & & & \\
\hline & & & & & & \\
\hline & & & & & & \\
\hline & & & & & & \\
\hline & & & & & & \\
\hline & & & & & & \\
\hline & & & & & & \\
\hline $\begin{array}{l}\text { General, miscellaneous } \\
\text { (gen.mis); see below }\end{array}$ & & & & & & \\
\hline
\end{tabular}

For each area in which gen.mis is used, list land-use and cover codes that are included in gen.mis:

For 50-m area:

For 500-m area:

For optional area: 
Item 3. continued...

B. Characterize selected management practices generally used in cultivated area (s) within 500-m of the well (Utilize recorded field observations to complete items below):

1. Extent of irrigation - Check the item that best describes the cultivated area (s) within $500 \mathrm{~m}$ of the well. Nonirrigated Partly Irrigated Irrigated Supplemental irrigation in dry years only

2. Method of irrigation on cultivated land- Check those that are used in the irrigated area (s) within $500 \mathrm{~m}$ of the well; but place an $\boldsymbol{X}$, instead of a check, by the most extensively used method.

Circle Spray __ Handline Spray _ _ Flood _ _ Furrow __ Drip _ _ Other _ _ specify:

3. Source of irrigation water - Check those that are used in the irrigated area(s) within $500 \mathrm{~m}$ of the well; but place an $\boldsymbol{X}$, instead of a check, by the most extensively used source.

Ground water (wells) _ Springs _ Surface water _ Sewage effluent _ (Treatment: Primary _ Secondary _ Tertiary _ ) Other __, specify

4. Extent of enhanced drainage - Check the item that best describes drainage in the cultivated area (s) within $500 \mathrm{~m}$ of the well. (Natural--no obvious structural improvements; Localized--structural improvements (e.g., ditches) generally are limited to roadside edges of cultivated land; Extensive--Ditches, or tile drains and ditches, or wells are utilized within cultivated areas or throughout region to systematically aid drainage.)

Natural drainage __ Localized Enhancement Extensive Enhancement Supplemental, wet years only

5. Method of Drainage Enhancement - Check those that are used in the cultivated area (s) within $500 \mathrm{~m}$ of the well; but place an $\boldsymbol{X}$, instead of a check, by the most extensively used method.

Ditches

Drain Tiles and Ditches

Wells

Other , specify

6. Fertilizers, Pesticides, Lime, and Soil Amendments

Types - check those that are used in the cultivated area (s) within $500 \mathrm{~m}$ of the well; but place an $\boldsymbol{X}$, instead of a check, by those most extensively used (If not available or apparent, check NA).
NA Commercial Compost Green Manures type Other specify

Methods of Application - check those that are used in the cultivated area (s) within $500 \mathrm{~m}$ of the well; but place an $\boldsymbol{X}$, instead of a check, by those most extensively used (If not available or apparent, check NA).

NA Mechanical Spreading, Spraying, or Broadcasting Combination Other, specify

C. Characterize selected conditions generally found in residential area (s) within 500-m of the well (Use recorded field observations to complete items below):

1. Turf or grassed areas- Check the item in each category that best describes the residential area (s) within $500 \mathrm{~m}$ of well. Irrigation (check one): Most appear irrigated (watered) Most appear nonirrigated

Weeds (check one): Most appear weed free Most appear with weeds and (or) natural grasses

2. Lot Size, in general, of turf or grassed residential areas. Check all categories that apply to the area within $500 \mathrm{~m}$ of well, but place an $\boldsymbol{X}$, instead of a check, by the size range that predominates.

None Small $(<1 / 4$ acre) Medium (1/4-1 acre) Large ( $>1$ acre)

3. Prevalence of Trash in residential area (s) - Check the item that best describes the area within $500 \mathrm{~m}$ of well. Well maintained (little trash) Poorly maintained (abundant trash, including abandoned cars, appliances, etc.)

4. Check the type(s) of storm-water runoff controls found in residential areas, but place an $X$ by the predominant type:

Ground-water recharge: Natural drainages __ Unlined ditches Unlined retention ponds Dry well

Surface-water flow: Impermeable (e.g. cement) storm drains Lined detention ponds

5. Previous use of residential area (s) - Check all categories that apply to the area within $500 \mathrm{~m}$ of well, but place an $X$, instead of a check, by that which previously predominated.

Forest, unused Forest, managed Unforested, unused Cropland Pasture

Other specify: Unknown 
Item 3. continued ...

D. Characterize selected conditions generally found in commercial area (s) within 500-m of the well (Use recorded field observations to complete items below):

1. Turf or grassed areas-Check the item in each category that best describes these in commercial area (s) within $500 \mathrm{~m}$ of well. Irrigation (check one): Most appear irrigated (watered) Most appear nonirrigated

Weeds (check one): Most appear weed free Most appear with weeds and (or) natural grasses

2. Prevalence of Trash in commercial area (s) - Check the item that best describes the area within $500 \mathrm{~m}$ of well. Well maintained (little trash) Poorly maintained (abundant trash, including abandoned cars, appliances, etc.)

3. Check the type (s) of storm-water runoff controls found in residential areas, but place an $\boldsymbol{X}$ by the predominant type:

Ground-water recharge: Natural drainages __ Unlined ditches Unlined retention ponds Dry well Surface-water flow: Impermeable (e.g. cement) storm drains Lined detention ponds

4. Previous use of commercial area (s) - Check all categories that apply to the area within $500 \mathrm{~m}$ of well, but place an $\boldsymbol{X}$, instead of a check, by that which previously predominated.

Forest, unused Residential Forest, managed Other , specify:

Unforested, unused Unknown Cropland Pasture

E. Characterize selected mining practices or activities generally found within 500-m of well (Use recorded field observations or other information to complete items below):

1. General Type of Mining, check that which is most applicable:

A. Surface, Open pit or Quarry __ Strip (Cut) __ Placer ___

B. Subterranean, Shaft __ High-Low Wall __ Column and Gallery

2. Specify current status of mine, in relation to Surface Mining Control and Reclamation Act of 1977 (or State or Local Laws), and, if possible, number of years mine has been in this condition (If number of years unknown, use 'NA', not available):

A. Current status (check only one): Operational Abandon Reclaimed or Visibly Under Reclamation

B. Number of years in this state

3. General Purpose of Mining, check all that apply, but place an " $x$ " by the primary purpose for mining:

A. Metal ores: Iron _ Ferro-alloy (e.g. Chromium, Vanadium, Tellurium, ...) _ Copper _ Lead or Zinc _ Gold or Silver _ Mercury _ Radioactive (e.g., Urnanium, Radium, ...) _ Other Metallic Ores _ , specify

B. Nonmetallic: Fossil Fuels: Coal (bituminous or lignite) _ Coal (anthracite) _ Oil (crude) _ Oil (shale) _ Gas (natural) _ Other: Stone: Dimensional, Granite _ Marble _ Limestone _ Other _, specify

Stone: Broken or crushed, Granite _ Marble _ Limestone _ Other _, specify

Sand or Gravel __, specify type

Clay, ceramic, or refractory minerals __, specify type

Chemical or fertilizer minerals: Potash, soda, or borate _, specify type

Phosphate _, specify type

Other _, specify

4. Indicate major geologic units mined and possibly exposed (include overburden and tailings, as well as resource unit, and also specify source of information:

Major Geologic Series exposed:

Source (s) of information (for maps include scale and date) 
Item 4. LOCAL LAND-USE FEATURES IN VICINITY OF THE WELL. (SU staff:) Describe observed local features within 500-m of the well (in Table 4, below). Also enter the information requested in the table for that feature. Features can be added (under table sections on Mining or Other). If added, provide a unique three capital-letter code for that feature. Selected table 4 features also can be identified on the transparent overlay (see LULCFS, page 1). If this is done, use the unique, three-capital-letter code to identify the features on the overlay.

Table 4. Occurrence of selected local features in the vicinity of the well (NA, not applicable).

\begin{tabular}{|c|c|c|c|}
\hline Feature & $\begin{array}{l}\text { Number of } \\
\text { occurrences } \\
\text { within } 500 \mathrm{~m} \\
\text { of well }\end{array}$ & $\begin{array}{l}\text { Approximate } \\
\text { distance (m) } \\
\text { from well to } \\
\text { the nearest } \\
\text { occurrence }\end{array}$ & $\begin{array}{l}\text { Source (s) of Data, Comments } \\
\text { (For features that occur. and for which a percent } \\
\text { cover for } 500-\mathrm{m} \text { area was estimated, reference the } \\
\text { Item Table }(3,4,5 \text {, and } 6) \text { where this feature and } \\
\text { percentage estimate are recorded.) }\end{array}$ \\
\hline \multicolumn{4}{|l|}{ GENERAL FEATURES--various groupings $(A, B, C$, and $D)$} \\
\hline \multicolumn{4}{|l|}{$\begin{array}{l}\text { A. RIGHT OF WAYS--railroad, utility, water port, airport, and } \\
\text { roads--Identify closest occurrence within } 500-m \text { of well }\end{array}$} \\
\hline Railroad (RXR) & NA & & \\
\hline Utilities--Gas, oil, electric lines or pipes (UTL) & NA & & \\
\hline Water(sea)port (WSP) & NA & & \\
\hline Airport (AIR), also complete items below for airport & NA & & \\
\hline \multicolumn{4}{|l|}{ Military base (MB) } \\
\hline Roadway (RWY) & NA & & \\
\hline \multicolumn{4}{|l|}{ B. WASTE DISPOSAL MANAGEMENT FACILITIES } \\
\hline \multicolumn{4}{|l|}{$\begin{array}{l}\text { Landfill, Waste type: Domestic _(LFD), } \\
\text { Industrial___(LFI), or Mixed___(LFM) }\end{array}$} \\
\hline \multicolumn{4}{|l|}{ Residential-commercial Septic field (RSF) } \\
\hline \multicolumn{4}{|l|}{$\begin{array}{l}\text { Waste disposal pond, Waste type: Urban __ (DPU), } \\
\text { or Ind__ (DPI) }\end{array}$} \\
\hline \multicolumn{4}{|l|}{ Injection well, waste Urban __ (IWU), or Ind __ (IWI) } \\
\hline \multicolumn{4}{|l|}{ C. HYDROLOGIC AND RELATED FEATURES } \\
\hline \multicolumn{4}{|l|}{ Open-Water, bay or estuary (BOE) } \\
\hline \multicolumn{4}{|l|}{ Open-water, lake, natural _ (LN) or artificial _ (LA) } \\
\hline \multicolumn{4}{|l|}{ Open-Water, reservoir, lined__ (RL) or unlined__(RU) } \\
\hline $\begin{array}{l}\text { Open-Water Stream, river, or creek--Perennial___ } \\
\text { (STP) or Ephemeral __ (STE) }\end{array}$ & NA & & \\
\hline \multicolumn{4}{|l|}{ Salt flat or playa, Dry_(SD) or Wet__ (SW) } \\
\hline \multicolumn{4}{|l|}{$\begin{array}{l}\text { Spring, Geothermal }\left[>25^{\circ} \mathrm{C}\right] \_ \text {(SG) or } \\
\text { Nongeothermal _ }(\mathrm{SNG})\end{array}$} \\
\hline \multicolumn{4}{|l|}{ Sinkhole (SH) } \\
\hline \multicolumn{4}{|l|}{ D. OTHER WELL TYPES } \\
\hline \multicolumn{4}{|l|}{ Major withdrawal well (Use: ___ } \\
\hline \multicolumn{4}{|l|}{ Oil well (OW) } \\
\hline \multicolumn{4}{|l|}{ Artificial recharge well (ARW) } \\
\hline Windmill, indicator of old or abandoned wells (WIW) & & & \\
\hline
\end{tabular}




\begin{tabular}{|c|c|c|c|}
\hline Feature & $\begin{array}{l}\text { Number of } \\
\text { occurrences } \\
\text { within } 500 \mathrm{~m} \\
\text { of well }\end{array}$ & $\begin{array}{l}\text { Approximate } \\
\text { distance }(\mathrm{m}) \\
\text { from well to } \\
\text { the nearest } \\
\text { occurrence }\end{array}$ & $\begin{array}{l}\text { Source (s) of Data, Comments } \\
\text { (For features that occur. and for which a percent } \\
\text { cover for } 500-m \text { area was estimated, reference the } \\
\text { Item Table }(3,4,5 \text {, and } 6) \text { where this feature and } \\
\text { percentage estimate are recorded.) }\end{array}$ \\
\hline \multicolumn{4}{|c|}{$\begin{array}{l}\text { SPECIFIC FEATURES TO URBAN (E), AGRICULTURAL (F) } \\
\text { and MINING (G) }\end{array}$} \\
\hline \multicolumn{4}{|l|}{ E. URBAN FEATURES } \\
\hline Urban Chemical plant or storage facility (UCP) & & & Chemical (s) used and (or) stored: \\
\hline Underground storage tanks (UST) & & & Chemical (s) stored, if known: \\
\hline Site of known chemical spill (KCS) & NA & & Specify chemical (s), if known, Spill Date (YYYY): \\
\hline Industrial plants (INP) & & & Type (s): \\
\hline Large smoke stacks (LSS) & & & Type (s) of plant (s): \\
\hline \multicolumn{4}{|l|}{ Pipeline [Use: ___ $]$ (PIP) } \\
\hline \multicolumn{4}{|l|}{ Dry cleaner (DCL) } \\
\hline \multicolumn{4}{|l|}{ Gas station (GAS) } \\
\hline \multicolumn{4}{|l|}{ Automotive Repair Shops (ARS) } \\
\hline \multicolumn{4}{|l|}{ F. AGRICULTURAL FEATURES } \\
\hline \multicolumn{4}{|l|}{ Grain storage bin or elevator (GBE) } \\
\hline \multicolumn{4}{|l|}{ Agrichemical storage--fertilizers, pesticides,... (ACS). } \\
\hline \multicolumn{4}{|l|}{$\begin{array}{l}\text { Ag-fuel tanks, home-heating (AFH), or gasoline or } \\
\text { (AGD), indicate which }\end{array}$} \\
\hline \multicolumn{4}{|l|}{ Irrigation-return-flow pond or lagoon (RFP) } \\
\hline \multicolumn{4}{|c|}{$\begin{array}{l}\text { Manure storage, covered and contained (MCC) or } \\
\text { uncovered and not contained (MUC) [Indicate which, } \\
\text { and specify type of manure: }\end{array}$} \\
\hline \multicolumn{4}{|l|}{ Rural-residence septic fields (RSF) } \\
\hline \multicolumn{4}{|c|}{$\begin{array}{l}\text { G. MINING FEATURES. Specify in each case, and if identified } \\
\text { on overlay, provide unique, three-capital-letter code. }\end{array}$} \\
\hline & & & \\
\hline & & & \\
\hline & & & \\
\hline & & & \\
\hline & & & \\
\hline & & & \\
\hline & & & \\
\hline & & & \\
\hline
\end{tabular}




\begin{tabular}{|c|c|c|c|}
\hline Feature & $\begin{array}{l}\text { Number of } \\
\text { occurrences } \\
\text { within } 500 \mathrm{~m} \\
\text { of well }\end{array}$ & $\begin{array}{l}\text { Approximate } \\
\text { distance }(\mathrm{m}) \\
\text { from well to } \\
\text { the nearest } \\
\text { occurrence }\end{array}$ & $\begin{array}{l}\text { Source (s) of Data, Comments } \\
\text { (For features that occur. and for which a percent } \\
\text { cover for } 500-m \text { area was estimated, reference the } \\
\text { ltem Table }(3,4,5 \text {, and } 6) \text { where this feature and } \\
\text { percentage estimate are recorded.) }\end{array}$ \\
\hline \multicolumn{4}{|c|}{$\begin{array}{l}\text { OTHER, Specify in each case, and if identified on overlay, } \\
\text { provide unique, three-capital-letter code.for each }\end{array}$} \\
\hline & & & \\
\hline & & & \\
\hline & & & \\
\hline & & & \\
\hline & & & \\
\hline & & & \\
\hline & & & \\
\hline & & & \\
\hline & & & \\
\hline & & & \\
\hline & & & \\
\hline & & & \\
\hline
\end{tabular}

Item 5. SOIL CHARACTERISTICS (SU staff:)

Describe soils within $\mathbf{5 0 0 ~} \mathrm{m}$ of well. (See additional guidance for developed areas such as urban or industrial, including mining)

Soil name and map symbol, derived from Natural Resources Conservation Service (formerly Soil Conservation Service) county soil survey maps (e.g., Tama silt loam, 2-5\% slopes; 120B):

General soil type (e.g., silty loam, sandy clay loam, etc.):

General drainage characteristics ( $A$, for very well drained; $B$, moderately well drained; $C$, poorly drained; and $D$, very poorly drained):

Percent organic carbon, by weight (if available, usually a range of values): to

Does it appear, or is there other evidence, that development greatly altered soils ( $\mathrm{Y}$, yes; $\mathrm{N}, \mathrm{no}$; or $\mathrm{U}$, unknown):

Item 6. WELL CHARACTERISTICS (SU staff:)

A. Sample-Point Characteristics (required for all selected, production or water-supply wells, used for water-quality sample collection)

Sampling tap description and location in system (describe here if photograph not taken, and location not on site map):

If holding or pressure tank located upstream from sampling point, indicate type (holding or pressure and size of tank (gallons):

Other notable well features, if any (e.g., pitless adapter, frost pit, missing or leaky cap, well house, chemicals stored near well, etc): 
Item 6. continued...

B. Pumping Characteristics during normal use (if data available):

Approximate frequency (check that which generally applies):

Daily __, Monthly__, Seasonally__, Intermittent ; Annually

Approximate flowrate (gpm): Range Mean

Approximate duration (hrs): Range Mean

C. NAWQA Design-Criteria Evaluation (SU staff:) Listed below (Table 6) are the NAWQA design criteria to guide the selection or installation of a well that is used for water-quality data collection. Describe well in relation to these criteria in table and in terms of questions that follow this table.

Table 6. Evaluation of well in relation to the NAWQA design criteria for the ground-water components for which well is used. [Some criteria differ among NAWQA ground-water components. In relation to a given component (SUS, Study-Unit Survey; LUS, LandUse Study; FPS, Flowpath Study), each criterion is either required ( $)$, recommended (R), or not applicable (NA)). Given the groundwater design component (s) to which this well belongs (see Item 1.B), put an $\boldsymbol{X}$ under either Yes or No to indicate whether or not each required or recommended design criterion for that well has been met, and give source of information used to determine this.]

\begin{tabular}{|c|c|c|c|c|c|c|}
\hline \multirow[t]{2}{*}{ NAWQA well-selection or installation criterion } & \multicolumn{3}{|c|}{$\begin{array}{l}\text { Criterion } \\
\text { applicability for } \\
\text { NAWQA design } \\
\text { components }\end{array}$} & \multicolumn{2}{|c|}{$\begin{array}{l}\text { Is criterion } \\
\text { met for } \\
\text { components } \\
\text { to which this } \\
\text { well } \\
\text { belongs? }\end{array}$} & \multirow[t]{2}{*}{ Source of information } \\
\hline & sus & LUS & FPS & Yes & & \\
\hline 1. Well screened in subunit targeted for water-quality sampling & $\sqrt{ }$ & $\sqrt{ }$ & $\sqrt{ }$ & & & \\
\hline $\begin{array}{l}\text { 2. Well screened in an unconfined formation (NA for some SUS } \\
\text { wells) }\end{array}$ & NA & $\sqrt{ }$ & $\sqrt{ }$ & & & \\
\hline $\begin{array}{l}\text { 3. Well in ground-water recharge area (applicable for LUS other } \\
\text { than mining; NA for some SUS and FPS wells) }\end{array}$ & NA & $\sqrt{ }$ & NA & & & \\
\hline $\begin{array}{l}\text { 4. Well located in, or immediately downgradient from, land-use of } \\
\text { interest }\end{array}$ & NA & $\sqrt{ }$ & $\sqrt{ }$ & & & \\
\hline $\begin{array}{l}\text { 5. Land use within } 500 \mathrm{~m} \text { of well generally stable (for at least } 5 \text { years } \\
\text { before sampling) }\end{array}$ & $R$ & $\sqrt{ }$ & $\sqrt{ }$ & & & \\
\hline 6. Selected well not initially installed to detect contamination & $\sqrt{ }$ & $\sqrt{ }$ & $\sqrt{ }$ & & & \\
\hline $\begin{array}{l}\text { 7. Well located away from roads or highways (except for transporta- } \\
\text { tion-related LUS) }\end{array}$ & $\sqrt{ }$ & $\sqrt{ }$ & $\sqrt{ }$ & & & \\
\hline 8. Drilled (rather than dug, bored, or driven) well & $\sqrt{ }$ & $\sqrt{ }$ & $\sqrt{ }$ & & & \\
\hline $\begin{array}{l}\text { 9. Low-capacity well (observation, monitoring or domestic supply; } \\
\text { rather than irrigation, industrial or public supply) }\end{array}$ & 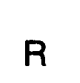 & $\sqrt{ }$ & $\sqrt{ }$ & & & . \\
\hline 10. Well properly sealed at land surface & $\sqrt{ }$ & $\sqrt{ }$ & $\sqrt{ }$ & & & . \\
\hline 11. Well cased to top of open interval & R & $\sqrt{ }$ & $\sqrt{ }$ & & & \\
\hline $\begin{array}{l}\text { 12. Top of screen located at least } 5 \mathrm{ft} \text { below lowest position of water } \\
\text { table during year }\end{array}$ & $\sqrt{ }$ & $\sqrt{ }$ & $\sqrt{ }$ & & & \\
\hline 13. Well screen no more than $10 \mathrm{ft}$ long & R & $\sqrt{ }$ & $\sqrt{ }$ & & & \\
\hline 14. No glued PVC casing joints used in construction & $\sqrt{ }$ & $\sqrt{ }$ & $\sqrt{ }$ & & & \\
\hline $\begin{array}{l}\text { 15. Sampling point upstream from holding or pressure tanks, and } \\
\text { water-treatment systems }\end{array}$ & $\sqrt{ }$ & $\sqrt{ }$ & $\sqrt{ }$ & & & \\
\hline
\end{tabular}


Item 6. continued...

On the basis of table above, check if all, or list them by table number if selected, design criteria considered by the SU staff in the selection or installation of this well: All , or

If criteria in addition to those above were a factor in the selection or installation of this well, please describe these criteria:

List by number any criteria that were relevant (recommended or required), but were not met, and explain why the well was selected or installed in spite of this. Criteria not met Explanation:

D. Other comments--discoveries made that could affect continued use of well for NAWQA studies. Could include analysis of data, such as water-quality data that indicate well doesn't reflect intended land use; or on pumping rate, such as well has low yield; or that repeated well-depth measurements indicate poor development, siltation, or well-screen collapse; or that well has been damaged, or permission to resample has been denied; or that well has been abandoned and the reason it was abandoned.

Item 7. ADDITIONAL COMMENTS (SU staff:) Describe any major modifications of the guidance to complete this form (for example, why an AP or SI was not used); explain missing data, and if that data eventually will be provided (for example, on an entire item, such as soils); or provide information on any site condition (s), feature (s) or process (es), possibly not covered, which the SU staff want to especially note because of their possible effects on ground-water quality. 
Item 8. LULCFS AND AP OR SI OVERLAY PROCESSING AND DATA BASE ENTRY (CPG):

Overlay processing and form completion by Date 1 Checked by Date

Data-base entry completed by:

Checked by

Date ___ I I I

Comments on quality of overlay and other LULCFS information provided for processing:

$\prime \prime$
$-\prime$
$\prime \prime$




\section{Appendix B}

\section{National Water-Quality-Assessment Program Land-Use and Land-Cover Definitions and Codes}

Land-use and land-cover definitions and their use

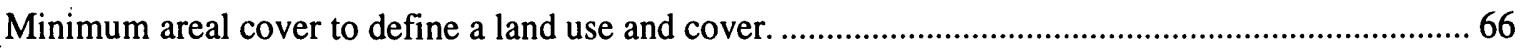

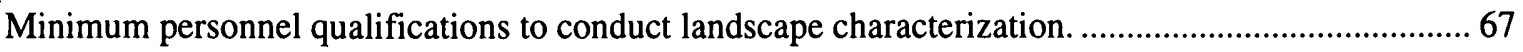

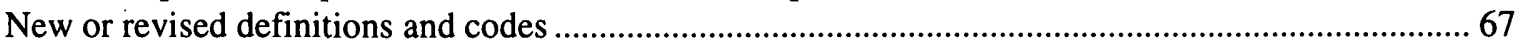

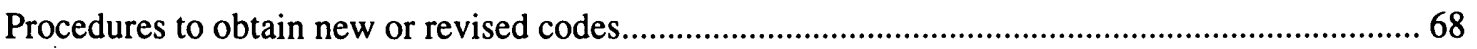

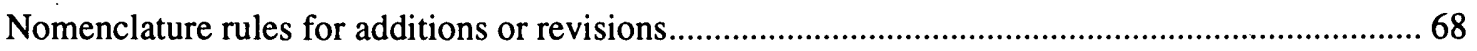

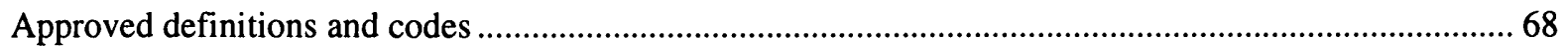

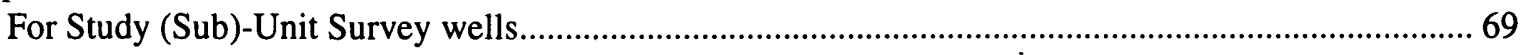

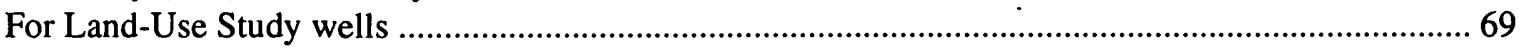

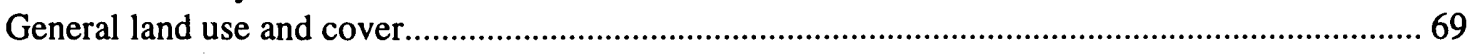

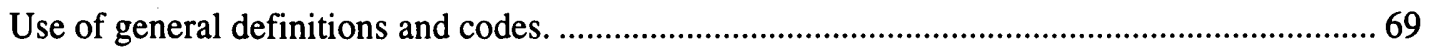

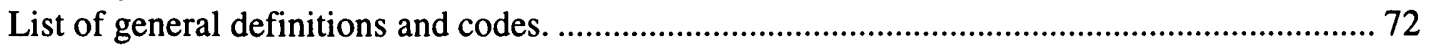

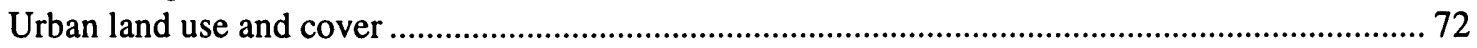

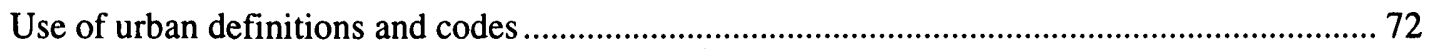

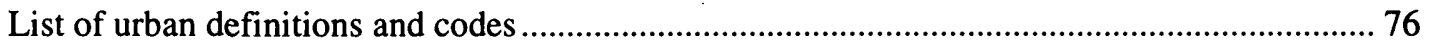

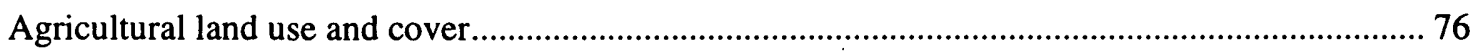

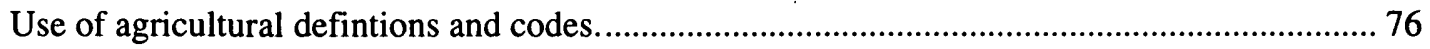

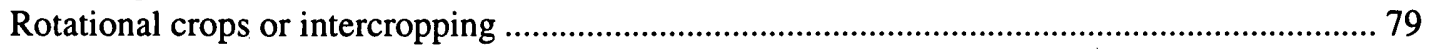

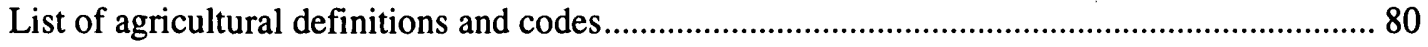

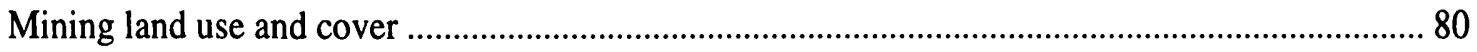

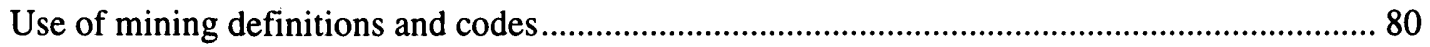

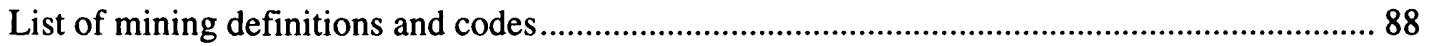




\section{Land-Use and Land-Cover Definitions and Their Use}

Landscape characterization for the National Water-Quality Assessment Program requires the identification of general and specific types of land use and cover. The general definitions of land use and cover (table B1) are similar to the broad categories defined by Anderson and others (1976, p. 8). Several Anderson categories were redefined or subdivided, however, to create categories that better relate to NAWQA Program assessment objectives, which in part target specific types of land use such as agriculture, urban, or mining. Agricultural land-use and cover identification for the NAWQA Program is based on modifications of the Crop Statistics Data base of the U.S. Departments of Commerce and Agriculture. Urban land use and cover identification utilizes a modified set of definitions from the Industrial Codes data base of the State of Washington, University of Washington, Seattle, Wash.

Wetlands are identified on the basis of definitions provided by Cowardin and others (1979).

\section{Minimum Areal Cover to Define a Land Use and Cover}

Use of the recommended imagery (a highresolution, high-contrast, black and white National Aerial Photograph, or NAP) implies a landscape resolution of approximately 100 square meters. This amounts to less than about one percent of the area within $500 \mathrm{~m}$ of a well. Resolving landscapes to this level of resolution is not necessary to obtain landscape data that can be related to ground-water quality (see table 8 this report). The accuracy with which one can electronically digitize small delineated landscape areas also renders meaningless detailed characterization that includes many small unique classifications. For these reasons, a land-use and cover for the NAWQA Program is defined as an area that occupies at least 5 percent of the area within $500 \mathrm{~m}$ of a well.

The 5-percent rule is applied at the time overlay and imagery (preferably NAP) are processed by the NAWQA Central Processing Group (CPG). This will exclude the digitization of point, line, and very small areas of relatively unique landscape features in relation to their surroundings.
Table B1. Comparison of National WaterQuality Assessment Program and Anderson and Others (1976) Land-Use Categories

\begin{tabular}{|c|c|}
\hline $\begin{array}{l}\text { National Water-Quality } \\
\text { Assessment Program } \\
\text { Categories }\end{array}$ & $\begin{array}{l}\text { Anderson and others } \\
\text { Categories }\end{array}$ \\
\hline Urban (I) & Urban or Built-up land (1) \\
\hline Agriculture (II) & Agricultural land (2) \\
\hline Rangeland (III) & Rangeland (3) \\
\hline Forestland (IV) & Forestland (4) \\
\hline Water (V) & $\begin{array}{l}\text { Water (5) and Perennial Ice and } \\
\text { snow (9) }\end{array}$ \\
\hline Wetland (VI) & Wetland (6) \\
\hline Barren land (VII) & Barren land (7) \\
\hline Tundra (VIII) & Tundra (8) \\
\hline Mining (IX) & $\begin{array}{l}\text { Subcategory under barren land (7), } \\
\text { Level II,--Only strip mines, } \\
\text { quarries, and gravel pits ( } 760) .\end{array}$ \\
\hline
\end{tabular}

If the excluded landscape feature does in fact represent a potential source of ground-water contamination it can be dealt with in one of two ways. If the landscape feature in question generally is an isolated occurrence, the Study-Unit team can identify it as a potential point source as defined by NAWQA (see Appendix A, item 4, this report). An examples of such a feature would be a single small gas station or residential home in a rural area within $500 \mathrm{~m}$ of the well that was dominated by crops. If the feature does in fact occupy a measurable percentage (for example from 1 to 4 percent) of the area within $500 \mathrm{~m}$ of the well, the Study-Unit team can identify it if need be as a potential point source of contamination, delineate it on the overlay, and identify it under an appropriate miscellaneous category (see Appendix A, item 3, table 3 , this report, and subsequent coding sections of this appendix). Finally, if the feature occupies a number of small areas throughout the area within $500 \mathrm{~m}$ of well, then it should be identified and delineated because it's aggregate area could exceed 
Table B2. Minimal areal size requirements to identify a land use and cover within 500 meters of a well that requires landscape characterization for a National Water-Quality Assessment Study (Sub)-Unit Survey or Land-Use Study

[in/mi, inch per mile; $\mathrm{ft} / \mathrm{ft}$, foot per foot; $\mathrm{cm}$; centimeter]

\begin{tabular}{|c|c|c|c|c|c|}
\hline \multicolumn{2}{|c|}{ Scale of imagery ${ }^{a}$} & \multicolumn{2}{|c|}{$\begin{array}{l}\text { Diameter of scaled circle } \\
\text { with } 500-\mathrm{m} \text { radius }\end{array}$} & \multicolumn{2}{|c|}{$\begin{array}{l}\text { Side dimension of square with } \\
\text { area that equals } 5 \text { percent }{ }^{b}\end{array}$} \\
\hline (in/mi) & $(\mathrm{ft} / \mathrm{ft})$ & (in) & (cm) & (in) & $(\mathbf{c m})$ \\
\hline 10 & 1: 6,336 & 6.2 & 15.8 & 1.2 & 3.1 \\
\hline 8 & 1: 7,920 & 5.0 & 12.6 & 1.0 & 2.5 \\
\hline 6 & $1: 10,560$ & 3.7 & 9.5 & .74 & 1.9 \\
\hline 4 & $1: 15,480$ & 2.5 & 6.3 & .49 & 1.3 \\
\hline 2 & $1: 21,120$ & 1.9 & 4.7 & .37 & .9 \\
\hline
\end{tabular}

a. From key given on imagery.

b. Side-length dimension of a square whose area is 5 percent of that of a circle with a $500-\mathrm{m}$ radius for the given scale.

5 percent. To aid in this assessment, dimensions of a square that would occupy 5 percent of a scaled circular area with the equivalent of a 500-m radius are provided (table B2).

\section{Minimum Personnel Qualifications to Conduct Landscape Characterization}

Landscape characterization requires some expertise in the identification of different types of vegetative cover. In agricultural areas, one should be able to identify different crop types, pasture lands, and livestock, as well as cultivation, irrigation, or management practices. It also tends to be best if this can be done during the growing season, when plants in many cases are readily recognizable. Because of their frequent occurrence, the ability to classify wetlands can be important. Wetlands should be classified in accordance with Cowardin and others (1979). In other areas, it could be important to be able to recognize different types of mining and reclamation operations. In most cases, it will be the surficial expression of different aspects of the mining (for example, tailing piles, resource piles, tailing ponds, and processing ponds), or the reclaimed mining feature that requires identification. For the purposes of NAWQA Program assessments, it is important that both the reclaimed land use and the historical (mined) land use be simultaneously identified.

\section{New or Revised Definitions And Codes}

New definitions and codes could occasionally be added to current approved codes. Previous definitions and codes could be modified. A periodic review of the last modification dates (see Documentation and Modification section below) ensures the most up-to-date definitions and codes are used. This will avoid data-processing delays by the CPG, which could be passed on to the StudyUnit team that fails to make a reasonable effort to use updated codes. A new land-use and cover 
definition must be unique and remain so, which is why directions are provided on how to obtain a unique code from the CPG.

\section{Procedures to Obtain New or Revised Codes}

Not all types of land use and cover are included in this appendix. New codes could be required simply because a given crop can be managed in different ways. For example, grasses can be grown for sod, seed or grain, hay or silage, or as pasture or green manure. Different uses commonly imply differences in irrigation, fertilization and pest control. Therefore, if a land use is encountered that (1) is of importance to the Study-Unit team, and (2) differs significantly in either vegetative type, cover, or use from the definitions and codes in this appendix, the Study-Unit team can develop a new definition and code, and ask for quick approval from the CPG to use this code.

To expedite code approval, definitions and codes are developed in accordance with the rules below, and submitted electronically as soon as possible to the CPG. Although an unapproved code can be used in the field without such approval, Study-Unit teams should not submit data for processing with unapproved codes. It will delay processing, or worse yet, produce significant datamanagement problems for the CPG and the National NAWQA Program.

Each approved code will be added to the appropriate SUS or LUS section of definitions and codes by the CPG. In addition, it will be posted (see "Documentation and Modification" section), and Study-Unit teams will be notified of the addition.

\section{Nomenclature Rules For Additions Or Revisions}

1. Use alpha codes to uniquely define each land use and cover. Alpha-code errors are easy to identify and correct as data are revised or processed.

2. Except for selected definitions and codes (that relate to areas with reclaimed mined lands), use a 6-letter alpha code (xxx.yyy) that consists of a 3-letter category name code, followed by a period, and then another 3-letter name or cover code.

3. Follow coding conventions used for major landuse and cover (sub) categories (see "LUS Definitions and Codes" section for examples).
4. Check that the code name is unique for all LULCFS code listings. To verify the code is unique, check the listings for SUS or LUS Definitions and Codes. (For LUS Definitions and Codes, see Alphabetical Code Listing). Any new or revised code must be unique in relation to all other NAWQA codes.

5. Submit the definition and code for approval by CPG as soon as possible. They will review the code, verify it is unique, and ensure that the same land use and cover does not end up with two different unique codes submitted by two different Study Units.

Example: About a decade ago, jojoba (a herbaceous plant, whose fiber can be used as forage, and seeds for oil) was touted as a "New Age" crop for the Southwest. Such a crop could be considered under Agriculture, Cropland (Category IV), and have a possible 3letter prefix "joj" for jojoba. Because it can appear as a row crop the cover code of interest could be "rwc." Upon approval, this crop could be listed under Agriculture, Category IV, as "jojoba (joj.rwc), seed, oil, or fiber". The "Documentation and Modification" section would cite its inclusion and the latest modification date for agriculture (above) would be changed accordingly.

\section{Approved Definitions and Codes}

The NAWQA definitions of land use and cover are used to characterize the landscape for all wells in a LUS or all wells in selected SUS. ${ }^{20}$ Each NAWQA land use and cover, whether it is general or specific in scope, is identified by a unique alpha code. These codes are used on the transparent overlays to define land use and cover with $50 \mathrm{~m}$, within $500 \mathrm{~m}$, and, if done, within an additional optional area of a well. The identified land use and cover and its code also appear on the LULCFS [(Appendix A, item 3, table 3 (this report)]. For consistency within and among Study Units, and for regional and national synthesis, all Study-Unit teams should use only the approved NAWQA definitions and codes described in this appendix.

20. SUS for which most wells indicate ground water withdrawn is relatively modern in age (see main text) 


\section{For Study (Sub)-Unit Survey Wells}

The approved definitions of land use and cover differ for SUS and LUS wells. For SUS wells, which are not selected or installed in relation to a specific land use, the land-use and cover definitions and codes are broad in scope (table B3). (To identify management practices related to irrigation or drainage in the vicinity of an SUS well, see "Use of General Definitions and Codes" under the General Codes section for LUS wells below).

\section{For Land-Use Study Wells}

For LUS wells, which generally are installed to identify the possible effects of a selected land use and cover on ground-water quality, the approved land-use and cover descriptions and codes provide detailed and specific descriptions of land use. Currently (1998), these definitions and codes include all the general categories covered under the approved definitions and codes for SUS well, but also target current or planned landscapes of national interest to the NAWQA Program--urban (residential and commercial), agricultural, and mining (in the four subsequent sections to this Appendix--General, Urban, Agricultural, and Mining).

To use LUS definitions and codes, begin landscape characterization with the land use targeted for study. Currently (1998) land uses targeted by the NAWQA Program include urban, agricultural, and, in limited areas, mining. After the targeted land use and cover has been identified and described, then other land uses and covers in the area that is being characterized are identified and described.

\section{General Land Use and Cover}

Although land use in the vicinity of LUS well should reflect that which is targeted for study, it is possible that other land uses beside the targeted land use could occur within the area that requires landscape characterization. For this reason, landuse and cover definitions and codes for LUS wells have been developed that include land uses and covers that are not necessarily targeted for study. These should not be used, however, until after a description of the targeted land use has been completed.
Use of General Definitions and Codes

To ensure complete and consistent characterization of general land use and cover within either $50 \mathrm{~m}, 500 \mathrm{~m}$, or, if added, an optional area of the well, proceed as follows:

(1) Read through this entire section at least once, including the remaining steps below, the example classifications, and the definitions of general land use and cover.

(2) For each land area to be classified, identify the appropriate land use and cover as follows:

(a) Select the appropriate general category and, if possible, within this category, the appropriate subcategory (see section on General Definition and Code List below).

(b) Note the selected (sub) category Name, and corresponding Code. The latter consists of two parts; a three-letter prefix of the form "gen" for "General," followed by a period, and then a threeletter code that uniquely identifies the (sub) category.

(c) Use this Code on the original grid $(50 \mathrm{~m})$ or overlay (within $500 \mathrm{~m}$ or optional area) to identify this and all other areas within the area being classified where this particular land use and cover appears. If applicable, add either an $I$ (irrigated) or $N I$ (not irrigated) to the end of the code on the grid or overlay. If applicable, add either an $N D$ (no enhanced drainage), $E S$ (enhanced drainage to surface flow), $\boldsymbol{E} \boldsymbol{G}$ (enhanced drainage to ground-water recharge), or $\boldsymbol{E S \boldsymbol { G }}$ (enhanced drainage to surface flow and ground-water recharge). (See Appendix A, item 3, table 3. Listed as "A3" in table of contents. See "Note" under "Appendix A" in the table of contents for clarification and examples.)

(d) Repeat step (2) through step (3) above for each different land use and cover until the entire area within either the $50-\mathrm{m}, 500-\mathrm{m}$ or optional area has been classified. 
Table B3. Land use and cover definitions and codes for Study (Sub)-Unit Survey (SUS) wells

\begin{tabular}{|c|c|c|c|}
\hline CATEGORY & SUBCATEGORY & CODE & EXAMPLES \\
\hline \multirow[t]{7}{*}{ URBAN $^{\text {a }}$} & Residential & urb.res & See Land-Use Study (LUS) definitions and codes: Urban, residential. \\
\hline & Commercial & urb.com & See LUS definitions and codes: Urban, commercial. \\
\hline & Mixed & urb.mrc & $\begin{array}{l}\text { Combine residential and commercial, if one or other is less than } 5 \text { percent of area being } \\
\text { characterized. }\end{array}$ \\
\hline & Other built-up land & urb.otr & $\begin{array}{l}\text { See LUS definitions and codes: Urban, other structurally developed land other than } \\
\text { commercial, residential, or under construction. }\end{array}$ \\
\hline & Forest or grassland & urb.gfl & $\begin{array}{l}\text { See LUS definitions and codes: Urban, for developed land without major structures--such as } \\
\text { managed parks and open recreational fields. }\end{array}$ \\
\hline & Construction & urb.con & For disturbed land that occurs in any of the above. (Different from Barren Land, see below.). \\
\hline & Miscellaneous & urb.mis & Include any urban area above that occupies less than 5 percent of the area being characterized. \\
\hline \multirow[t]{5}{*}{ AGRICULTURE $^{\mathrm{a}}$} & Cropland & agr.crp & See LUS definitions and codes: Agriculture, croplands. \\
\hline & Livestock & agr.lst & See LUS definitions and codes: Agriculture, livestock, open pasture to contained feedlot. \\
\hline & Orchard or nursery & agr.orn & See LUS definitions and codes: Agriculture, orchards and nurseries. \\
\hline & Infrastructure & agr.inf & See LUS definitions and codes: Agriculture--farm residence and related buildings. \\
\hline & Miscellaneous & agr.mis & Include agricultural area above that occupies less than 5 percent of area being characterized. \\
\hline \multirow[t]{4}{*}{ MINING $^{b}$} & Active & $\min . \operatorname{act} .-\mathbf{x x x}$ & $\begin{array}{l}\text { Nine-letter code; where xxx is either oil or gas (ogs), coal (col), hard-rock mineral }(\mathrm{hrm}) \text {, or } \\
\text { other resource (otr). }\end{array}$ \\
\hline & Reclaimed & $\begin{array}{l}\min . \operatorname{mrc} .- \\
\mathbf{x x x} . \mathbf{x x x}\end{array}$ & Twelve-letter code, where $\mathrm{xxx} . \mathrm{xxx}$ is the reclaimed land use defined from this table. \\
\hline & Abandon & $\begin{array}{l}\min . a b n .- \\
\mathbf{x x x} . \mathbf{x x x}\end{array}$ & $\begin{array}{l}\text { Twelve-letter code, where } x \times x . x \times x \text { likely is either brn.land or other undeveloped land use in } \\
\text { this table. }\end{array}$ \\
\hline & Miscellaneous & min.mis & Include any mined area above that occupies less than 5 percent of the area being characterized. \\
\hline BARREN $^{c}$ & None & gen.brl & $\begin{array}{l}\text { See LUS definitions and codes: General, Barren land (For example, beach or desert-dune, or } \\
\text { rock areas, but not construction). }\end{array}$ \\
\hline \multirow[t]{3}{*}{ FOREST $^{c}$} & Deciduous & gen.fdx & $\begin{array}{l}\text { See LUS definitions and codes: General, Forest, deciduous; } x=m \text {, intense silviculture, or } \\
x=n \text {, otherwise. }\end{array}$ \\
\hline & Coniferous & gen.fcx & $\begin{array}{l}\text { See LUS definitions and codes: General, Forest, coniferous; } x=m \text {, intense silviculture, or } \\
x=n \text {, otherwise. }\end{array}$ \\
\hline & Mixed & gen.fmx & $\begin{array}{l}\text { See LUS definitions and codes General, Forest, mixed; } x=m \text {, intense silviculture, and } \\
x=n \text {, otherwise. }\end{array}$ \\
\hline RANGELAND $^{c}$ & None & gen.rng & See LUS definitions and codes, General, Rangeland. \\
\hline WETLAND $^{c}$ & None & gen.wet & See LUS definitions and codes: General, Wetlands (Distinct from forest land). \\
\hline TUNDRA $^{c}$ & None & gen.tun & See LUS definitions and codes: General, Tundra. \\
\hline WATER ${ }^{c}$ & None & gen.wtr & $\begin{array}{l}\text { See LUS definitions and codes General: Open water or perennial snow and ice. Not sewage } \\
\text { waste or effluent, nor runoff-retention or diversion, nor irrigation return flow retention or } \\
\text { treatment ponds. }\end{array}$ \\
\hline GENERAL & Miscellaneous & gen.mis & $\begin{array}{l}\text { Include any subcategory above that occupies less than } 5 \text { percent of the area being characterized. } \\
\text { List each included subcategory in relation to the area being characterized (bottom of table } 3 \\
\text { item } 3 \text { of the Land-Use Land Cover Field Sheet). }\end{array}$ \\
\hline
\end{tabular}

a. Currently targeted by NAWQA National Program with LUS.

b. Currently targeted by NAWQA National Program with LUS in selected Study-Unit areas.

c. These as general (gen.) land uses not targeted by NAWQA National Program, but possibly by Study-Unit team because of local interests. 
(3) Apply the 5-percent coverage rule--Although it is best if landscape characterization can be completed in the field, it sometimes is necessary to revise the $50-\mathrm{m}$ grid or 500-m or optional-area overlay (in the office) after field work has been completed. Most revisions by the Study-Unit team only should involve conversions of an originally identified land use and cover that ultimately occupies less than 5 percent of the area being characterized. For example, during the field classification, any land use and cover, regardless of its areal extent, can be coded on the original 50-m grid, or 500-m (or optional-area) overlay. During the revision, to remain uniquely defined, the total area of any identified land-use and cover must equal or exceed 5 percent of the area that is being classified--for example, within $50 \mathrm{~m}$ or within $500 \mathrm{~m}$ of the well. If this is not the case, then the area in question should be redefined, if possible, as part of a mixed or miscellaneous category under a given type of land use and cover (see examples below or under revision discussions in "Urban, Agricultural, or Mining" sections). If this cannot be done, then the landscape area in question is treated as an anomalous or isolated occurrence as follows:

(a) Redefine the area as general, miscellaneous with the code (gen.mis) as follows:

List the original code for the area in question as a general miscellaneous item at the bottom of table 3 , item 3 of the LULCFS (Appendix A, and in relation to the area being characterized 50-m, 500-m, or optional); Relabel the area in question on the $50-\mathrm{m}$ grid or 500-m (or optional overlay) as gen.mis; Erase the original land use and cover and code listed for the area in question from either the 50-m, 500-m, or optional area column in table 3 , item 3 of LULCFS (Appendix A); and place an " $x$ " in the appropriate narrow column that corresponds to the area being characterized, which is across from the category "generalmiscellaneous", listed as the last land-use and cover type at the bottom of table 3 ; and

(b) Treat this area as a potential point source by noting its occurrence, and, if it is the closest occurrence of this type of potential point source, its distance from the well, in table 4 , item 4 of LULCFS
(Appendix A).

Examples: "Fuzzy" boundaries are transitional land use areas. For example, rangeland grassland can grade into rangeland trees and shrubs. In most cases, if the areas in question are both relatively small, an appropriate classification would be to define this area as a mixture of the two (see "List of General Definitions and Codes" section below). This retains the rangeland nature of the classification, and is preferable to the possibility that if not combined, the two areas must be redefined as general miscellaneous.

Another example of fuzzy boundaries involves tidal areas. In these areas, the high-tide mark should be used as the boundary between beach (generally barren) and other coastal land uses. Finally, in some cases, such as wetlands, it is important to recognize the wetland condition, rather than create an erroneous mixed subcategory. For example, palustrine wetlands in areas that border developed lands mistakenly could be coded as a combination of forest and grasslands.

Example: Assume about one third of the area within $500 \mathrm{~m}$ of a well already has been classified as some type of agriculture land, and another third of this area as some type of urban land. What remains is a stream-fed marshy area that contains open water, less than 6-ft deep and 20 acres in area at the lowest elevation.

Grasses surround this water and eventually give way to forest land that abuts the agricultural and urban areas. Except for the area of open water, this undeveloped area easily could be classified as a wetland, palustrine (gen.wpl). The openwater area can be classified as "open water" (gen.wat). During revision, the CPG finds that the open water occupies less than 5 percent of the area within $500 \mathrm{~m}$ of the well. The open water area is incorporated into the palustrine wetland area. The code and boundary for the open water does not appear on the digitized coverage, but the comments section across from the palustrine wetland listing in table 3 item 3 of Appendix A indicates by a code listing (gen.wat) that the wetland contains an area of open water.

Example: Assume in the example noted above that the palustrine wetland area, including the open water, occupied less than 5 percent of the area within $500 \mathrm{~m}$ of the well. The wetland and water areas would be recoded as part of "gen.mis" on the revised overlay, "general, 
miscellaneous (gen.mis)" would be " $x$ ' $d$ " in the narrow column for the 500-m area in table 3 , item 3 of Appendix A, and the codes "gen.wat" and "gen.wpl" would be listed as part of "general, miscellaneous" for the 500-m area classification at the bottom of table 3 , item 3 .

Example: An agricultural area has a small, deciduous, managed (low-level), woodland (gen.fdn) that borders a small residential area with two single-family homes (urs.sfh). During revision, these two areas each occupy less than 5 percent, but collectively occupy more than 5 percent of the area within $500 \mathrm{~m}$ of the well. Despite the fact that these two areas collectively occupy more than 5 percent of the area being characterized, they are distinctly different and cannot be combined. On the revised 500-m overlay, these two areas would be reclassified (recoded) "gen.mis." In addition, "general, miscellaneous" (gen.mis) for the 500--m area would be " $x$ ' $d$ " (see table 3, item 3, LULCFS) and "gen.fd" and "urs.sfh" would be listed (see table 3, item 3, LULCFS, for "500-m area"). In addition, "urs.sfh" could be considered a potential point source, and would be listed as an "other" occurrence (see table 4, item 4, LULCFS.) Given that this is the only occurrence of this potential source, the number of such occurrences (1) would be listed in table 4 as one, and the distance from this area to the well would be recorded in table 4 .

List of General Definitions and Codes

General land-use and cover categories are somewhat of an enigma because the current (1998) NAWQA Land-Use Studies primarily focus on agriculture, urban, or, to a lesser extent, mined, lands. In addition to these three categories, however, eight other land-use categories, including miscellaneous, are defined in order to characterize other land uses and covers that could occur in the vicinity of a LUS well (table.B4).

\section{Urban Land Use and Cover}

To begin landscape characterization with this section, the targeted land use should be urban (primarily commercial and residential), or this should at least be the predominant land use in the vicinity of the well. Other (general, agricultural, or mining) land-use categories, however, could be needed to complete the landscape characterization. (If one of these other categories best describes the area in the vicinity of the well, begin the characterization with that category, and only return to this section if necessary.)

\section{Use of Urban Definitions and Codes}

Please follow the steps below to ensure complete and consistent characterization of urban lands within either $50 \mathrm{~m}, 500 \mathrm{~m}$, or the optional area of the well:

(1) Please read through this entire section at least once, including the remaining steps below, the example classifications, and the definitions and codes for urban lands.

(2) For each urban land area to be classified, select the appropriate urban code from the List of Urban Definitions and Codes Section (below), as follows:

(a) Select the appropriate urban category from either commercial ( 6 subcategories), residential ( 3 subcategories), or other (5 subcategories);

(b) Within this category, choose the subcategory (definition and code) that best describes the urban land use and cover.

(3) Use the code for this land use and cover on the original 50-m grid or 500-m (or optional-area) overlay to identify the area and all other areas with similar land use and cover.

(4) For each area identified, add either an I (irrigated) or NI (not irrigated) to the end of the code on the grid or overlay, followed by either $N D$ (no enhanced drainage), $\boldsymbol{E S}$ (enhanced drainage to surface flow), $\boldsymbol{E} \boldsymbol{G}$ (enhanced drainage to ground-water recharge), or $\boldsymbol{E S G}$ (enhanced drainage to surface flow and groundwater recharge). ${ }^{21}$ (See LULCFS, Appendix A, table 3, item 3, Heading for examples).

(5) Repeat step (2) through step (4) above until all urban land uses and covers have been identified and coded on the original grid or transparent overlay (s).

21. An unlined earth ditch enhances drainage, and water drained could contribute to ground-water recharge or surface-water flow. Drainage into an earthen retention pond generally enhances ground-water recharge, but seldom contributes to surface-water flow. Finally, a pipe or cement-lined drain generally contributes to surface-water flow but not to ground-water recharge. 
Table B4. General land use and cover definitions by categories and codes for

\section{Land-Use Study Wells ${ }^{a}$}

\begin{tabular}{|c|c|c|c|}
\hline CATEGORY & SUBCATEGORY & CODES & COMMENTS \\
\hline \multirow[t]{2}{*}{ RANGE LAND } & $\begin{array}{l}\text { Grassland } \\
\text { Tree and shrub }\end{array}$ & $\begin{array}{l}\text { gen.rgr } \\
\text { gen.rts }\end{array}$ & $\begin{array}{l}\text { Refers to open lands, mainly found in the west, that historically were part of the open range. } \\
\text { Consider distinct from pasture to high-density livestock areas, such as feedlots. (See } \\
\text { livestock, under "Agriculture Definitions and Codes"). }\end{array}$ \\
\hline & Mix of above & gen.rmx & \\
\hline \multirow[t]{6}{*}{ FOREST LAND } & $\begin{array}{l}\text { Deciduous, } \\
\text { unmanaged or } \\
\text { low intensity }\end{array}$ & gen.fdn & $\begin{array}{l}\text { Forested lands that are distinct from (a) landscape production (see agriculture, crop codes, } \\
\text { landscape), (b) pasture land containing trees, but primarily covered with forage for } \\
\text { livestock (see agriculture, cropcodes, livestock), (c) city or residential parks (see urban, } \\
\text { recreational, parks, basic), or (d) Palustrine wetlands (see WETLANDS below). } \\
\text { Unmanaged or managed at low intensity implies protected Federal, State, or private } \\
\text { wilderness, old-growth, or natural areas, as well as parks, watershed and other } \\
\text { reservoir-protection areas, or long-term forest growth areas. Intensively managed often } \\
\text { implies private monoculture areas (tree farms) for short-term silviculture where trees often } \\
\text { are uniform in age and spacing with little or no unmanaged understory vegetation. Used } \\
\text { for press-board, chip, pulp, or ornamental (christmas) tree production. }\end{array}$ \\
\hline & $\begin{array}{l}\text { Deciduous, } \\
\text { intensively } \\
\text { managed }\end{array}$ & gen.fdm & \\
\hline & $\begin{array}{l}\text { Coniferous, } \\
\text { unmanaged or } \\
\text { low intensity }\end{array}$ & gen.fcn & \\
\hline & $\begin{array}{l}\text { Coniferous, } \\
\text { intensively } \\
\text { managed }\end{array}$ & gen.fcm & \\
\hline & $\begin{array}{l}\text { Mixed, } \\
\text { unmanaged or } \\
\text { low intensity }\end{array}$ & gen.fmn & \\
\hline & $\begin{array}{l}\text { Mixed, } \\
\text { intensively } \\
\text { managed }\end{array}$ & gen.fdm & \\
\hline \multirow[t]{3}{*}{ WATER } & Open & gen.wat & $\begin{array}{l}\text { For open water, include natural or arificial ponds, lakes, reservoirs, rivers, streams, estuaries } \\
\text { bays, and oceans. To be distinguished from WETLANDS (below), and from areas } \\
\text { designed to hold or store runoff from urban areas, or wastewaters from production or } \\
\text { processing (for example, storm retention or detention, irrigation-return-flow, sewage, or }\end{array}$ \\
\hline & & & tailing lagoons or ponds, which are considered under targeted land uses. ${ }^{a}$ \\
\hline & $\begin{array}{l}\text { Perennial ice or } \\
\text { snow }\end{array}$ & gen.soi & \\
\hline WETLAND & Palustrine & gen.wpl & $\begin{array}{l}\text { Include artificial, as well as natural, areas but only if former are not designed chiefly for } \\
\text { waste-water treatment--for example, urban storm-retention or tertiary sewage treatment, } \\
\text { which are considered under urban land use and cover definitions and codes. These wetland } \\
\text { subcategories are defined by Cowardin and others (1979). Use of a mixed wetland } \\
\text { subcategory implies two or more wetland types have been combined, most likely because } \\
\text { one or both occupy less than } 5 \text { percent of the area being characterized. For any } \\
\text { combination the individual wetland subcategories are listed in comments line across from } \\
\text { the listing of gen.wmx in table } 3 \text { item } 3 \text { of the Land-Use and Land-Cover Field Sheet } \\
\text { (Appendix A). }\end{array}$ \\
\hline
\end{tabular}


Table B4. General land use and cover definitions by categories and codes for Land-Use Study Wells ${ }^{a}$--Continued

\begin{tabular}{|c|c|c|c|}
\hline CATEGORY & SUBCATEGORY & CODES & COMMENTS \\
\hline \multirow{5}{*}{$\begin{array}{l}\text { WETLAND-- } \\
\text { Continued }\end{array}$} & Lacustrine & gen.wlc & . \\
\hline & Riverine & gen.wrv & \\
\hline & Estuarine & gen.wes & \\
\hline & Marine & gen.wmr & \\
\hline & Mixed & gen.wmx & \\
\hline TUNDRA & None & gen.tun & Include alpine areas. \\
\hline BARREN LAND & None & gen.brl & $\begin{array}{l}\text { Exposed lands including rocks, dunes, or beaches that lack vegetative cover because of } \\
\text { natural processes--volcanic, climatic, eolian, or pyrrhic events. Distinguish from land } \\
\text { temporarily made barren by development--construction, plowing, blasting, mining, or } \\
\text { overgrazing, which is described under targeted land uses. }\end{array}$ \\
\hline $\begin{array}{l}\text { GENERAL, } \\
\text { MISCEL- } \\
\text { LANEOUS }\end{array}$ & None & gen.mis & $\begin{array}{l}\text { Includes any area initially defined in relation to a major category or subcategory above, or } \\
\text { under targeted land uses } s^{2} \text {, but found to occupy less than } 5 \text { percent of the area being } \\
\text { characterized. List each land use and cover by code that is placed in this subcategory in } \\
\text { relation to area being characterized at bottom of table } 3 \text { item } 3 \text { of LULCFS. }\end{array}$ \\
\hline
\end{tabular}

a. Urban, agricultural, and mined lands are considered targeted land uses, and definitions and codes for each appear as separate sections in this appendix.

(6) Apply the 5-percent rule, and revise the grid or overlay for each urban land use and cover identified accordingly. During field classification, any land use and cover, regardless of its areal extent, can be defined and coded on the original 50-m grid, or 500-m (or optional-area) overlay. During the revision, to remain uniquely defined, the total area of a particular land use and cover must equal at least 5 percent of the area being classified. Urban land uses and covers with areas that do not equal at least 5 percent are redefined as follows:

(a) Rename any residential (urban-category I) or commercial (urban category II) area on the revised 50-m grid or 500-m (or optional-area) overlay as "urban, miscellaneous" (urb.mis). Replace the original land use and cover name and code with urban, miscellaneous (urb.mis), and re-list the original code across from this urban in the "Sources and Comments" column of table 3 , item
3, Appendix A). Relabel the area (s) in question on the $50-\mathrm{m}$ grid or overlay (s) in a similar fashion.

(b) Rename any urban barren and vacant lands, or urban land with abandoned buildings, whose total area is not at least 5 percent of the area being characterized as "general miscellaneous" (gen.mis). Use an " $x$ " to designate those areas being classified where the revised code applies (in the narrow columns of table 3, item 3, Appendix A). Record the original codes incorporated into gen.mis (at bottom of table 3, item 3 of Appendix A) in relation to the area being characterized.

Ultimately, the revision step implies that only two classifications under urban can have total land areas that possibly occupy less than 5 percent of the area being classified and still be listed following all revisions. These are "urban, miscellaneous" and "general, miscellaneous." 
Example: Within $500 \mathrm{~m}$ of a well there are a series of retail commercial enterprises along a single street (including a gas station, a dry cleaner, several fast-food restaurants, a drug store, and two grocery stores). Most of these enterprises have their own off-street entrances and parking. This commercial area is an "(urban) commercial strip, with retail sales and services (ucs.mix)." Its boundaries include the buildings, and the adjacent landscaping, parking, interior-access roads, and the street they abut. Also suppose the landscapes are irrigated, but runoff goes to storm sewers that transport runoff to the river nearby (which unpiles the code is ucs.rss.I.ES). Then "ucs.rss.I.ES" appears on the original 500-m overlay for this area. In addition, "urban commercial strip, (ucs.mix)" is listed in table 3 item 3, Appendix A, and across from this listing there is an " $x$ " in the narrow column that corresponds to the 500-m buffer, an " $I$ " in the irrigation column, and an "ES" in the drainageenhancement column. Finally, the gas station and the dry cleaners (where they actually use dry-cleaning solvents) are noted as potential point sources (table 4, item 4, Appendix A).

Example: Suppose the area within $500 \mathrm{~m}$ of the well contains, among other things, three different types of streets--one-way two-lane roads, twoway two-lane roads, and a major freeway, where the latter clearly occupies 5 percent or more of the 500-m area. In addition, suppose the secondary roads join a commercial center of office buildings with several commercial strips, where these commercial areas all have parking lots drained by storm sewers that lead to a nearby river, with no landscaped areas. In this case, only two or three land-use and cover definitions and codes are needed to classify all of the above. These would be a major freeway (urw.aut.NI.ES), a commercial center (ucc.mix.NI.ES), and the strips (ucs.mix.NI.ES). Each would include all adjacent parking areas and secondary roadways. Potential point sources within each area would need to be identified.

Example: Suppose within $500 \mathrm{~m}$ of a well, one encounters a commercial strip which on either side has a combination of different residential structures (for example, large townhouses and unattached, single-family homes). Collectively each residential area exceeds 5 percent of the area within $500 \mathrm{~m}$ of the well. These areas could be considered "residential, mixed (urs.mix)". The boundaries for "urs.mix" would include the actual residences, and the adjacent landscape--lawns, driveways, and sidewalks--down to and including any small street they abut. These residential areas are irrigated (urs.mix.I) and drainage runs from to a sediment-detention (earthen) impoundment that allows collected runoff to evaporate or seep into the ground (urs.mix.I.EG). The code "urs.mix.I.EG" would be used to identify each of these residential areas. "Urban residential mix (urs.mix) would be listed (see table 3 item 3 , LULCFS), an " $x$ " would be placed in the column that corresponded to the area being classified in which this land use and cover exceeded 5 percent, and if this check appeared in relation to the $500-\mathrm{m}$ area, an " $I$ " would be placed in the Irrigation column, and an "ES" in the drainage-enhancement column (across from this land use and cover in the appropriate columns table 3 , item 3 ). In addition, the sediment detention recharge pond would be noted as a potential point source (table 4 , item 4, Appendix A).

Example: Within $500 \mathrm{~m}$ of the well and adjacent to a commercial strip lies an access road and alongside it a freeway. Characterization of this freeway, which includes the access road and right of way landscape is as an "(Urban) right of way, automotive" (urw.aut). Its closest proximity to the well also would be noted (table 4, item 4, "Urban" section, Right of Ways). Drainage enhancement takes road runoff through grass-lined ditches to a large, shallow, low-flow, earthern, sediment and runoff retention pond, but large flows often appear to spill from this pond directly into a nearby river, which implies the code for this freeway would be "urw.aut.NI.ESG". The pond also is considered as a "right of way--other: retention pond in commercial setting"

(urw.dep.NI.ESG), and, its occurrence and distance from the well recorded as a potential point source (table 4, item 4, "Urban" section, Right-of-Ways). During revision, if the freeway area was at least 5 percent of the area within $500 \mathrm{~m}$ of the well, but the pond area was not, the pond could be incorporated into "urw.aut" and its unique presence and distance from the well noted (see "Urban" section, table 4 , item 4). On the other hand, if the pond area equaled or exceeded 5 percent, then codes for these two types of areas would remain on the revised 500-m overlay, the definitions and 
related codes would appear as separate items (table 3, item 3, Appendix A), as would their potential as point sources (table 4 , item 4 , Appendix A).

List of Urban Definitions and Codes

Because NAWQA urban studies target recent residential and commercial developments, and avoid heavy industrial areas, the urban land-use and cover codes reflect this (table B5)--mainly being residential, commercial, or other. The "other" category identifies urban types of land use and cover that appear in residential and commercial areas, but that are not typical suburban residential or commercial properties. Thus, this category includes areas classified as light and heavy industrial, airports, amusement parks, and sport complexes.

As noted in the examples, an urban (sub) category has within its aerial boundary more than just the structural extent of the building (s). For a residential or commercial property adjacent related landscape features should be included (such as garages, parking areas, private drives, sidewalks, curbs, drainage ways and ditches). For roadway areas such as a freeway, the road itself, entrance and exit ramps, shoulders, drainage works (ditches, retention ponds, etc), and the right-of-way land beyond the actual road structure are all included.

If similar urban land uses abut one another, combine them into one larger area. Thus, a group of single-family, unattached residential homes and landscapes, including residential streets, are mapped as a single entity (urs.sfh) with one continuous boundary around this area.

\section{Agricultural Land Use and Cover}

To begin landscape characterization with this section, the targeted land use should be agriculture (primarily row crop or pasture), or it should at least be the predominant land use in the vicinity of the well. Other (general, urban, or mining) land-use categories, however, could be needed to complete the landscape characterization. (If one of these other categories best describes the area in the vicinity of the well, begin the characterization with that category, and only return to this section if necessary.)
Use of Agricultural Definitions and Codes

To ensure complete and consistent characterization of agricultural land use within either $50 \mathrm{~m}, 500 \mathrm{~m}$, or the optional area of the well, follow the steps below:

(1) Read through this entire section at least once, including the remaining steps below, the examples, the definitions and codes for nonproductive land, or productive land with unknown crop or livestock, and the definitions of known agricultural land use and cover.

(2) For each agriculturally-related area, identify the appropriate land use and cover. Select either one of the mixed or miscellaneous subcategories (see List of Agricultural Definitions and Codes--(A), (B), or (C) below), or, if the area is covered with a known crop or livestock then proceed as follows:

(a) select the appropriate agricultural category; and from that category, a crop name; (b) identify the cover for that crop from those described at the end of the category from which the crop name was obtained, and (c) use the Name and Cover chosen to create the NAME.COVER code. This code generally is expressed as xxx.yyy", where $x x x$ is a three-letter Name code and yyy is a three-letter Cover code which are separated by a period.

(3) Use the NAME.COVER code on the original 50-m grid or 500-m (or optional-area) overlay to identify this area, and all other similar areas, within the area being characterized.

(4) If applicable, add either an I (irrigated) or NI (not irrigated) to the end of each code identified on the grid or overlay, followed by either an ND (no enhanced drainage), $\boldsymbol{E S}$ (enhanced drainage to surface flow), $\boldsymbol{E} \boldsymbol{G}$ (enhanced drainage to ground water recharge), or $\boldsymbol{E S G}$ (enhanced drainage to surface and ground water). 


\section{Table B5. Urban (chiefly residential and commercial) land use and cover definitions by categories and codes for Land-Use Study wells}

\begin{tabular}{|c|c|c|c|}
\hline CATEGORY $^{\text {a }}$ & SUBCATEGORY & CODE & COMMENTS \\
\hline \multirow[t]{7}{*}{ RESIDENTIAL } & $\begin{array}{l}\text { Single-family housing, unattached, } \\
\text { with contiguous properties }\end{array}$ & urs.sfh & Typical suburban one-family one-residence development. \\
\hline & $\begin{array}{l}\text { Multi-family housing, } \\
\text { semi-attached, with contiguous } \\
\text { properties }\end{array}$ & urs.mfs & $\begin{array}{l}\text { Multi-family single-residence units, separated and adjacent to one } \\
\text { another--duplexes, fourplexes, rowhouses, and condominiums. }\end{array}$ \\
\hline & $\begin{array}{l}\text { Multi-family housing, attached, } \\
\text { complex, often a single structure }\end{array}$ & urs.mfc & $\begin{array}{l}\text { Multi-story apartment building or high-rise, solo, or in combination with } \\
\text { other similar types of residences. }\end{array}$ \\
\hline & $\begin{array}{l}\text { Mobile homes, unattached, with } \\
\text { contiguous properties }\end{array}$ & urs.mob & $\begin{array}{l}\text { Regardless of whether mobile homes are mobile or have been rendered } \\
\text { immobile. }\end{array}$ \\
\hline & $\begin{array}{l}\text { Other residential housing, requires } \\
\text { specification and new code }\end{array}$ & uxs.xxx & $\begin{array}{l}\text { Housing other than that above, where " } x \text { " terms require definition, and use of } \\
\text { code requires approval. }\end{array}$ \\
\hline & Mixed residential housing & urs.mix & $\begin{array}{l}\text { Include any of the above that occupy less than } 5 \text { percent of the area being } \\
\text { classified. }\end{array}$ \\
\hline & . & & \\
\hline \multirow[t]{3}{*}{ COMMERCIAL } & Strip & ucs.mix & $\begin{array}{l}\text { Includes commercial and retail sale or service shops, stores, and outlets with } \\
\text { generally independent access and parking along or off street }\end{array}$ \\
\hline & Center & ucc.mix & $\begin{array}{l}\text { Similar to above, but attached, multilevel, and often with limited-access, } \\
\text { centralized parking. Examples: shopping centers, malls, and office parks. }\end{array}$ \\
\hline & Mixed & ucm.mix & Retail sales and services, combination of strip and center. \\
\hline \multirow[t]{10}{*}{ OTHER } & $\begin{array}{l}\text { Social and community services } \\
\text { Health and related services }\end{array}$ & uss.hao & Hospitals and other health facilities, fire, and police stations. \\
\hline & Education and related services & uss.eao & $\begin{array}{l}\text { Primary or secondary schools, universities, academies, libraries, museums, } \\
\text { science centers, and aquariums. }\end{array}$ \\
\hline & Cemetery & uss.cem & Private or public place of interment. \\
\hline & Recreation parks, basic & urc.pkb & $\begin{array}{l}\text { Residential and city, mainly non-structural, little to modest development } \\
\text { (confined mainly along access road), mostly open grass or forest land. }\end{array}$ \\
\hline & Parks and complexes & urc.pkd & $\begin{array}{l}\text { Developed to highly developed theme or amusement parks, golf courses, and } \\
\text { outdoor sports fields and complexes. }\end{array}$ \\
\hline & Right-of-Ways & & \\
\hline & Automotive ${ }^{b}$ & urw.aut & $\begin{array}{l}\text { Major corridors (three or more single lanes)--freeways, highways, and } \\
\text { beltways, or arterial streets. Include median, shoulder, and drainage } \\
\text { adjacent to road boundary (fenceline, if present). }\end{array}$ \\
\hline & Railroad & urw.rxr & $\begin{array}{l}\text { Include tracks, bed, drainage, yards, station, outbuildings, and land to } \\
\text { railroad boundary (fenceline if present). }\end{array}$ \\
\hline & Airline & urw.air & $\begin{array}{l}\text { Include runways, approaches, drainage, buildings, and land to the airport } \\
\text { boundary (fenceline, if present). }\end{array}$ \\
\hline & Water (sea) ports & w.wat & $\begin{array}{l}\text { Include docks, boat ramps, buildings of port adjacent to water to port } \\
\text { boundary (fenceline, if present). }\end{array}$ \\
\hline
\end{tabular}


Table B5. Urban (chiefly residential and commercial) land use and cover definitions by categories and codes for Land-Use Study wells--Continued

\begin{tabular}{llll}
\hline CATEGORY & SUBCATEGORY & CODE & COMMENTS \\
\hline $\begin{array}{c}\text { OTHER-- } \\
\text { Continued }\end{array}$ & Utilities & urw.utl & $\begin{array}{l}\text { For water, sewer, electrical, gas, oil, or other pipelines, with major right-of- } \\
\text { way dimensions. Also include facilities for above (such as pump or } \\
\text { substations, treatment plants, and storage buildings to boundary (fenceline, } \\
\text { if present). }\end{array}$ \\
\end{tabular}

Industrial Construction

$\begin{array}{ll}\text { Light } & \text { uic.lht } \\ \text { Heavy } & \text { uic.hvy }\end{array}$

Development of a single residential or commercial lot.

Development of major commercial, residential, or industrial centers (convert one land use to another), or installation of major services; for example. utilities or transportation, including buried telephone or electrical lines, storm sewers, new or expanded highways, bridges, or light rail facilities).

Manufacturing

\section{Light}

Heavy

Waste Management

\begin{tabular}{|c|c|}
\hline Recycling, clean materials & uiw.rcm \\
\hline Recycling, scrap & uiw.rim \\
\hline Disposal, incineration & uiw.inc \\
\hline Disposal, landfill, clean material & uiw.lcm \\
\hline $\begin{array}{l}\text { Disposal, landfill, commercial or } \\
\text { industrial material }\end{array}$ & uiw.lim \\
\hline Sewage, treatment only & uiw.swo \\
\hline $\begin{array}{l}\text { Sewage treatment with } \\
\text { storm sewers }\end{array}$ & uiw.sws \\
\hline arren and vacant lands & \\
\hline $\begin{array}{l}\text { Urban commercial or residential, } \\
\text { barren without buildings }\end{array}$ & ucr.brn \\
\hline $\begin{array}{l}\text { Urban commercial or residential, } \\
\text { vacant with abandon buildings }\end{array}$ & ucr.abn \\
\hline $\begin{array}{l}\text { code, see "New Codes" section, } \\
\text { this appendix.) }\end{array}$ & \\
\hline
\end{tabular}

uim.lht
Industrial areas or parks that provide assembly, packaging. storage, and/or distribution of already manufactured parts or goods. Industrial areas or parks that refine and process raw materials, transport raw materials, or utilize raw materials, to produce goods.

uim.hvy Includes plastic, glass, metals, cardboard, and paper. Industrial, manufacturing, and commercial materials (junkyards).

Little to no commercial or industrial waste.

Includes most commercial or industrial waste.

Little to no commercial or industrial waste.

Includes commercial and industrial waste.

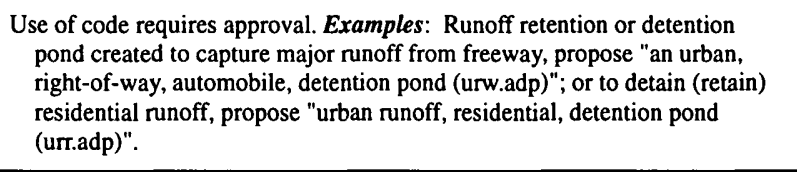

2. Urban land use and cover also could require identification as potential point source (Appendix A: table 4, item 4, December 1997 Land-Use and LandCover Field Sheet.

b. Roads, in particular those with two or more lanes are included in a given land use and cover, or serve as boundary between two land uses. Also treated as potential point sources. 
(5) Repeat steps (2) through (4) above for each different land use and cover until all agricultural and other area (s) have been identified and coded on the original grid or transparent overlay (s).

(6) Apply the 5-percent rule. Revise grid or overlay (in office) for each agricultural land use and cover identified. During field classification, any land use and cover, regardless of areal extent, can be defined and coded on the original 50-m grid, or 500-m (or optional) overlay. During the revision, to remain uniquely defined, the total area of each identified land use must cover at least 5 percent of the area being characterized. If this is not the case, revise agriculturally-related land uses as follows:

(a) Rename crop (livestock)-producing areas on the revised $50-\mathrm{m}$ grid or $500-\mathrm{m}$ (or optional) overlay as cropland, miscellaneous (crl.mis). (Include in this category barren cropland (crl.brn) if the total area of barren land does not equal at least 5 percent).

(b) Rename non-crop (or livestock)producing areas on the revised $50-\mathrm{m}$ grid or 500-m (or optional) overlay as general, miscellaneous (gen.mis). (Include in this category cropland, nonproductive (crl.npd) and/or agricultural-related infrastructure development (ard.mis) if either of these do not have total areas that are at least 5 percent of the area being characterized.

(c) Depending on whether cropland, miscellaneous or general, miscellaneous are used on the grid or an overlay, proceed as follows to revise the Appendix A:

If cropland, miscellaneous (crl.mis) is used, erase the original land-use and cover definition, and replace it with cropland, miscellaneous (crl.mis)-- (column 1, table 3, item 3, Appendix A). List the original (erased) land-use and cover code across from cropland, miscellaneous (cri.mis) in the "Source and Comments Column" of table 3, item 3. If general, miscellaneous (gen.mis) is used, place an " $x$ " across from this definition and code (which always appears in table 3 ) in the narrow column that corresponds to the area being characterized. Erase the original land- use and cover definition and code, and rewrite it after the general miscellaneous (bottom of table 3, item 3 , Appendix A) in relation to the area being characterized.

Ultimately, completion of the revision implies that for all agricultural areas encountered within the area being classified, only two can have total land areas that possibly occupy less than 5 percent of the area being classified-cropland, miscellaneous or general, miscellaneous. All others agriculturally-related listings must occupy at least 5 percent of the area being classified.

\section{Rotational Crops or Intercropping}

If crop area is used for rotational cropping, identify the area in a manner similar to that described in the first example but on the basis of the crop grown in relation to when water-quality samples were collected at the well. In addition, indicate rotation is used and also list the appropriate crop NAME.COVER code (s) of the other crop (s) grown in the rotation (across from where the crop above is listed in the "Additional Comments" column, table 3, item 3, Appendix A). If intercropping is used (more than one crop growing in the field), simply pick one crop to identify the field, and indicate that intercropping is used, and also list the appropriate crop NAME.COVER code (s) of the other intercrop (s) grown in the field (across from where the crop above is listed in the "Additional Comments" table 3, item 3, Appendix A). Be sure that for each code listed it is noted whether or not irrigation or drainage enhancement occur.

Example-Single Crop: Within $500 \mathrm{~m}$ of the well there are irrigated fields of sweet corn in rows with drainage enhancement through earth ditches to a nearby stream. From the "vegetables" category comes the listing, "corn, sweet (crs)" (crop NAME). At the end of the "Vegetables" category, is the appropriate COVER designation, "row cover (rwc)". The Name.Cover Code is "crs.rwc", to which I is added an for irrigated, and "ESG" for enhanced drainage to surface flow and ground-water recharge. The code "crs.rwc.I.ESG" is used to identify all areas within $50 \mathrm{~m}, 500 \mathrm{~m}$, or the optional area (on the original $50-\mathrm{m}$ grid or the 500-m (or optional) overlay for this type of 
cropped area. During revision, and field acreage is at least 5 percent of the $500-\mathrm{m}$ area, so "corn, sweet (crs.rwc.I.ESG)" remains on the revised 500-moverlay, and on the Appendix A (listed on a line in column 1, table 3, item 3 , Appendix A; with an " $x$ " placed in the narrow column for the 500-m buffer, and an "I" and "ESG" in their respective irrigation and drainage columns and across from this listing in table 3).

Example: Several areas of nonirrigated row corn with no enhanced drainage are seen, but the purpose for which the corn is grown is unknown. Under the vegetable category, "corn, unknown" (cru) is selected as the crop NAME. The correct COVER for this crop is "row cover" $(\boldsymbol{r w c})$. The NAME.COVER code, with management practices is

"cru.rwc.NI.ND". Suppose during revision, the areal extent of this corn is less than 5 percent of the area within $500 \mathrm{~m}$ of the well. Fields within this area are recoded on the $500-\mathrm{m}$ overlay as cropland, miscellaneous (crl.mis). The original listing (cru.rwc.NI.ND) is erased and replaced by Cropland, miscellaneous (crl.mis) (column 1, table 3, item 3, Appendix A). The original code (cru.rwc.NI.ND) is rewritten across from the cropland, miscellaneous listing (Additional Comments column, table 3, item 3, Appendix A).

List of Agricultural Definitions and Codes

If the identity of the crop or livestock being grown at the time water-quality samples are collected is known, use the known crop list (table B6) to identify it and obtain the NAME.COVER code. If the land appears nonproductive, or its productivity is unknown, select the most appropriate category from those listed (table B7) to identify the land and code.

\section{Mining Land Use and Cover}

To begin landscape characterization with this section, the targeted land use should be mining (includes active, abandon, or reclaimed), or this should at least be the predominant land use in the vicinity of the well. Other (general, urban, or agricultural) land-use categories, however, could be needed to complete the landscape characterization. (If one of these other categories best describes the area in the vicinity of the well, and they do not reflect reclaimed mined lands, begin the characterization with that category, and only return to this section as necessary.)

Use of Mining Definitions and Codes

To ensure complete and consistent characterization of mined or mined and reclaimed land within either $50 \mathrm{~m}, 500 \mathrm{~m}$, or the optional area of the well, follow the steps:

(1) Read through this entire section at least once, including the remaining steps below, the examples, and the list of definitions and codes for mined lands.

(2) For each land area to be classified, select the appropriate mining code from the List of Mining Definitions and Codes (below), as follows:

(a) Under category $I$, identify possibly active or abandoned mine-related features by code as needed on the original 50-m grid or 500-m (or optional-area) overlay. If applicable, add either $N D$ (no enhanced drainage), $\boldsymbol{E S}$ (enhanced drainage to surface flow), $\boldsymbol{E} \boldsymbol{G}$ (enhanced drainage to ground-water recharge), or $\boldsymbol{E S G}$ (enhanced drainage to surface flow and ground-water recharge). (For example, some areas of mine could be pumped to reduce groundwater elevation. This could affect recharge, and because the pumped water is often dumped, surface runoff. In this case, ESG should be used.)

(b) Under category II, reclaimed land, identify these features in relation to their historical mine feature and their current land use and cover by code as needed on the original $50-\mathrm{m}$ grid or $500-\mathrm{m}$ or optional overlay area. Codes for reclaimed lands are 12 letters in length, and of form aaa.bbb.ccc.ddd. If applicable, add either an $I$ (if irrigated) or $N I$ (not irrigated) to the end of the code(s) on the original grid or overlay, followed by either an $N D$ (no enhanced drainage), $\boldsymbol{E S}$ (enhanced drainage to surface flow) $\boldsymbol{E} \boldsymbol{G}$ (enhanced drainage to ground-water recharge), or $\boldsymbol{E S G}$ (enhanced drainage to surface flow and ground-water recharge). (For examples, see Appendix A, item 3, table 3-Heading.) 
Table B6. Subcategories of land use and cover for agricultural lands with known livestock or crop

\begin{tabular}{|c|c|c|c|}
\hline CATEGORYa & SUBCATEGORY & NAME & COVER (S) \\
\hline \multirow[t]{28}{*}{ FRUITS AND NUTS } & Fruits; tree varieties & Apples (apl) & Orchard (orc) $)^{b}$ \\
\hline & & Apricots (apr) & Grove (grv) \\
\hline & & Avocados (avc) & \\
\hline & & Cherries, sweet, (chs) & \\
\hline & & Cherries, tart (cht) & \\
\hline & & $\begin{array}{l}\text { Citrus (cit)--includes grapefruit, lemons, } \\
\text { limes, oranges, tangelos, or tangerines }\end{array}$ & \\
\hline & & Dates (dts) & \\
\hline & & Figs (fgs) & \\
\hline & & Nectarines (nct) & \\
\hline & & Olives (olv) & \\
\hline & & Peaches (pch) & \\
\hline & & Pears (prs) & \\
\hline & & Persimmons (prm) & \\
\hline & & Plums and prunes (plp) & \\
\hline & & Pomegranates (pmg) & \\
\hline & $\begin{array}{l}\text { Fruits; shrub or herbaceous } \\
\text { varieties }\end{array}$ & Blackberries and raspberries (brb) & Row cover (rwc) \\
\hline & & Blueberries (bbu) & Patch cover (ptc) \\
\hline & & Cranberries (cra) & Bedded cover (bdc) \\
\hline & & Strawberries (stb) & Ground cover (gre) \\
\hline & & $\begin{array}{l}\text { Berries, other (bot)--includes boysenberries } \\
\text { and loganberries }\end{array}$ & \\
\hline & & Mixed berries (bmx)-- two or more of above & \\
\hline & & Cantaloupes (cnt) & \\
\hline & & Honeydew melons (hyd) & \\
\hline & & Watermelon (wtm) & \\
\hline & & Melons, other (meo) & \\
\hline & & $\begin{array}{l}\text { Melons, mixed (mmx)-- two or more of } \\
\text { above }\end{array}$ & \\
\hline & & $\begin{array}{l}\text { Grapes, dried (gpr)-- includes raisins or } \\
\text { currants }\end{array}$ & \\
\hline & & Grapes fresh juice or fruit (gpf) & \\
\hline
\end{tabular}


Table B6. Subcategories of land use and cover for agricultural lands with known livestock or crop--Continued

\begin{tabular}{|c|c|c|c|}
\hline CATEGORY ${ }^{\mathrm{a}}$ & SUBCATEGORY & NAME & COVER (S) \\
\hline \multirow[t]{6}{*}{$\begin{array}{l}\text { FRUITS AND NUTS-- } \\
\text { Continued }\end{array}$} & $\begin{array}{l}\text { Fruits; shrub or herbaceous } \\
\text { varieties--Continued }\end{array}$ & Grapes, spirits (gps) & (see previous page, Fruits, shrubs) \\
\hline & Nuts; tree varieties & Almonds (nlm) & Orchard (orc) \\
\hline & & Filberts or hazelnuts (nfh) & Grove (grv) \\
\hline & & Pecans (npe) & \\
\hline & & Pistachios (nps) & \\
\hline & & Walnuts (nwl) & \\
\hline \multirow[t]{24}{*}{ VEGETABLES } & $\begin{array}{l}\text { Field crops, mainly fresh, } \\
\text { herbaceous, and shrub varieties }\end{array}$ & Artichokes (art) & Row cover (rwc) \\
\hline & & Asparagus (asp) & Patch cover (ptc) \\
\hline & & Beans, unknown (bnn) & Bedded cover (bdc) \\
\hline & & Beans, fresh, green, lima or snap (bfv) & Ground cover (grc) \\
\hline & & $\begin{array}{l}\text { Beans, dry, (bdv)--include lima, lentil, } \\
\text { mung, pinto, kidney }\end{array}$ & \\
\hline & & Beets, edible--fresh or processed (bte). & \\
\hline & & Beets, sugar only (bts) & \\
\hline & & Broccoli (brc) & \\
\hline & & Brussel Sprouts (bsp) & \\
\hline & & Cabbage, chinese (cbc) & \\
\hline & & Cabbage, head (cbh) & \\
\hline & & Cabbage, mustard (cbm) & \\
\hline & & Carrots (car) & \\
\hline & & Cauliflower (cal) & \\
\hline & & Celery (cel) & \\
\hline & & Chicory (chc) & \\
\hline & & Collards (cld) & \\
\hline & & Corn, unknown use (cru) & \\
\hline & & Corn, sweet only (crs) & v \\
\hline & . & $\begin{array}{l}\text { Corn--all, except sweet, for feed or } \\
\text { silage (crf) }\end{array}$ & \\
\hline & & Cucumbers and pickles (ccp) & \\
\hline & & Herb or Spice, unknown (hsu) & \\
\hline & & Herb or Spice, Garlic (hga) & \\
\hline & & Herb or spice, Ginger (hgi) & \\
\hline
\end{tabular}


Table B6. Subcategories of land use and cover for agricultural lands with known livestock or crop--Continued

\begin{tabular}{|c|c|c|c|}
\hline CATEGORY ${ }^{\mathrm{a}}$ & SUBCATEGORY & NAME & COVER (S) \\
\hline \multirow[t]{26}{*}{$\begin{array}{l}\text { VEGETABLES-- } \\
\text { Continued }\end{array}$} & $\begin{array}{l}\text { Field crops, mainly fresh, } \\
\text { herbaceous and shrub }\end{array}$ & & (see previous page, VEGETABLES) \\
\hline & varieties & Herb or spice, Hops (hps) & \\
\hline & & Herb or spice, Mint (hmt) & \\
\hline & & Herb or spice, Mustard seed (hms) & \\
\hline & & Herb or spice, Parsley (hpa) & \\
\hline & & Herb or spice, all other, fresh (hmf) & \\
\hline & & Herb or spice, all other, dried (hmd) & \\
\hline & & $\begin{array}{l}\text { Lettuce or watercress (Itw)--any variety, } \\
\text { includes Iceberg, Romaine, Boston, or Bib }\end{array}$ & \\
\hline & & Peanuts (pnt) & \\
\hline & & Okra (okr) & \\
\hline & & Onions, unknown (onu) & \\
\hline & & $\begin{array}{l}\text { Onions, dry (ond), any variety--includes } \\
\text { Vidalia and Yellow }\end{array}$ & \\
\hline & & $\begin{array}{l}\text { Onions, green (ong), any variety--includes } \\
\text { chives and endives }\end{array}$ & \\
\hline & & Peas, unknown use (psu) & \\
\hline & & $\begin{array}{l}\text { Peas, dry (psd), any variety--includes } \\
\text { cowpeas, southern, and chickpeas }\end{array}$ & \\
\hline & & Peas, green (psg), chinese or other varieties & \\
\hline & & Peppers, hot (pph) & \\
\hline & & Peppers, sweet (pps) & \\
\hline & & Potatoes, sweet (pts)-- include yams & \\
\hline & & $\begin{array}{l}\text { Potatoes, other varieties (pto)--includes Irish, } \\
\text { Idaho, and Russet }\end{array}$ & \\
\hline & & Radishes (rds) & \\
\hline & & Spinach (sph) & \\
\hline & & $\begin{array}{l}\text { Squash or pumpkins, dry, edible (sqd)--for } \\
\text { ornamentals see below }\end{array}$ & \\
\hline & & Squash, green, fresh, edible (sqg) & \\
\hline & & Tomatoes (tmt) & \\
\hline & & Turnips, greens or tubers (tur) & \\
\hline
\end{tabular}


Table B6. Subcategories of land use and cover for agricultural lands with known livestock or crop--Continued

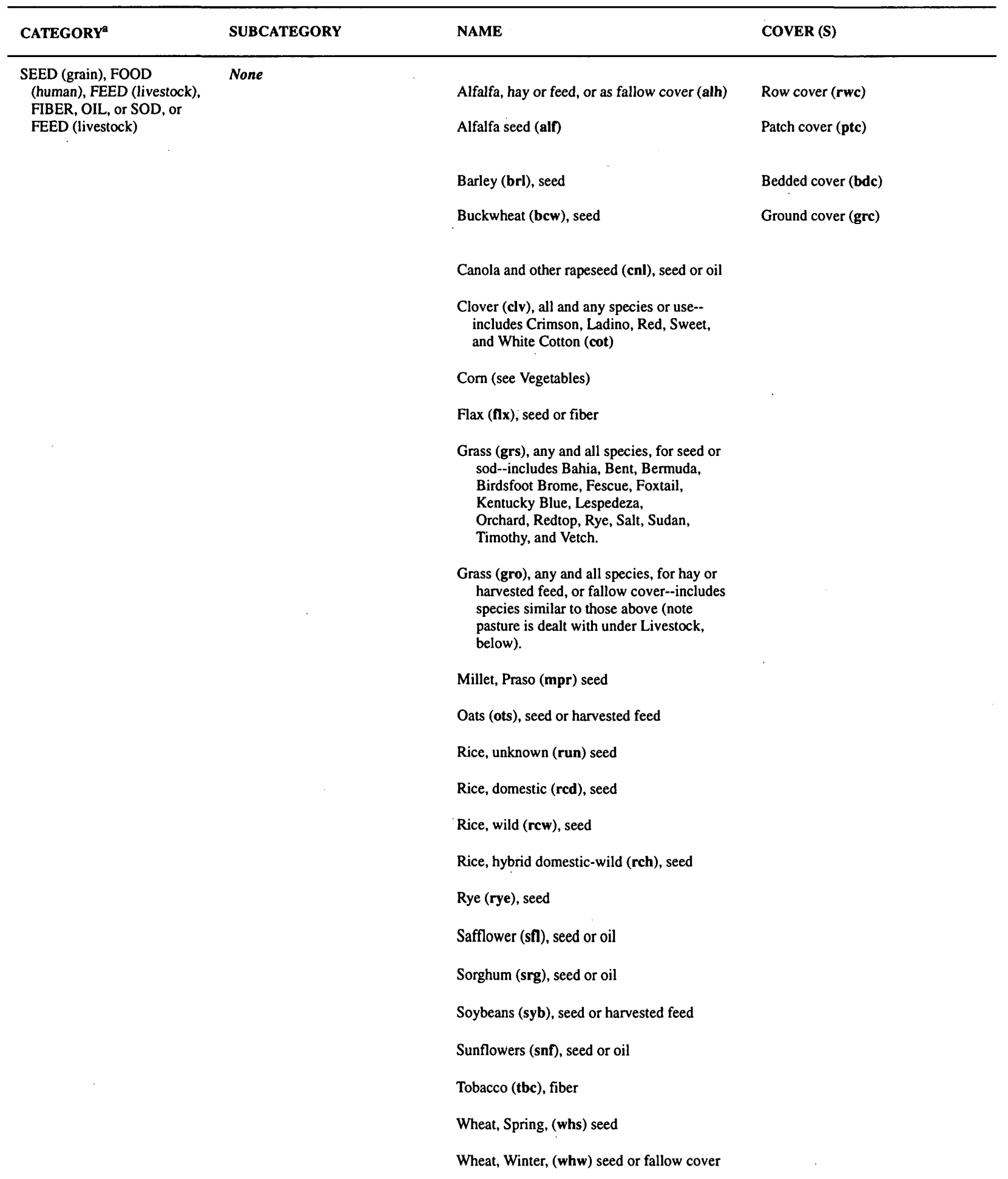


Table B6. Subcategories of land use and cover for agricultural lands with known livestock or crop--Continued

\begin{tabular}{|c|c|c|c|}
\hline CATEGORY ${ }^{\mathrm{a}}$ & SUBCATEGORY & NAME & COVER (S) \\
\hline \multirow[t]{10}{*}{$\begin{array}{l}\text { ORNAMENTAL AND } \\
\text { AQUACULTURE }\end{array}$} & $\begin{array}{l}\text { Ornamentals; includes nursery } \\
\text { and landscape }\end{array}$ & $\begin{array}{l}\text { Dry landscape ornamentals (lad)--includes } \\
\text { flowers, squashes, and gourds }\end{array}$ & $\begin{array}{l}\text { If mainly indoors or covered, and } \\
\text { potted or planted (ipp) }\end{array}$ \\
\hline & & $\begin{array}{l}\text { Fresh landscape ornamentals(laf); or } \\
\text { if large fresh areas of individual types then: }\end{array}$ & $\begin{array}{l}\text { If mainly outdoors and potted or } \\
\text { planted (opp) }\end{array}$ \\
\hline & & Low ground cover (lag) & $\begin{array}{l}\text { If about equally indoors and } \\
\text { outdoors (bpp) }\end{array}$ \\
\hline & & Grasses, flowers, or shrubs, (lah) & \\
\hline & & Trees (lat) & . \\
\hline & & Mix of above (lam) & \\
\hline & Food crops; includes aquaculture & Single food crop (la?) ${ }^{c}$ & $\begin{array}{l}\text { If mainly indoors or covered, } \\
\text { irrigated (ini) }\end{array}$ \\
\hline & & Mixed food crops (laf) & $\begin{array}{l}\text { If mainly indoors or covered, } \\
\text { aquaculture (iaq) }\end{array}$ \\
\hline & & & $\begin{array}{l}\text { If mainly outdoors or uncovered, } \\
\text { irrigated (odi) }\end{array}$ \\
\hline & & & $\begin{array}{l}\text { If mainly outdoors or uncovered, } \\
\text { aquaculture (oaq) }\end{array}$ \\
\hline \multirow[t]{12}{*}{$\begin{array}{l}\text { LIVESTOCK }{ }^{d} \text {-.Domestic } \\
\text { and Wild Species }\end{array}$} & Domestic & Cattle, beef (lcb) & Range (rng) \\
\hline & & Cattle, dairy (lcd) & Pasture (pst) \\
\hline & & Horses (lhr) & Feedlot (fdl) \\
\hline & & Llamas (lla) & $\begin{array}{l}\text { Confined (cfn)--includes sheds, } \\
\text { pens, corrals and coops }\end{array}$ \\
\hline & & $\begin{array}{l}\text { Poultry, eggs, (lpe) domestic fowl--includes } \\
\text { chickens, turkeys, and ostrich }\end{array}$ & \\
\hline & & Poultry, hatchlings (lph), domestic fowl & \\
\hline & . & $\begin{array}{l}\text { Poultry, birds (lpb), juvenile and adult-- } \\
\text { includes broilers, fryers, roasters }\end{array}$ & \\
\hline & & Sheep and Goats, domestic (lsg) & \\
\hline & & Swine, domestic (lsd) & \\
\hline & & Livestock, domestic, mixed (ldm) & \\
\hline & Wild & $\begin{array}{l}\text { Livestock, non-domestic (wild), single } \\
\text { species }(l \mathrm{wx})^{\mathrm{c}} \text {, requires unique approved } \\
\text { code }\end{array}$ & \\
\hline & & $\begin{array}{l}\text { Livestock, non-domestic (wild), } \\
\text { mixed (lwm)-- includes game farms }\end{array}$ & \\
\hline
\end{tabular}


Table B6. Subcategories of land use and cover for agricultural lands with known livestock or crop--Continued

\begin{tabular}{|c|c|c|c|}
\hline CATEGORYa & SUBCATEGORY & NAME & COVER (S) \\
\hline \multirow[t]{15}{*}{$\begin{array}{l}\text { TROPICALS--Includes } \\
\text { tree, herbaceous, and } \\
\text { shrub varieties }\end{array}$} & None & Bananas, use unknown (bnu) & Row cover (rwc) \\
\hline & & Bananas, sweet (bns) & Patch cover (ptc) \\
\hline & & Bananas, plantain (bnp) & Bedded cover (bdc) \\
\hline & & Coffee (ncf) & Ground cover (grc) \\
\hline & & Guavas (gvs) & \\
\hline & & Kiwifruit (kwf) & Tree varieties: \\
\hline & & Kumquats (kmq) & Orchard (orc) \\
\hline & & Lotus root (Itr) & Grove (grv) \\
\hline & & Macadamia nuts (nmc) & \\
\hline & & Mangoes (mng) & \\
\hline & & Papayas (ppy) & \\
\hline & & Passion fruit (pfr) & \\
\hline & & Pineapples (pnp) & \\
\hline & & Sugarcane (sgc) & \\
\hline & & Taro (tar) & \\
\hline
\end{tabular}

a. For each crop (or livestock) area to be identified, note the appropriate (sub) category from among those listed, and within that subcategory identify crop name, appropriate cover, and, then code.

b. Use orchard if moderately to intensely cultivated; otherwise use grove.

c. Select appropriate last letter for single crop, code must be unique and approved (see New Codes Section of this Appendix for further discussion).

d. Primary use of land is to raise livestock, not crops, including food for livestock.

(3) Apply the 5-percent rule. Revise grid or overlay (in office) for each identified mined land use. During field classification, any land use and cover, regardless of areal extent, can be defined and coded on the original 50-m grid, or 500-m (or optional) overlay. During the revision, to remain uniquely defined, the total area of each identified land use must cover at least 5 percent of the area being characterized. If this is not the case, revise mine-related land uses as follows:

(a) Rename mine-related areas on the revised 50-m grid or 500-m (or optional) overlay as either mining, miscellaneous (min.mis) or, if land is reclaimed, as reclamation, miscellaneous (rcm.mis). 
Table B7. Subcategories for agricultural lands that are nonproductive or whose productivity is unknown

\begin{tabular}{|c|c|c|}
\hline SUBCATEGORY a & CODE & COMMENTS \\
\hline $\begin{array}{l}\text { NAME: Cropland (crl) } \\
\text { COVER: non-productive (npd) }\end{array}$ & crl.npd & $\begin{array}{l}\text { Fallow, set-aside, or abandoned agricultural land which could be covered with mixed } \\
\text { native grasses, weeds, or brush. During revision, if the total area of this land use and } \\
\text { cover is less than } 5 \text { percent of the area being characterized, reclassify as General, } \\
\text { miscellaneous (see text for further discussion). }\end{array}$ \\
\hline $\begin{array}{l}\text { NAME: Cropland (crl) } \\
\text { COVER: barren (bm) }\end{array}$ & crl.brn & $\begin{array}{l}\text { Cultivated (recently tilled), but lacks sufficient vegetative residue to identify crop. } \\
\text { During revision, if the total area of this land use and cover is less than } 5 \text { percent of } \\
\text { the area being characterized, reclassify as Cropland, miscellaneous (see text for } \\
\text { further discussion). }\end{array}$ \\
\hline $\begin{array}{l}\text { NAME: Agricultural infrastructure } \\
\text { development (ard) } \\
\text { COVER: miscellaneous (mis) }\end{array}$ & ard.mis & $\begin{array}{l}\text { Lands related to agriculture, that do not directly produce crops or livestock, but possibly } \\
\text { could affect ground-water quality, and, except perhaps for the } 50 \text {-m area, consist of } \\
\text { individual features that often will cover less than } 5 \text { percent of the } 500-\mathrm{m} \text { buffer or } \\
\text { optional area. Include in this category areas occupied by the farm residence, other } \\
\text { farm-related structures (fuel tanks, bams, silos, grain elevators, chemical, farm- } \\
\text { implement, and other storage sheds or maintenance areas), and any interconnecting } \\
\text { roadways and non-productive terrain among these features. Also include isolated retail, } \\
\text { single-farm operations such as a roadside market and parking area. All of these features } \\
\text { can (but need not) be individually identified on the original } 50 \text {-m grid or } 500-\mathrm{m} \text { (or/ } \\
\text { optional) overlay. Some features, for example, fuel tanks, septic systems, or other } \\
\text { potential count sources of contamination should be individually listed. During } \\
\text { revision, if the total area of this land use and cover is less than } 5 \text { percent of area being } \\
\text { characterized, reclassify as General, miscellaneous (see text for further discussion). }\end{array}$ \\
\hline
\end{tabular}

a. Nonproductive lands or lands whose productivity is unknown are defined as lands that appear either (a) to be in fallow, set-aside, or abandon, or (b) to be cropped, but when observed areas literally are barren. Crop identification is to be in relation to that growing at time water-quality samples were collected at well in area being characterized. If this information is unavailable because of timing of site visit, Study-Unit teams should consult land owners in the field, or their local U. S. Department of Agriculture, CFSA office. In the event that crop type (s) cannot be established, but it is obvious that a crop was growneither because of visual observations in the field, through interviews, or historical data (such as that from the local USDA-CFSA office), then the land should be classified as Cropland, barren (crl.brn), which implies the land is productive, but what is grown is unknown.

(b) Erase the original land-use and cover definition (s) replaced by either mining, miscellaneous (min.mis) or reclamation miscellaneous (rcm.mis), and list the latter in column 1 , table 3 , item 3 , of Appendix A). Re-list the original (erased) land-use and cover definition (s) by code across from mining, miscellaneous (min.mis) or reclamation miscellaneous (rcm.mis) in the "Source and Comments"column of table 3, item 3.
Ultimately, step (3) implies only two mining classifications can have total land areas that possibly occupy less than 5 percent of the area being classified and still be listed after the revisions above: mining, miscellaneous and reclamation, miscellaneous. All others listed must occupy at least 5 percent of the area being classified. 


\section{List of Mining Definitions and Codes}

Identification of visible mine-related and reclamation-related characteristics differentiates between abandoned (and not reclaimed), actively mined, and reclaimed mined lands (table B8). For each mine-related land use in the area being characterized, determine its status in relation to these three subcategories, and then select the definition in that subcategory that best describes the landscape. If a mine-related land use appears that is not listed, a new definition and code can be derived (see New or Revised Definitions and Codes, in this appendix).

Example: Landscape is a terrace of overburden material reclaimed to deciduous long-term growth forest similar to that found adjacent to the mined area. According to the rules, this reclaimed area during mining is designated as "Overburden, terrace (min.oum)". Given it is reclaimed, it is redesignated as "Reclaimed overburden (mrc.oum)", and given it is deciduous forest cover (long-term growth), the land is defined as "Reclaimed overburden, forested, deciduous, long-term growth (mrc.oum.gen.fdn)".
Example: A flooded sedimentation pond is presumably reclaimed to create a palustrine wetland. It originally would have been designated as a flooded (assumed) sedimentation pond (min.psf)". Under reclamation, it is a "reclaimed sedimentation pond (mrc.psf), and reclaimed as a palustrine wetland (gen.wpl). The final land-use and cover designation is "Reclaimed sedimentation pond as Palustrine Wetland (mrc.psf.gen.wpl)". 
Table B8. Categories and subcategories of land use and cover for visible mining landscape features

\begin{tabular}{|c|c|c|}
\hline CATEGORY ${ }^{\mathrm{a}}$ & SUBCATEGORY & CODE \\
\hline \multirow{24}{*}{$\begin{array}{l}\text { ACTIVE OR ABANDON } \\
\text { MINE AREAS }\end{array}$} & Resource Extraction Areas Or Points ${ }^{c}$ & \\
\hline & Addit(s) or Shaft(s), Open, dry & $\min$. aod \\
\hline & Open, partially or fully flooded & min.aff \\
\hline & Filled, collapsed or backfilled, dry & min.aof \\
\hline & Filled, collapsed or backfilled, partially or fully flooded & min.afd \\
\hline & Galleries and Columns (Room and Pillar). & \\
\hline & Open, dry & min.god \\
\hline & Open, partially or fully flooded & min.gof \\
\hline & Filled, Collapsed or backfilled, dry & min.gcd \\
\hline & Filled, Collapsed or backfilled, partially or fully flooded & min.gcf \\
\hline & Long--High Wall & \\
\hline & Intact & $\min . h w i$ \\
\hline & Collapsed & $\min . h w c$ \\
\hline & Long--Low Wall & \\
\hline & Intact & $\min .1 w i$ \\
\hline & Collapsed & $\min .1 w c$ \\
\hline & Pit or Quarry & \\
\hline & Open, dry & min.pod \\
\hline & Open, partially or fully flooded & min.pof \\
\hline & Collapsed or backfilled, dry & min.pfd \\
\hline & Collapsed or backfilled, partially or fully flooded & min.pff \\
\hline & Strip or Cut & \\
\hline & Open, dry & $\min . s o d$ \\
\hline & Open, partially or fully flooded & min.sof \\
\hline . & Collapsed or backfilled, dry & $\min . s f d$ \\
\hline & Collapsed or backfilled, partially or fully flooded & $\min . \mathrm{sff}$ \\
\hline & Drift & min.drf \\
\hline
\end{tabular}


Table B8. Categories and subcategories of land use and cover for visible mining landscape features--Continued

\begin{tabular}{|c|c|c|}
\hline CATEGORY ${ }^{\mathrm{a}}$ & SUBCATEGORY & CODE \\
\hline \multirow{23}{*}{$\begin{array}{l}\text { ACTIVE OR ABANDON } \\
\text { MINE AREAS }{ }^{\text {d-- }} \\
\text { Continued }\end{array}$} & Borehole (Natural gas or crude oil) & \\
\hline & Dry at surface & min.bhd \\
\hline & Flooded at surface & $\min . b h f$ \\
\hline & Extracted Materials and Processing Areas $\mathrm{e}$ & \\
\hline & $\begin{array}{l}\text { Resource Stockpiles--include not only stock--piles of resource, such as coal, } \\
\text { ore, gravel, stone, or block, but also storage facilities (e.g. tanks) for crude oil or } \\
\text { natural gas }\end{array}$ & min.rst \\
\hline & $\begin{array}{l}\text { Overburden--include other unprocessed but disturbed material, that is } \\
\text { removed to reach extractable resource, and dumped or deposited in piles } \\
\text { or terraces. }\end{array}$ & min.oum \\
\hline & $\begin{array}{l}\text { Tailings--includes processed materials that are dumped or deposited in } \\
\text { piles or terraces. }\end{array}$ & min.tpm \\
\hline & Processing Ponds Treatment & \\
\hline & Dry & min.ptd \\
\hline & Partially or fully flooded & min.ptf \\
\hline & Polishing & \\
\hline & Dry & min.ppd \\
\hline & Partially or fully flooded & min.ppf \\
\hline & Sedimentation & \\
\hline & Dry & min.psd \\
\hline & Partially or fully flooded & $\min . p s f$ \\
\hline & Unknown usage & \\
\hline & Dry & min.pud \\
\hline & Partially or fully flooded & min.puf \\
\hline & Other Infrastructure Features & \\
\hline & Buildings and structures & \\
\hline & Operational & $\min . b s o$ \\
\hline & Abandon & $\min \cdot b s a$ \\
\hline
\end{tabular}


Table B8. Categories and subcategories of land use and cover for visible mining landscape features--Continued

\begin{tabular}{lll}
\hline CATEGORY $^{\mathrm{a}}$ & SUBCATEGORY & CODE \\
\hline $\begin{array}{l}\text { ACTIVE OR ABANDON } \\
\text { MINE AREAS } \\
\text { Continued }\end{array}$ & Unknown usage--Continued & \\
& Refuse Dump & min.rdd \\
& Dry & min.rdf \\
& Partially or fully flooded & min.xxx \\
& Other, Specify ${ }^{\text {g }}$ & \\
Reclaimed Land & None & rcm.xxx.yyy.yyy (12-letter code $)^{\mathrm{i}}$ \\
\hline
\end{tabular}

a. Feature identified and conditions (open or filled, or dry or flooded) defined on basis of visible evidence or known information. Mined land use and cover also could require identification as potential point source (Appendix A: table 4, item 4, December-1997 Land-Use and Land-Cover Field Sheet.)

b. If an identified abandoned or active mining feature does not exceed 5 percent of the area being characterized, then it should be redefined as Mining miscellaneous (min.mis).

c. Roads, in particular, those with two or lanes are included in a given land use and cover, or serve as boundary between two land uses. Also treated as potential point sources.

d. If an identified abandoned or active mining feature does not exceed 5 percent of the area being characterized, then it should be redefined as Mining miscellaneous (min.mis).

e. Earth material moved, or removed, visible at the land surface, and not undergoing reclamation. (If area is being reclaimed, see Category II Reclaimed Land below).

f. If an identified abandoned or active mining feature does not exceed 5 percent of the area being characterized, then it should be redefined as Mining miscellaneous (min.mis).

g. See New Or Revised Definitions And Codes section in this Appendix.

h. If any identified reclaimed land use occupies less than 5 percent of the area being characterized, then it should be redefined as Reclamation, miscellaneous (mrc.mis).

1. The "xxx." part of the code is the last half of the code for the reclaimed mined feature, which is identified under the first category of this table; whereas the yyy.yyy is the reclaimed land use and cover code, which is identified under the general or other targeted land use and cover definitions presented earlier in this appendix. 


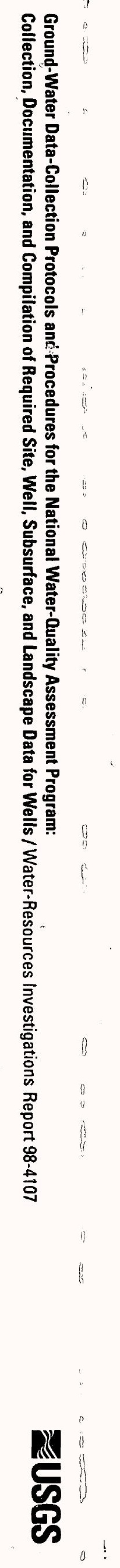

